\title{
Distribution, growth, selective feeding, and energy transformations of young-of-the-year blueback herring, Alosa aestivalis (Mitchill), in the James River, Virginia
}

Richard Greig Burbidge

College of William and Mary - Virginia Institute of Marine Science

Follow this and additional works at: https://scholarworks.wm.edu/etd

Part of the Marine Biology Commons, and the Oceanography Commons

\section{Recommended Citation}

Burbidge, Richard Greig, "Distribution, growth, selective feeding, and energy transformations of young-ofthe-year blueback herring, Alosa aestivalis (Mitchill), in the James River, Virginia" (1972). Dissertations, Theses, and Masters Projects. William \& Mary. Paper 1627407608.

https://doi.org/10.25773/8YFP-0829

This Dissertation is brought to you for free and open access by the Theses, Dissertations, \& Master Projects at W\&M ScholarWorks. It has been accepted for inclusion in Dissertations, Theses, and Masters Projects by an authorized administrator of W\&M ScholarWorks. For more information, please contact scholarworks@wm.edu. 
DISTRIBUTION, GROWTH， SELECTIVE FEEDING,

AND ENERGY TRANSEORMATTONS OF YOUNG-OF-THE-YEAR

BLUEBACK HERRING, ALOSA AESTIVALIS (MITCHILL), IN THE

JAMES RIVER, VIRGINIA

Richard Greig Burbidge

Kalamazoo, Michigan

B.A., Kalamazoo College, 1964

M.S., Michigan State University, 1957

A Dissertation Presented to the Graduate

Faculty of the Univensity of virginia

in Candidacy for the Degree of

Doctor of Philosophy

\author{
Department of Marine Science \\ University of Virginia
}

b

June 
This dissertation is submitted in partial fulfillment of the requirements for the degree of Doctor of Philosophy

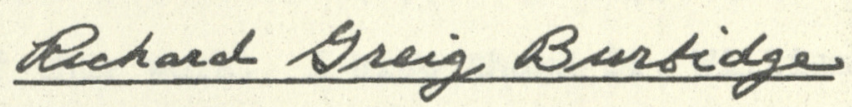
Richard Greig Burbidge

Approved, March 1972

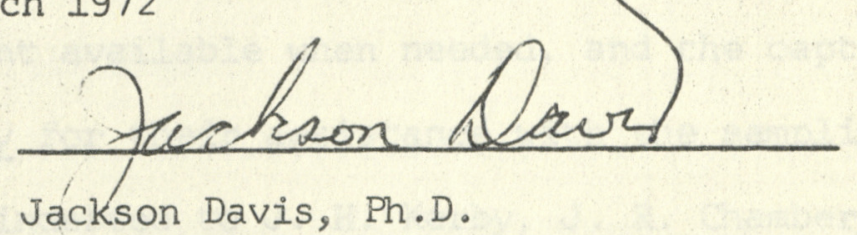
Jackson Davis, Ph.D.

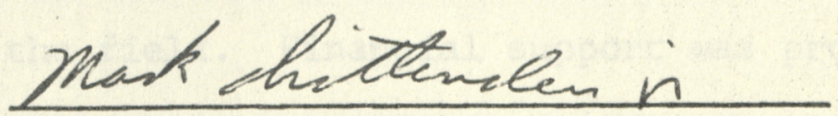
Mark E. Chittenden, Ph.D.

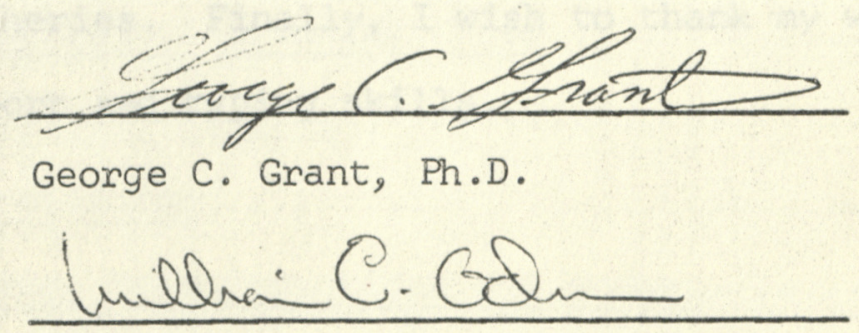

William E. Odum, Ph.D.

Department of Environmental Sciences 


\section{ACKNOWLEDGMENTS}

I would like to thank Dr. Jackson Davis for acting as my major professor, and Dr. M. E. Chittenden, Dr. G. C. Grant, and Dr. E. B. Joseph, Mr. J. J. Noreross, and Mr. E. P. Ruzecki for serving on my graduate committee. Their comments and suggestions improved the presentation of this work. I also thank Dr. William E. Odum for representing the Department of Environmental Sciences of the University of Virginia. I am grateful to J. E. Warinner and J. P. Miller for making equipment available when needed, and the captain and crew of the $R / V$ Langley for their assistance with the sampling program. I am especially indebted to J. H. Kerby, J.R. Chambers, and J. Bristow for helping in the field. Financial support was provided by Anadromous Fish Act (P. L. 89-304) funds through the Bureau of Comnercial Fisheries. Finally, I wish to thank my wife, Elena, for her moral support and typing skilis. 


\section{PABLE OF CONTENTS}

page

ACKNOWLEDGMENTS $\ldots \ldots \ldots \ldots \ldots \ldots \ldots \ldots \ldots \ldots \ldots \ldots \ldots \ldots \ldots \ldots \ldots$

LIST OE TABLES $\ldots \ldots \ldots \ldots \ldots \ldots \ldots \ldots \ldots \ldots \ldots \ldots \ldots \ldots$

LIST OF FIGURES $\ldots \ldots \ldots \ldots \ldots \ldots \ldots \ldots \ldots \ldots \ldots \ldots \ldots \ldots \ldots$

ABSTRACT ....................... ix

INTRODUCTION. ............................ 2

DESCRTPTION OE STUDY AREA ................... 4

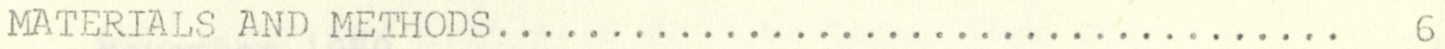

RESULTS. . . . . . . . . . . . . . . . . .

Temperature and Dissolved Oxygen............ 10

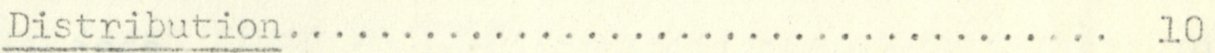

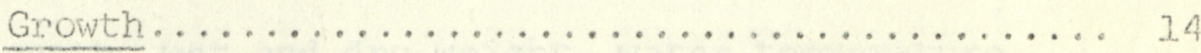

Zooplankton Standing Crops.............. 18

Selective Feeding...................... 24

Respination.............................

Energy Transfomations and Budget.......... 39

DISCUSSTON. ........................ 47

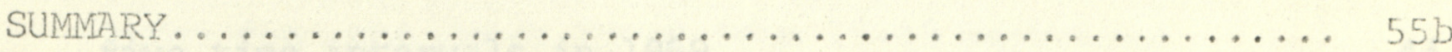

APPENDIX A: Zooplankton Standing Crops............ 56

APPENDTX B: Stomach Contents................. 87

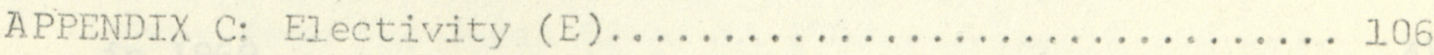

LITERATURE CITED...................... 25

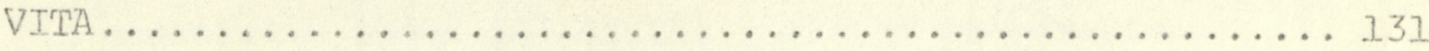




\section{LIST OF TABLES}

Table

page

1. Mean number of young-of-the-year blueback herring per 5 min tow with a 10 ft cobb trawl.

2. Mean fork length ( $\mathrm{mm}$ ) of young-of-the-year

blueback herring from the James River from June

through November 1969.

3. Mean weight $(\mathrm{g})$ of young-of-the-year blueback

herring from the James River from June through

November 1969.

4. Condition factor (K) of young-of-the-year blueback

herring from the James River from June through

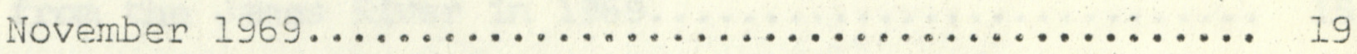

5. Fork Iength, wet and dry weight, water temperature,

and oxygen consumption rate for young-of-the-year

blueback herring from the James River............. 40

6. Growth rates ( $\mathrm{mm} / \mathrm{day}$ and $\mathrm{g} / \mathrm{day}$ ) and routine

metabolic rate $(g-c a l / f i s h / d a y)$ for young-of-the-

year blueback herring from the James River for

five time intervals in $1969 \ldots \ldots \ldots \ldots \ldots \ldots \ldots \ldots \ldots \ldots$

7. Energy transformations (per day) of a young-of-

the-year blueback herring for five time intervals

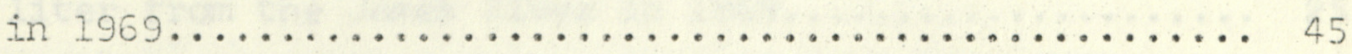




\section{LIST OF FIGURES}

Figure

page

1. Chart of the upper $2 / 3$ of the tidal portion of

the James River with sampling stations indicated...... 5

2. Schematic diagram of recording volumetric

respirometer............................

3. Temperature (C) and dissolved oxygen (mg/liter)

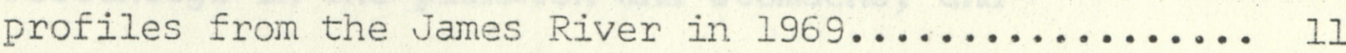

4. Mean number of young-of-the-year blueback herring

per 5 min tow with a $10 \mathrm{ft}$ cobb trawl from the

James River in $1969 \ldots \ldots \ldots \ldots \ldots \ldots \ldots \ldots \ldots \ldots \ldots \ldots$

5. Growth of young-of-the-year blueback herring

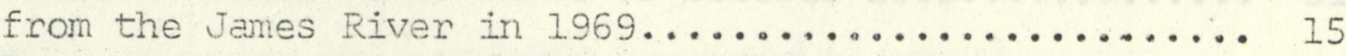

6. Condition factor (K) of young-of-the-year blueback

herring from the James River in $1969 \ldots \ldots \ldots \ldots \ldots \ldots$

7. Dominant zooplankton standing crops as number per

liter from the James Riven from 16-19 June to

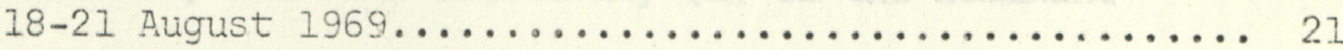

8. Dominant zooplankton standing crops as number per

liter from the Janes River from 16-19 September

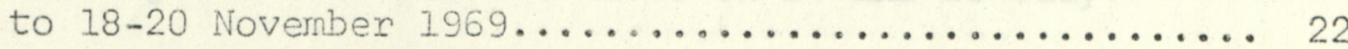

9. Total zooplankton standing crops as number per

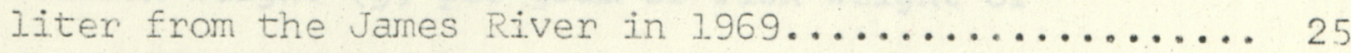

10. Percentage in the plankton and stomachs, and

electivity index (E) of the dominant zooplankton

from the James River on 16-19 June 1969.......... 27 
11. Percentage in the plankton and stomachs, and

electivity index (E) of the dominant zooplankton

from the James River on $14-17$ July $1969 \ldots \ldots \ldots \ldots \ldots \ldots$

12. Percentage in the plankton and stomachs, and

electivity index (E) of the dominant zooplankton

from the James River on $18-21$ August $1969 \ldots \ldots \ldots \ldots \ldots$

13. Percentage in the plankton and stomachs, and

electivity index (E) of the dominant zooplankton

from the James River on 17-19 September 1969........ 30

14. Percentage in the plankton and stomachs, and

electivity index (E) of the dominant zooplankton

from the James River on $28-30$ October $1969 . \ldots \ldots \ldots \ldots \ldots$. 31

15. Percentage in the plankton and stomachs, and

electivity index (E) of the dominant zooplankton

from the james River on 18-20 November 1969......... 32

16. Mean monthly percentage in the plankton and

stomachs, and mean electivity (E) of the dominant

zooplankton from the James River in 1969......... 33

17. Feeding periodicity of young-of-the-year blueback

herring from the Potomac River on 24 and 25 July

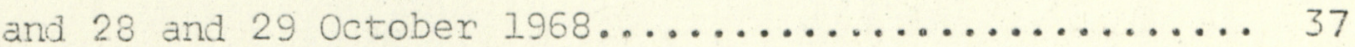

18. Stomach weight (g) per gram of fish weight of

young-of-the-year blueback herring from the James

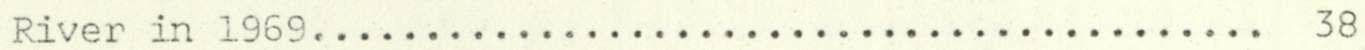


19. Regression of oxygen consumption ( $\mathrm{mg} \mathrm{O}_{2} /$ gram wet weight/hr) on temperature (C) for young-ofthe-year blueback herring.................. 41

20. Energy budget of a young-of-the-year blueback herring for a 155 day period in the James. River

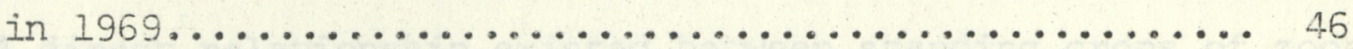




\section{ABSTRACT}

Energy transfomations and budget are computed for young-of-theyear blueback herring, Alosa aestivalis, in the James River, Virginia. Distribution, growth, and selective teeding are described.

Fish and zooplankton collections were made at five stations in the main channel of the James River from June through November 1969. Two $24 \mathrm{hr}$ series of samples were collected in July and October 1968 in the Potomac River.

A direct relationship existed between standing crops of zoopiankton and distribution, growth, and feeding of blueback herring. Zooplankton densities were highest upstream, where food consunption and growth rates were correspondingly highest. A progressive downstream decrease and upstrean increase in fish abundance occurred during the study. condition (K) decreased after flooding from Hurricane Camille.

Blueback herring fed primarily on copepods (Eurytemora affinis, Cycloos vernalis, and Canthocamptus robertcokeri), but cladocerans. (Bosmina longirostris-coregonj anc Diapnanosoma brachyurun) were also important. Selection (electivity) was strongest for adult copepods and weakest for copepod nauplii. Selection for copepodites and B. longirostris-coregoni was moderate to weak. Feeding occurred onI during daylight. Hect of predation on zooplankton populations is discussed.

Respiration experiments were carried out in the laboratory from November 1970 through March 1971. The regression of oxygen consumption on temperature (routine metabolism) was expressed as $\log 0=-1.4451+0.0548 \mathrm{~T}$, where $0=$ oxygen consumption (mg $\mathrm{O}_{2} /$ gram wet weight $/ \mathrm{hr}$ ), and $\mathrm{I}=$ temperature (C). 
DISTRIBUTION, GROWTH, SELECTIVE FEEDING,

AND ENERGY TRANSEORMATIONS OF YOUNG-OF-THE-YEAR

BLUEBACK HERRING, ALOSA AESTIVALIS (MTMCHILL), IN THE JAMES RIVER, VIRGINIA 


\section{INTRODUCTION}

Interest in ecological energetics has increased rapidly since Lindenan's (1942) paper on the trophic-dynamic aspect of ecology. Studies on energy transformations involved in growth (production), maintenance, and reproduction for a variety of aquatic and terrestrial species are reviewed by Slobodkin (1962), Englemann (1966), Phillipson (1.966), and Morowitz (1968). Collection of data on energy budgets, however, has progressed slowly and many budgets lack sufficient data (Cummins et a.l., 1969).

Annual budgets have been proposed for ecosystems (Juday, 1940; Odun, 1957; Teal, 1957, 1962; King and Ball, 1967), postions of ecosystems (Englemann, 1961; Mann, 1964), and single populations (Richnan, 1958; Cornita, 1964; Cummins et al., 1969).

Application of the energetic approach to fish has been a relatively recent development. Winberg (1956) provided the theoretical basis for study of energy transformations in natural populations, but comparable studies have appeared only recently (Mann, 1964, 1965; Davis and warren, 1965; Davies, 1963, 1964, 1966, 1967; Brocksen et al., 1968; Pandian, $1967 \mathrm{a}, 1967 \mathrm{~b}$; wissing, 1969).

The single population approach to ecosystem energetics will. eventually allow for model building at the ecosystem level. In the present study energy transfomations and budget are computed for youngof-the-year blueback herring, Alosa destivalis, in the James Rjver, Virginia. Distribution, growth rates, and feeding habits are described.

The anadromous blueback herring occurs from northern Florida to Nova Scotia (Bigelow and Schroeder, 1953), and spawns from late March 
through May at water temperatures from 21 to 24 C (Bigelow and Welsh, 1925). Transformation occurs at about $20 \mathrm{~mm}$ total length (Mansueti and Hardy, 1967), and young-of-the-year remain in the estuaries until fall before migrating to sea. Juvenjles remain in the Atlantic for 3 or 4 years before returning to spawn.

Little has been published on young-of-the-year bluebacks. Massmann (1953) and Massmann, Ladd, and McCutcheon (1952) discussed relative abundance in Virginia estuaries. Davis and Cheek (1966) described distribution, food habits, and growth in the cape Fear River System, North Carolina. Brooks (1968) and Brooks and Dodson (1965) considered prey size selection. Chittenden (1972) reported on salinity tolerance experiments. 


\section{DESCRIPTION OF STUDY AREA}

The James River (Figure I), the southernmost major tributary of the Chesapeake Bay, drains 10,000 square miles and flows 350 miles in a southeasterly direction from the Allegheny Mountains to the Chesapeake Bay at Hampton Roads (Walburg and Sykes, 1957).

The James is tidal from Hampton Roads to Richmond, a distance of 85 nautical miles. The average zone of saltwater intrusion extends 30 nautical miles upstream from the mouth. The transition $z$ one moves upstream and downstream as much as 15 miles with extremes in freshwater discharge. Mean freshwater discharge is about 7,500 cfs (Brehmer and Haltiwanger, 1966 ).

Phosphorous and nitrogen data indicate that the area extending 48 nautical miles downstream from Richmond is highly enriched. The City of Richmond and chemical industries in Hopewell are major contributors to nutrient enrichment (Brehmer and Haltiwanger, 1966).

Flooding occurred in the James Basin as a result of torrential rains from Hurricane Camille which fell on 19 to 20 August 1969 (U.S. Dept. Interion, 1969). Flow in the James at Cartersville, which is representative of flow into the James Estuary, averaged 20,400 cfs for the month; maximum daily flow (216,000 cfs) occurred on 21 August. 
Eigure 1. Chart of the upper $2 / 3$ of the tidal portion of the James Riven with sampling stations indicated. Station numbers are nautical miles from the river mouth. 


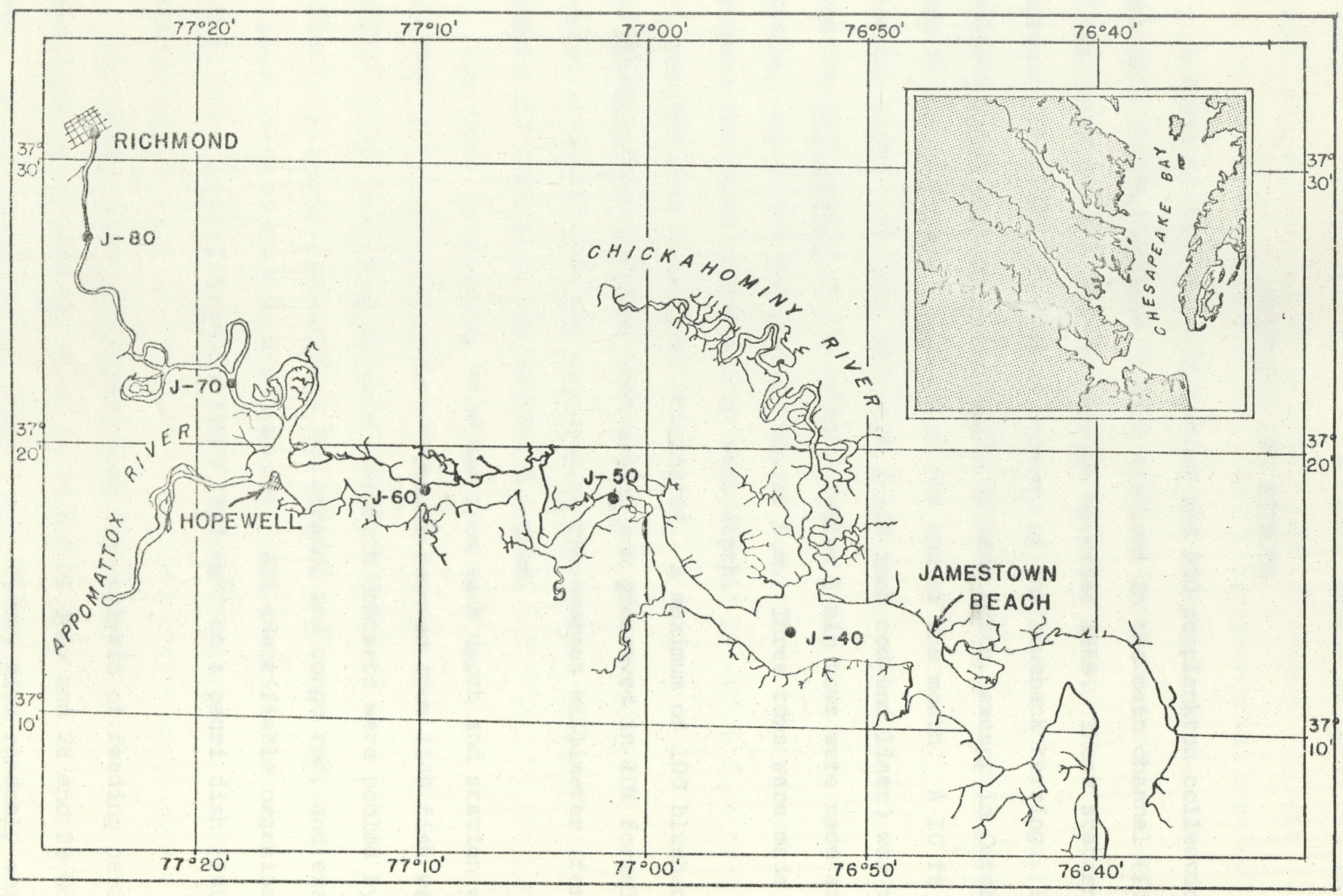




\section{MATERIALS AND METHODS}

A total of 360 fish collections and 200 zooplankton collections were made during daylight at five stations in the main channel (Figure I) of the James River from June through November 1969. These stations represent the tidal freshwater nursery of the blueback herring. Fish collections were made at the middle of each month, except in october when it was necessary to sample at the end of the month. A IO ft cobb midwater trawl ( $1 / 2$ inch mesh with a $1 / 8$ inch cod-end liner) was towed from the $\mathrm{R} / \mathrm{V}$ Langley at 5.6 knots. Twelve 5 min tows were made at each station, six at the surface and six at $5 \mathrm{~m}$. Three tows were made upstream and three downstream at each depth.

Catches were counted or subsampled. A maximum of 100 bluebacks was randomly selected from each sample and preserved in 10\% formalin. A total of 20,837 fish was measured to the nearest millimeter (fork length) and weighed to the nearest 0.1 gram.

The first 20 bluebacks examined from each depth and station were retained for stomach analysis. Stomachs removed from 1149 fish were weighed on an analytical balance. Stomach contents were pooled by station and depth, preserved in 95\% ethanol and congo red, and exanined in water under a dissecting microscope. A.l identifiable organisms within five randomly selected grids $\left(912 \mathrm{~mm}^{2}\right)$ on a petri dish $\left(5809 \mathrm{~mm}^{2}\right.$ ) were counted.

Two $24 \mathrm{hr}$ series of samples used for analysis of feeding periodicity were taken in the Potomac River on 24 and 25 July and 28 and 29 October 1968. Collections were made every 3 hr. Twenty fish randomly selected from 5 in samples were measured and weighed; stomachs were removed and 
weighed on an analytical balance. Stomach weight per gram of fish weight was computed to provide an estinate of stomach fullness.

Zooplankton samples from the James River were taken immediately after fish collections were made. A Clarke--Bumpus sampler with a \#2.0 mesh net ( $0.076 \mathrm{~mm}$ pore size) and a metering device was towed at 3.6 knots. Four 3 min tows were made at each station, two at the surface and two at $5 \mathrm{~m}$. Samples were also collected with a small boat at the end of each month (except october), towing speed being about 3.6 knots.

Collections were preserved in $95 \%$ ethanol and congo red. Each sample was diluted to $125 \mathrm{ml}$ and three $1 \mathrm{ml}$ subsamples were removed. Each subsample was placed in a gridded petri dish, diluted with a soap solution, and all organisms except Rotifera within five randomly selected grids were counted.

Water temperature was measured with a stem themometer and water samples were obtained with a Kemmerer sampler when fish and zooplankton collections were made. Dissolved oxygen was determined by the winkler method.

Fish used in respiration experiments were collected with a $100 \mathrm{ft}$ beach seine at Jamestown Beach from July through November 1970.

Experiments were carried out in the laboratory from November 1970 through March 1971. Routine metabolism was determined with a recording volumetric respirometer (Figure 2) modified from Wells and Warinner (1968). Gas entering the circuit at air stone connector B lifted water into equilibration chamben $C$ where dissolved respiratory gases were equilibrated with the gas phase. Oxygenated water returned to respination chamber A while the gas phase was drawn through flask D contain-ing a carbon dioxide absorbent (koI) and then recirculated. As oxygen 
Figure 2. Schematic diagram of recording volumetric respirometer. A, fish chamber; B, air stone connector (Halvin Products Co., Inc., Brooklyn, N.Y.); C, equijibration chamber; D, carbon dioxide absorbent (KOH) chamber; E, air pump (Silent Giant, Aquarium Pump Supply, Inc., Prescott, Arjzona); F, reconding spirometer (Model. 160, Custon Engineering and Development Co., St. Louis, Mo.); G, siphon tube used to fill fish chamber. 


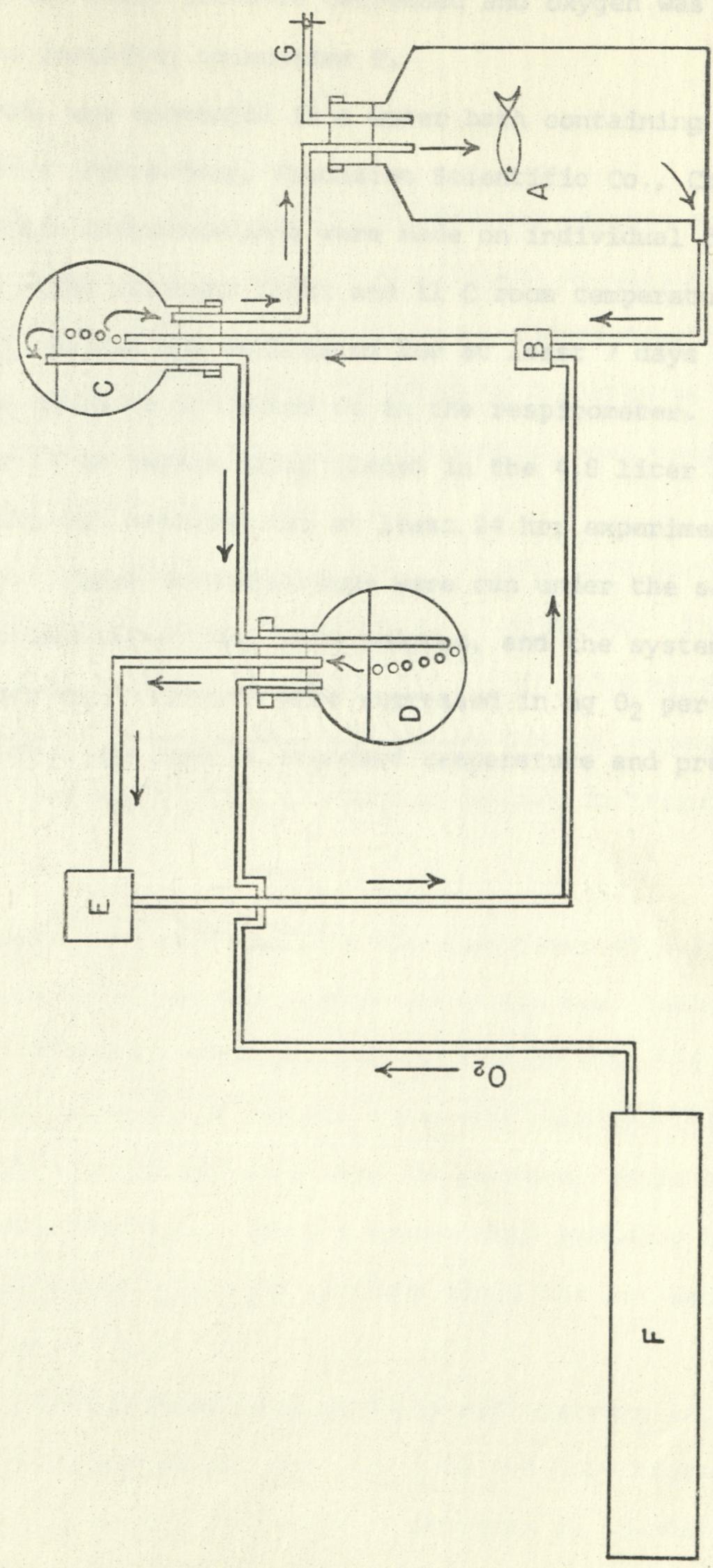


was consumed by the fish, pressure decreased and oxygen was added automatically by recording spirometer $F$.

The apparatus was submerged in a water bath containing a circulating heater (Porta-Temp, Precision Scientific co., Chicago, II1.). Respiration determinations were made on individual fish (from 16.4 to 28.7 C) under constant light and $I 1 \mathrm{C}$ room temperature. Fish were fed Artemia nauplii and acclimated for at least 7 days at the temperature they would be subjected to in the respirometer. They were then starved for $24 \mathrm{hr}$ before being placed in the 4.8 liter fish chamber. Oxygen consumption was measured for at least $24 \mathrm{hr}$; experiments ran from 24 to $91 \mathrm{hr}$. Blank determinations were run under the same experimental conditions after fish were removed, and the system was cleaned after each run. Results were expressed in $\mathrm{mg} \mathrm{O}_{2}$ per gram fish weight (wet and dry) per hour at standard temperature and pressure. 


\section{RESUITS}

Temperature and Dissolved oxygen

Temperature and dissolved oxygen differences between surface and $5 \mathrm{~m}$ in the James River were usually insignificant so values from both depths were averaged (Figure 3). A consistent temperature trend between stations was not apparent. Temperature differences during each sampling period were slight; maximum difference in mean temperature between stations for any period was $3.7 \mathrm{C}$.

Dissolved oxygen differences between stations were greater than temperature differences, but a pattern was not apparent. The range of individual values for the entire period was 2.0 to $10.0 \mathrm{mg} / \mathrm{lj}$ ter (25 to $100 \%$ saturation). The most obvious feature was an increase in dissolved oxygen associated with a seasonal decline in temperature.

\section{Distribution}

The total number of fish from the six tows taken at surface and $5 \mathrm{~m}$ was averaged to give the nean number per 5 min tow (Table 1 and Figure 4). More bluebacks were captured at surface than $5 \mathrm{~m}$ at every station and month. A total of 149,828 fish were captured over the entire perjod; 124,944 (83.4\%) came from the surface, while only $24,884(16.6 \%$ ) carne from $5 \mathrm{~m}$. The $5 \mathrm{~m}$ values were probably high since surface fish could have been captured while the net was being retrieved from $5 \mathrm{~m}$.

There was a general downstream decrease and upstream increase in the mean number of bluebacks per tow. In June and July highest numbers occurred at $\mathrm{J}-50$. In August there was an increase in abundance from J-40 to J-70. Fish were concentrated at J-60 in September (after 
Figure 3. Temperature (C) and dissolved oxygen (ng/liter) profiles from the James River in 1969. Solid line, temperature; broken line, dissolved oxygen. 


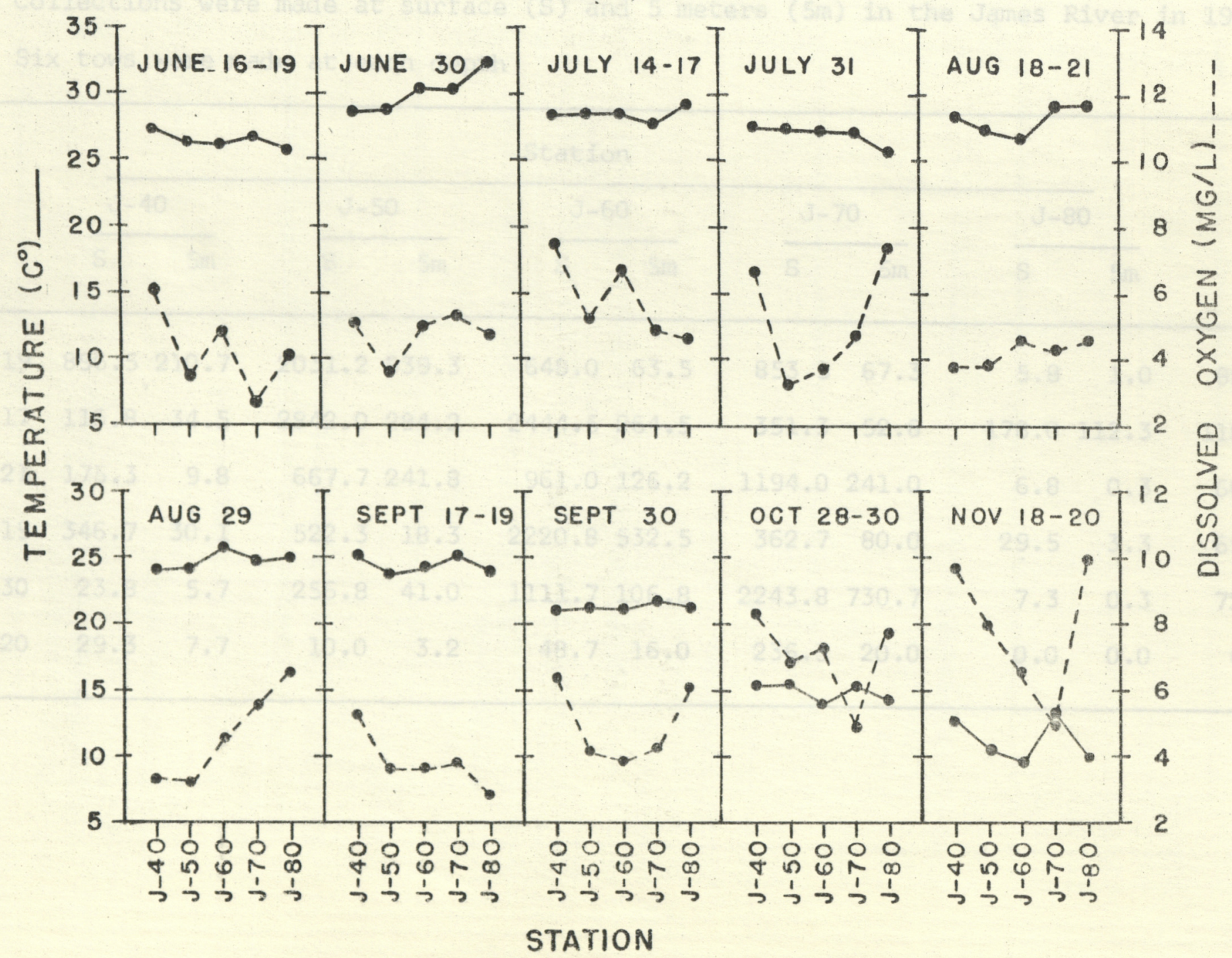


Table 1. Mean number of young-of-the-year blueback herring per 5 min tow with a 10 ft cobb trawl. Collections were made at surface (S) and 5 meters ( $5 \mathrm{~m}$ ) in the James River in 1969.

Six tows were made at each depth

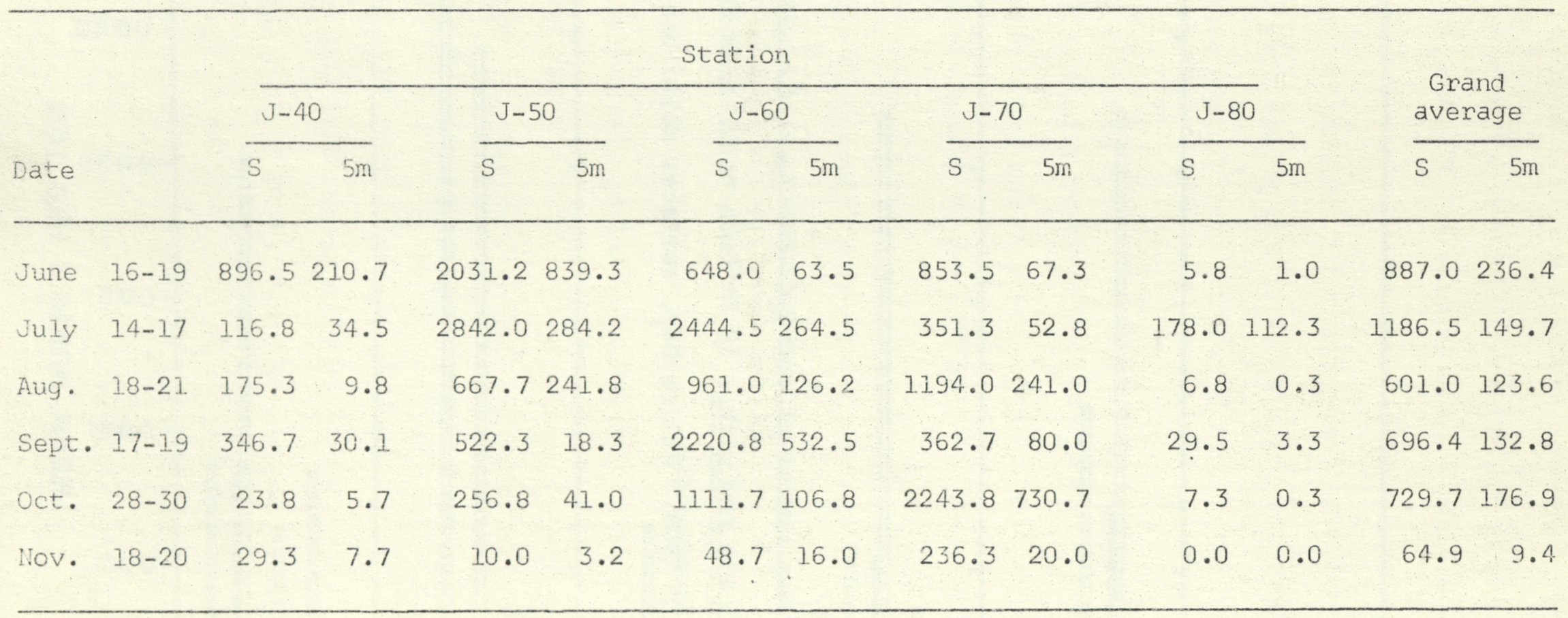


Figure 4. Mean number of young-of-the-year blueback herring per 5 min tow with a 10 ft Cobb traw from the James River in 1969. Hollow bar, surface; solid bar, 5 meters. 


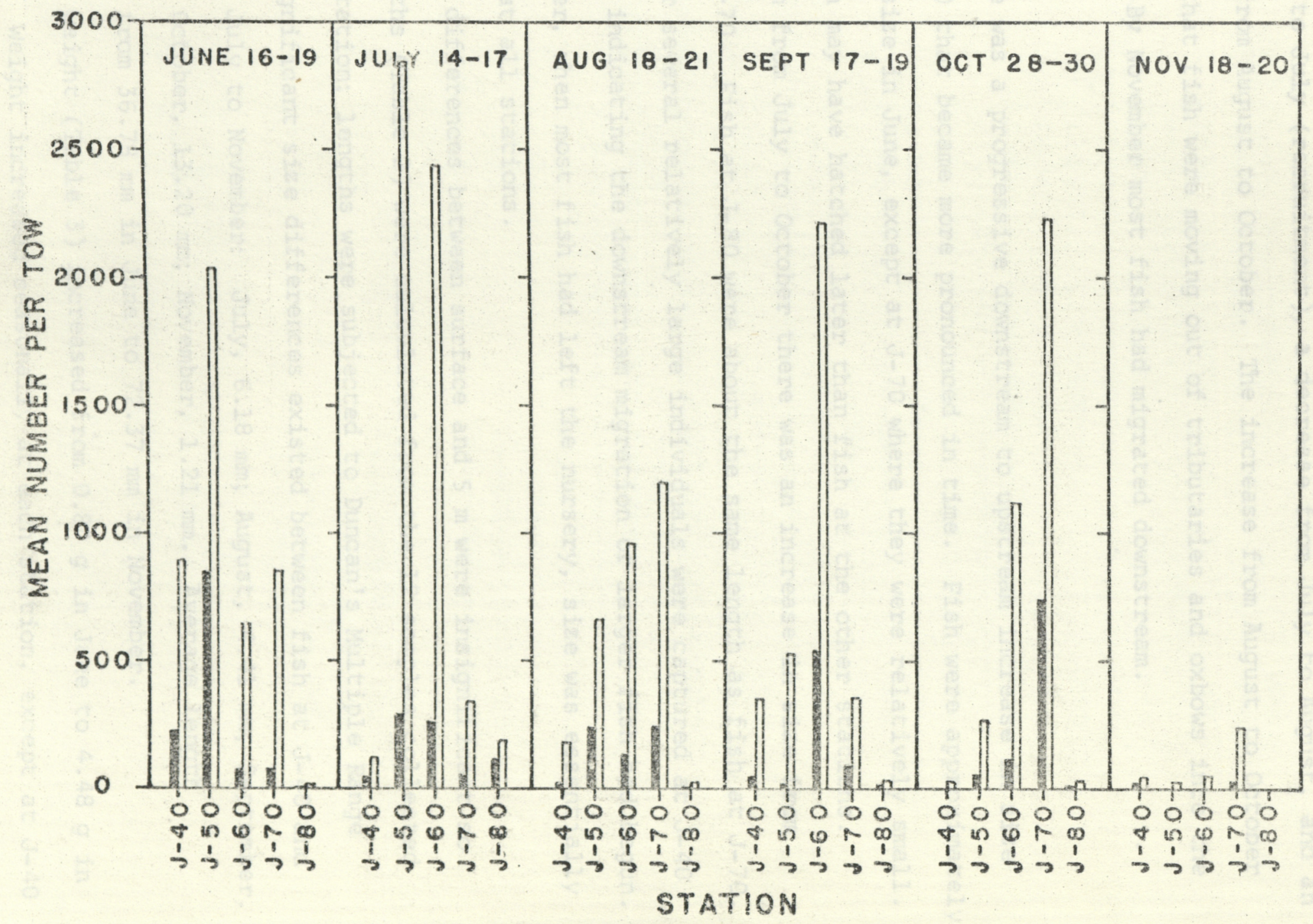


Hurricane Camille). In October and November bluebacks were again most abundant at J-70. Relatively few bluebacks were collected at J-80.

There was an increase in the grand average number per tow (Table I) from June to July (recruitment), a decrease from July to August, and an increase from August to October. The increase from August to October suggests that fish were moving out of tributaries and oxbows into the channel. By November most fish had migrated downstream.

Growth

There was a progressive downstream to upstream increase in size (Figure 5) that became more pronounced in time. Fish were approximately the same size in June, except at J-70 where they were relatively smalI. These fish may have hatched later than fish at the othen stations. Each month from July to October there was an increase in size from J-40 to J-70. Fish at J-80 were about the same length as fish at J-70. In October several relatively large individuals were captured at J-40 and $\mathrm{J}-50$, indicating the downstream mignation of larger fish had begun. In November, when most fish had left the nursery, size was essentially the same at all stations.

Size differences between surface and $5 \mathrm{~m}$ were insignificant so mean lengths (Table 2) were calculated from the 12 samples collected at each station; lengths were subjected to Duncan's Multiple Range Test. Significant size differences existed between fish at J-40 and J-70 from July to November: July, $6.18 \mathrm{~mm}$; August, $4.41 \mathrm{~mm}$; September, $11.24 \mathrm{~mm}$; October, $13.20 \mathrm{~mm}$; November, $1.21 \mathrm{~mm}$. Average length increased from $36.78 \mathrm{~mm}$ in June to $72.37 \mathrm{~mm}$ in November.

Mean weight (Table 3) increased from $0.80 \mathrm{~g}$ in June to $4.48 \mathrm{~g}$ in November. Weight increased seasonally at each station, sxcept at J-40 and J-50 where there was a decrease from August to September. 
Figure 5. Growth of young-of-the-year blueback herring from the James River in 1969. Central vertical line, mean; hollow bar, standard deviation on either side of mean; horizontal line, range. Sample size in parentheses. 


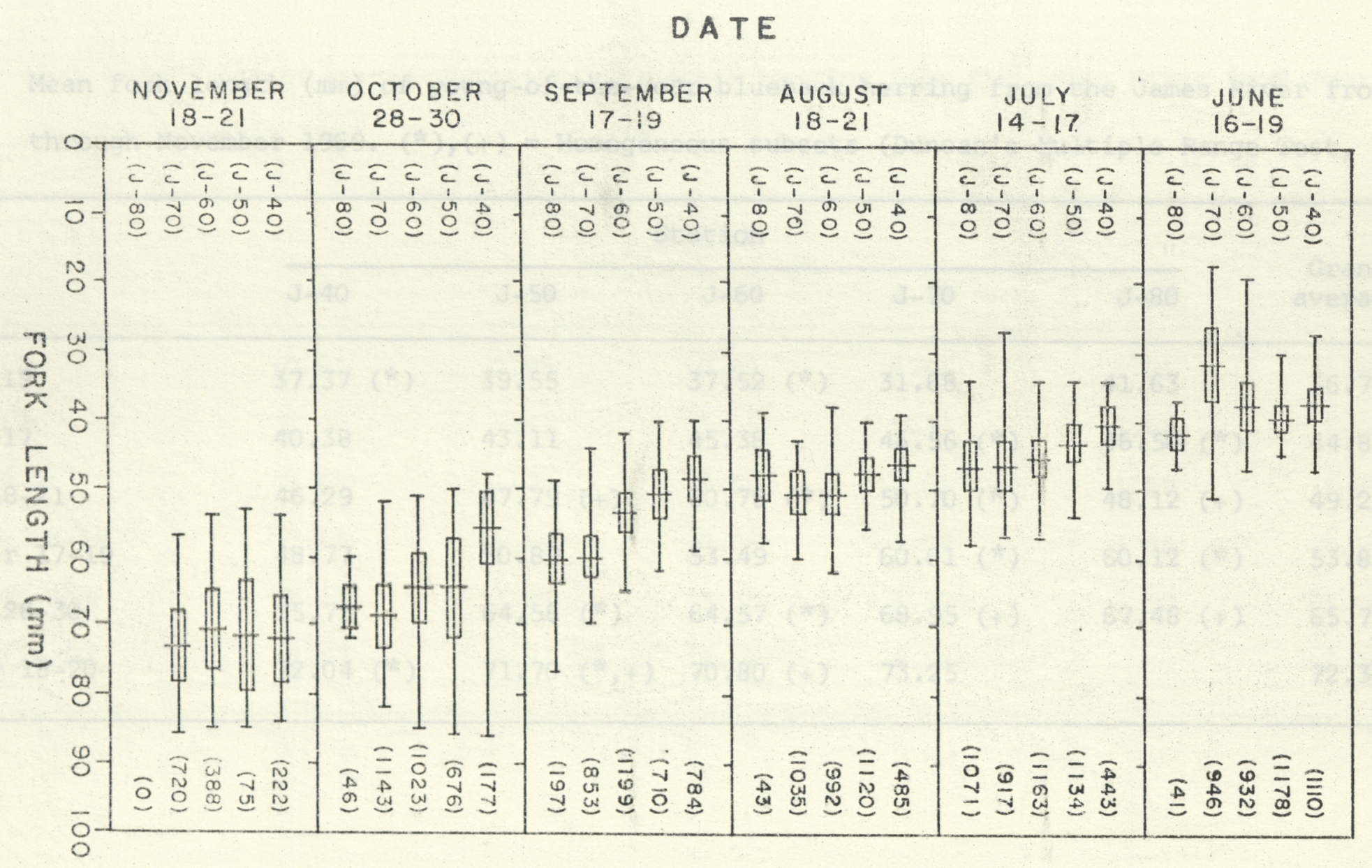


Table 2. Mean fork length ( $\mathrm{mm}$ ) of young-of-the-year blueback herring from the James River from June through November 1969. $(*),(+)=$ Homogeneous subsets (Duncan's Multiple Range Test, P<0.05)

\begin{tabular}{|c|c|c|c|c|c|c|}
\hline \multirow[b]{2}{*}{ Date } & \multicolumn{5}{|c|}{ Station } & \multirow{2}{*}{$\begin{array}{c}\text { Grand } \\
\text { average }\end{array}$} \\
\hline & $J-40$ & $\mathrm{~J}-50$ & $J-60$ & $\mathrm{~J}-70$ & $\mathrm{~J}-80$ & \\
\hline June $16-19$ & $37.37(*)$ & 39.55 & $37.52(*)$ & 31.68 & 41.63 & 36.78 \\
\hline July $\quad 14-17$ & 40.38 & 43.11 & 45.38 & $45.56(*)$ & $46.50(*)$ & 44.85 \\
\hline August $18-21$ & 46.29 & $47.79(+)$ & $50.76(*)$ & $50.70(*)$ & $48.12(+)$ & 49.22 \\
\hline September 17-19 & 48.77 & 50.89 & 53.49 & $60.01 \%$ & $60.12(*)$ & 53.84 \\
\hline October $28-30$ & 55.75 & $64.58(*)$ & $64.57(*)$ & $68.95(t)$ & $67.48(+)$ & 65.74 \\
\hline November $18-20$ & $72.04(*)$ & $71.70(*,+)$ & $70.80(+)$ & 73.25 & & 72.37 \\
\hline
\end{tabular}


Table 3. Mean weight $(g)$ of young-of-the-year blueback herring from the James River from June through November 1959

\begin{tabular}{|c|c|c|c|c|c|c|}
\hline \multirow[b]{2}{*}{ Date } & \multicolumn{5}{|c|}{ Station } & \multirow{2}{*}{$\begin{array}{c}\text { Grand } \\
\text { average }\end{array}$} \\
\hline & $J-40$ & $J-50$ & $J-60$ & $\mathrm{~J}-70$ & $\mathrm{~J}-80$ & \\
\hline June $16-19$ & 0.84 & 0.95 & 0.81 & 0.53 & 1.25 & 0.80 \\
\hline July $14-17$ & 1.07 & 1.37 & 1.55 & 1.70 & 1.68 & 1.51 \\
\hline August $18-21$ & 1.64 & 1.73 & 2.00 & 2.02 & 1.82 & 1.87 \\
\hline September 17-19 & 1.55 & 1.61 & 2.06 & 3.02 & 3.06 & 2.14 \\
\hline October 28-30 & 2.12 & 3.23 & 3.33 & 3.90 & 3.90 & 3.46 \\
\hline November $18-20$ & 4.47 & 4.73 & 4.38 & 4.52 & & 4.48 \\
\hline
\end{tabular}


The Condition Factor $(K)$ (Table 4 and Eigure 6 ) was determined from mean length and weight data using the formula (Becknan, 1948):

$$
K=\frac{W \times 10^{5}}{L^{3}}
$$

where $W=$ mean weight,

and $I_{s}=$ mean length.

There was no particular pattern of condition of fish between stations, but there was a marked decrease in condition after flooding from Hunricane camille. The avenage $K$ value was 1.60 in June, 1.68 in July, and 1.57 in August. In September, however, it had dropped to 1.37, and decreased from 1.22 in october to 1.18 in November.

Zooplankton Standing Crops

Zooplankton standing crops as number per liter and percent composition are presented in Appendix A (Tables AI to AlO). Dominant: organisms with respect to numbers in plankton samples and/or stomachs are presented in Ejgures 7 and 8 . These items constituted on the average not less than $96 \%$ of the plankton and not less than $92 \%$ of the stomach contents. Only sampling periods when fish were captured are included.

Copepod nauplii were generally more abundant at surface than $5 \mathrm{~m}$. Numbers were highest at J-60 every month except August, when nauplii. were most abundant at J-50. Copepodites, on the other hand, were more abundant at: $5 \mathrm{~m}$ than at sumface. Numbers were highest at $\mathrm{J}-60$ every month. Eurytemora affinis (Calanoida) and Cyclops vernalis (Cyclopoida) were found at every station and were always more abundant at $5 \mathrm{~m}$ than at surface. Their density was usually highest at the midstream stations (J-50 to J-70), except in June when E. affinis was most abundant at $j-40$. Canthocamptus robertcokerj (Herpacticoida) was 
Table 4. Condition factor $(K)$ of young-of-the-year blueback herring from the James River from June through November 1969

\begin{tabular}{|c|c|c|c|c|c|c|}
\hline \multirow[b]{2}{*}{ Date } & \multicolumn{5}{|c|}{ Station } & \multirow{2}{*}{$\begin{array}{c}\text { Grand } \\
\text { average }\end{array}$} \\
\hline & $J-40$ & $J-50$ & $J-60$ & $\mathrm{~J}-70$ & $\mathrm{~J}-80$ & \\
\hline June $16-19$ & 1.61 & 1.53 & 1.53 & 1.56 & 1.73 & 1.60 \\
\hline July $14-17$ & 1.62 & 1.71 & 1.65 & 1.67 & 1.67 & 1.68 \\
\hline August $18-21$ & 1.66 & 1.58 & 1.53 & 1.55 & 1.63 & 1.57 \\
\hline September 17-19 & 1.33 & 1.22 & 1.35 & 1.40 & 1.41 & 1.37 \\
\hline October $28-30$ & 1.23 & 1.20 & 1.24 & 1.19 & 1.27 & 1.22 \\
\hline November $18-20$ & 1.20 & 1.28 & 1.23 & 1.15 & & 1.18 \\
\hline
\end{tabular}


Figure 6. Condition factor $(K)$ of young-of-the-year blueback herring from the James River in 1969. 


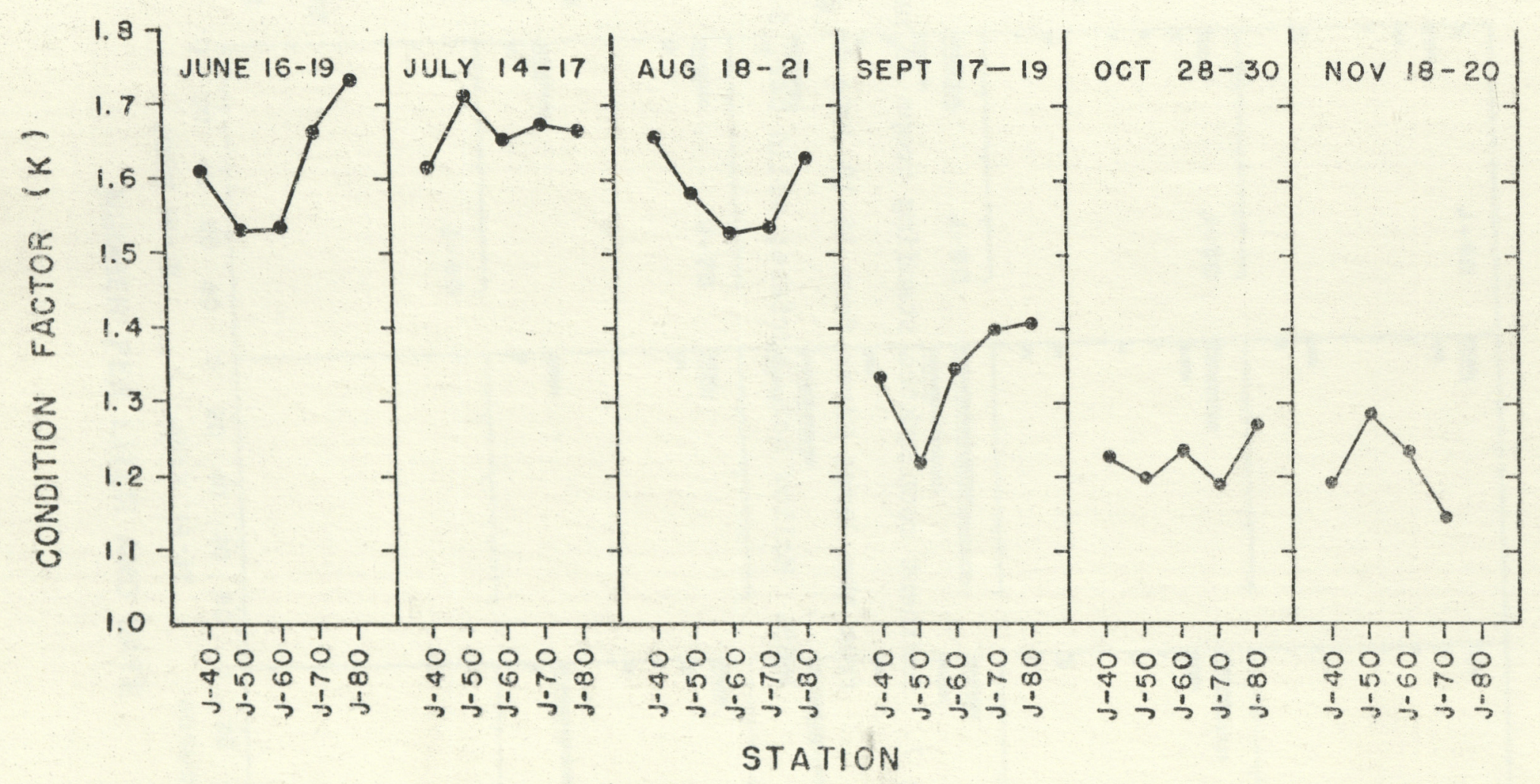


Eigure 7. Dominant zooplankton standing crops as number per liter from the James River from 16-19 June to 18-21 August 1969. Hollow bar, surface; solid bar, 5 meters. 
NAUPLII

COPEPODITES

EURYTEMORA

GYGLOPS

CANTHOCAMPTUS

BOSMINA

DIAPHAMOSOMA

MAUPLII

COPEPODITES

EURYTEMORA

GYCLOPS

CANTHOCAMPTUS

BOSMINA

DIAPHANOSOMA

NAUPLII

COPEPODITES

EURYTEMORA

CYCLOPS

GANTHOCAMPTUS

BOSMINA

DIAPHANOSOMA

NAUPLII

COPEPODITES

EURYTEMORA

CYCLOPS

CANTHOCAMPTUS

BOSMINA

DIAPHANOSOMA

NAUPLII

COPEPODITES

EURYTEMORA

CYCLOPS

CANTHOCAMPTUS

BOSMINA

DIAPHANOSOMA

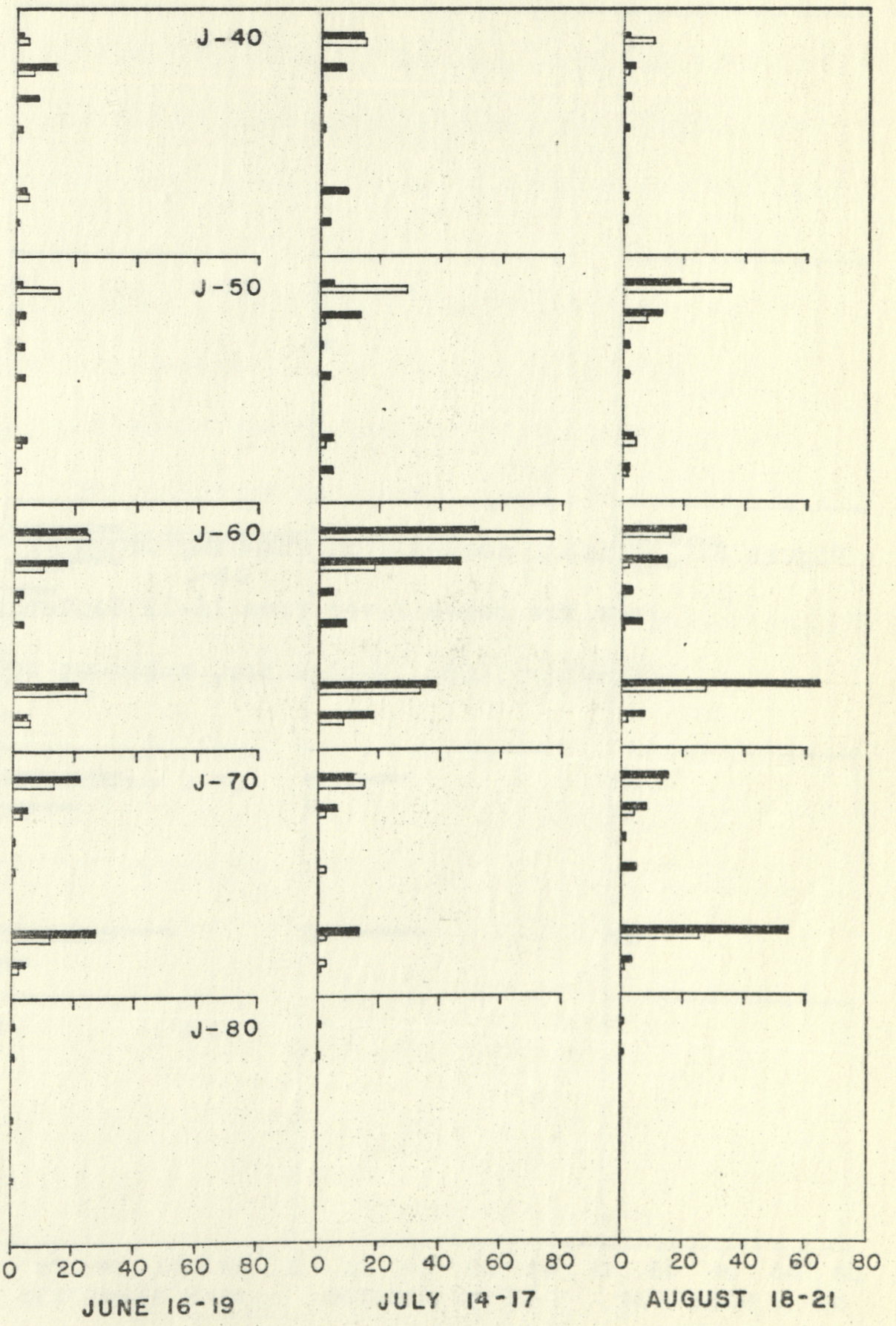

NUMBER PER LITER AND DATE 
Figure 8. Dominant zooplankton standing crops as number per liter from the James River from 16-19 September to 18-20 November 1969. Hollow bar, surface; solid bar, 5 meters. 
NA HPLII

COPEPODITES

EURYTEMORA

GVGLOPS

GAMTHOCAMPTUS

DOSMINA

DIAPHANOSOMA

NAUPLII

COPEPODITES

EURYTEMORA

CYCLOPS

CANTHOCAMPTUS

BOSMINA

DIAPHANOSOMA

NAUPLII

COPEPODITES

EURYTEMORA

CYCLOPS

CANTHOCAMPTUS

BOSMINA

DIAPHANOSOMA

NAUPLII

COPEPODITES

EURYTEMORA

CYCLOPS

CANTHOCAMPTUS

BOSMINA

DIAPHANOSOMA

NAUPLII

COPEPODITES

EURYTEMORA

CYCLOPS

CANTHOCAMPTUS

BOSMINA

DIAPMANOSOMA

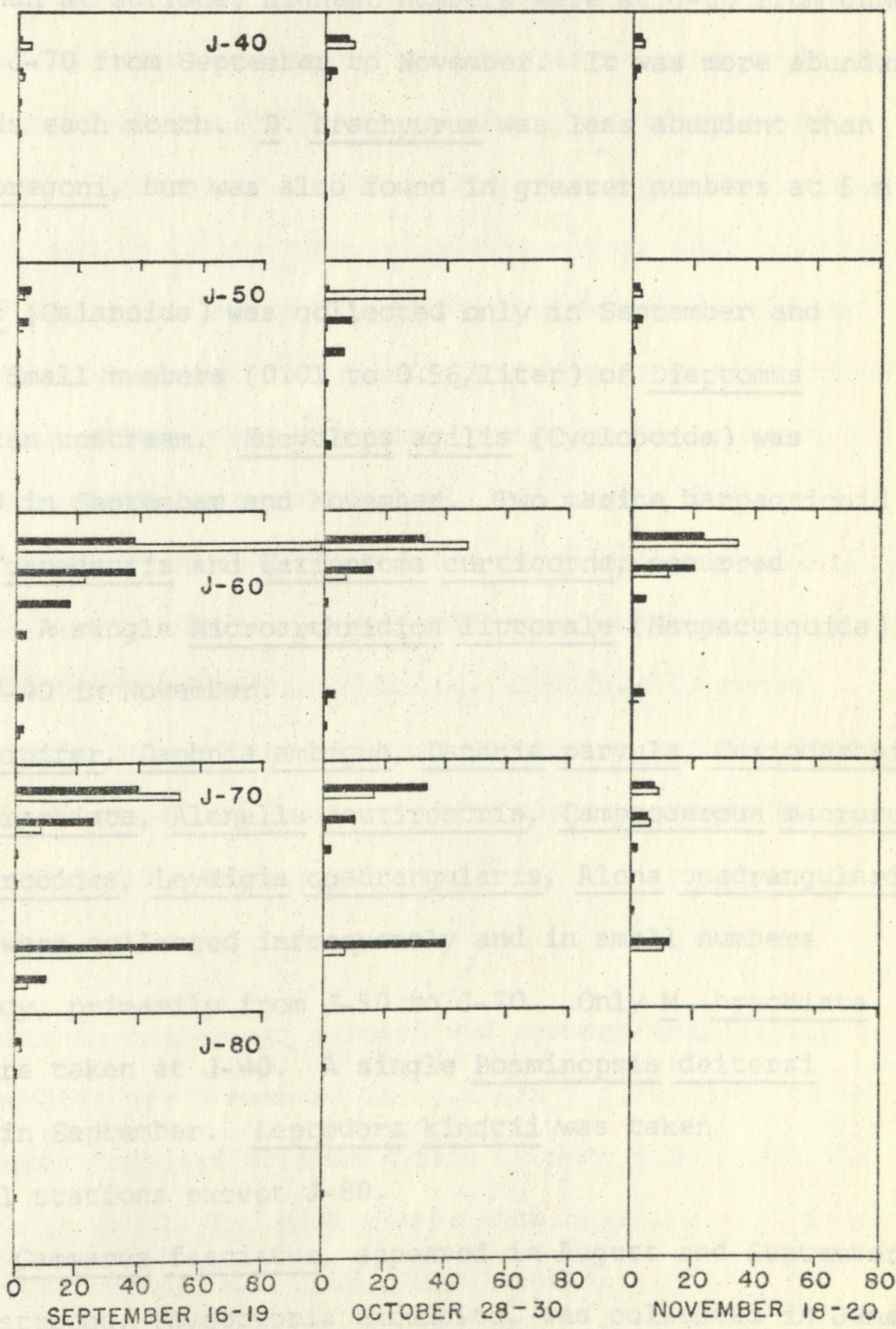

NUMBER PER LITER AND DATE 
collected only in November and in small numbers ( 0.03 to $0.05 / 1$ iter). Bosmina Ionginostris-coregoni and Diaphanosoma brachyurum were the dominant cladocerans. B. longirostris-coregoni was generally more abundant at $5 \mathrm{~m}$ than at surface; highest numbers were at $\mathrm{J}$-60 from June to August, and at j-70 from September to Novenber. It was more abundant than adult copepods each month. ‥ brachyurum was less abundant than B. Iongirostris-coregoni, but was also found in greater numbers at $5 \mathrm{~m}$ than at surface.

Acartia tonsa (Calanoida) was collected only in September and October at J-40. Small numbers (0.01 to $0.56 / 1$ iter) of Diaptornus reighardi were taken upstream. Eucyclops agilis (Cyclopoida) was found only at J-80 in September and November. Two marine harpacticoid species, CanuejIa canadensis and Ectinosoma curticonne, occurned primarily at $\mathrm{J}-40$. A single Microanchnidion litconale (Hanpacticoida) was collected at J-40 in Novemiber.

Ilyooyptus spirifen, Daphnia ambigua, Daphnia parvula, Ceriodaphnia Iacustris, Moina brachiata, Alonella acutinostris, Camptocercus macrurus, Leydigia acanthocencoides, Leydigia quadrangularis, Alona guadrangulanis, and Alona guttata were collected infrequentiy and in small numbers throughout the study, primarily from J-50 to J-70. Only $\mathrm{M}$. brachiata and I. spinifer were taken at $J-40$. A single Bosminopsis deitersi was found at J-80 in September. Leptodona kindtii was taken occasionally at alI stations except J-80.

The amphipod, Gammanus fasciatus, appeared in August and September samples, and the ostracod, Physocypria exquisita, was collected in June, July, and August in smal1 numbens. A single mysid, Neorysis amenicana, was found at $J-40$ in November.

Dipteran Iarvae, Procladius adumbratus and Chaoborus sp., occurred 
in samples from June to August, primarily at $\mathrm{J}-70$ and $\mathrm{J}-80$. An oligochaete, Pristina breviseta, was taken from J-50 to J-80, but most often at $\mathrm{J}-80$.

Total number of zooplankton per liter by depth and station (Figure 9) shows that standing crops were higher at $5 \mathrm{~m}$ than at surface at only slightly more than half of the stations, and that, excluding $\mathrm{J}-80$, there was an upstream increase in density. From June through August, and on 30 september and 18-20 November, zooplankton were most abundant at J-60. On 17-19 September and 28-30 October abundance was highest at $\mathrm{J}-70$. Over the entire period zooplankton standing crops were higher at $\mathrm{J}-60$ and J-70 than at the other stations, except on $21 \mathrm{JuIy}$ and 29 August. Few organisms were captured at J-80 (1ess than $3.25 /$ Iiter). Standing crops increased from 16-19 June to 30 June, and were relatively high through 18-21. August. There was a significant reduction in density on 29 August, shortly after Hurricane Camille. By 17-19 September zooplankton populations at J-60 and J-70 had apparently recovered and standing crops were at pre-flood levels. There was a decrease in numbers from september to November.

Selective Feeding

Stomach contents as number per stomach and percent composition for the six sampling periods are presented in Appendix B (Tables BI to B6). To compare the percent composition from a fish stomach sample and its corresponding plankton sample for each zooplankton organism an $E$ index given by the following formula was used (Ivlev, 1961):

$$
E=\frac{r_{i}-P_{i}}{r_{i}+P_{i}}
$$

where $E=$ electivity (selectivity), $r_{i}=\%$ composition of plankter $i$ in the stomach, and $P_{i}=\%$ composition of plankter $i$ in the plankton. 
Figure 9. Total zooplankton standing crops as number per. liter from the James River in 1969. Hollow bar, surface; solid bar, 5 meters. 


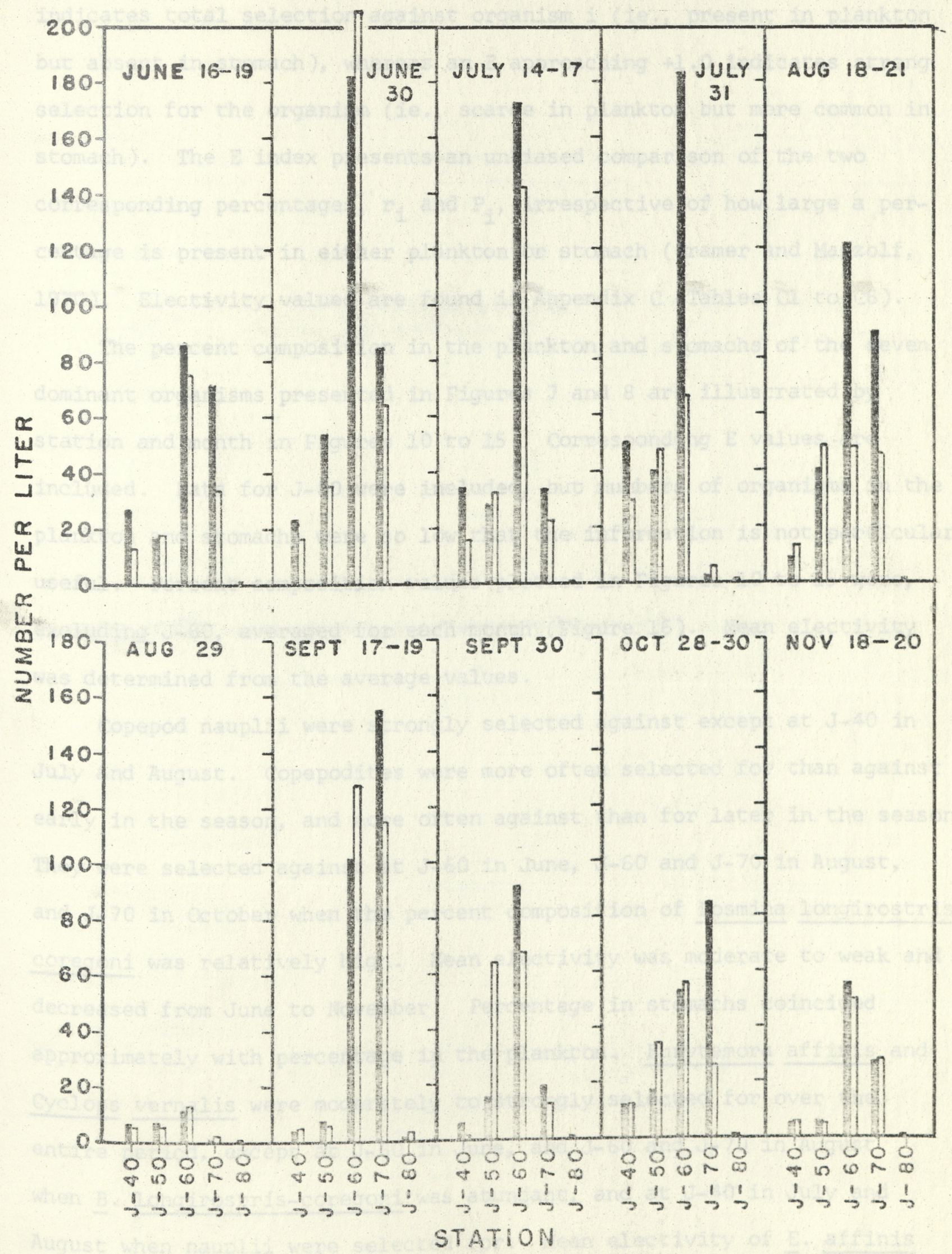


This index yields $E$ values between -1.0 and +1.0 . An $E$ of -1.0 indicates total selection against organism i (ie., present in plankton but absent in stomach), whereas an $E$ approaching +1.0 indicates strong selection for the organism (ie., scarce in plankton but more common in stomach). The $\mathrm{E}$ index presents an unbiased comparison of the two corresponding percentages, $r_{i}$ and $P_{i}$, irrespective of how large a percentage is present in either plankton or stomach (Cramer and Marzolf, 1970). Electivity values are found in Appendix C (Tables Cl to C6). The percent composition in the plankton and stomachs of the seven dominant organisms presented in Figures 7 and 8 are illustrated by station and month in Figures 10 to 15 . Corresponding E values are included. Data for J-80 were included, but numbers of organisms in the plankton and stomachs were so low that the information is not particularly useful. Percent composition values plotted in Figures 10 to 15 were, excluding J-80, averaged for each month (Figure 16). Mean electivity was determined from the average values.

Copepod nauplii were strongly selected against except at J-40 in July and August. Copepodites were more often selected for than against early in the season, and more often against than for later in the season. They were selected against at J-60 in June, J-60 and J-70 in August, and J.-70 in October when the percent composition of Bosmina Iongirostriscoregoni was relatively high. Mean electivity was moderate to weak and decreased from June to November. Percentage in stomachs coincided approximately with percentage in the plankton. Eurytemora affinis and Cyclops vernalis were moderately to strongly selected for over the entire period, except at J-60 in June, and J-60 and J-70 in August when $\underline{B}$. Iongirostris-coregoni was abundant, and at J-40 in July and August when nauplii were selected for. Mean electivity of E. affinis 
Figure 10. Percentage in the plankton and stomachs, and electivity index (E) of the dominant zooplankton from the James River on 16-19 June 1969. Hollow bar, surface; solid bar, 5 meters. 


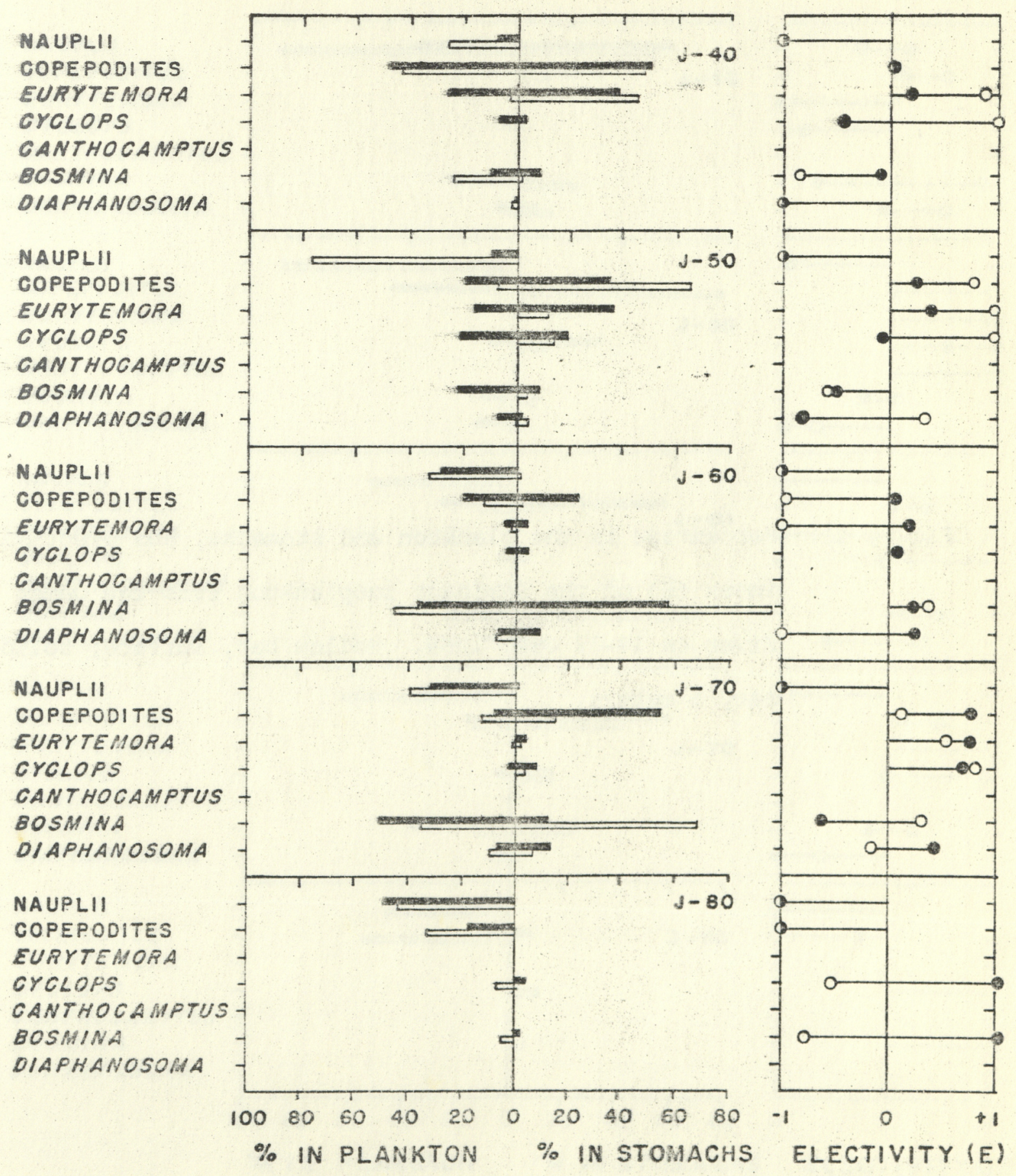


Figure 11. Percentage in the plankton and stomachs, and electivity index (E) of the dominant zooplankton from the James River on 14-17 July 1969. Hollow bar, surface; solid bar, 5 meters. 
NAUPLII
COPEPODITES
EURYTEMORA
CYCLOPS
GANTHOGAMPTUS
BOSHINA
DIAPHANOSOMA
NAUPLII
COPEPODITES
EURYTEMORA
CYCLOPS
GANTHOCAMPTUS
BOSMINA
DIAPHANOSOMA

NAUPLII

COPEPODITES

EURYTEMORA

CYCLOPS

CANTHOGAMPTUS

BOSMINA

DIAPHANOSOMA

NAUPLII

COPEPODITES

EURYTEMORA

CYCLOPS

CANTHOCAMPTUS

BOSMINA

DIAPHANOSOMA

NAUPLII

COPEPODITES

EURYTEMORA

CYCLOPS

CANTHOCAMPTUS

BOSMINA

DIAPHANOSORA
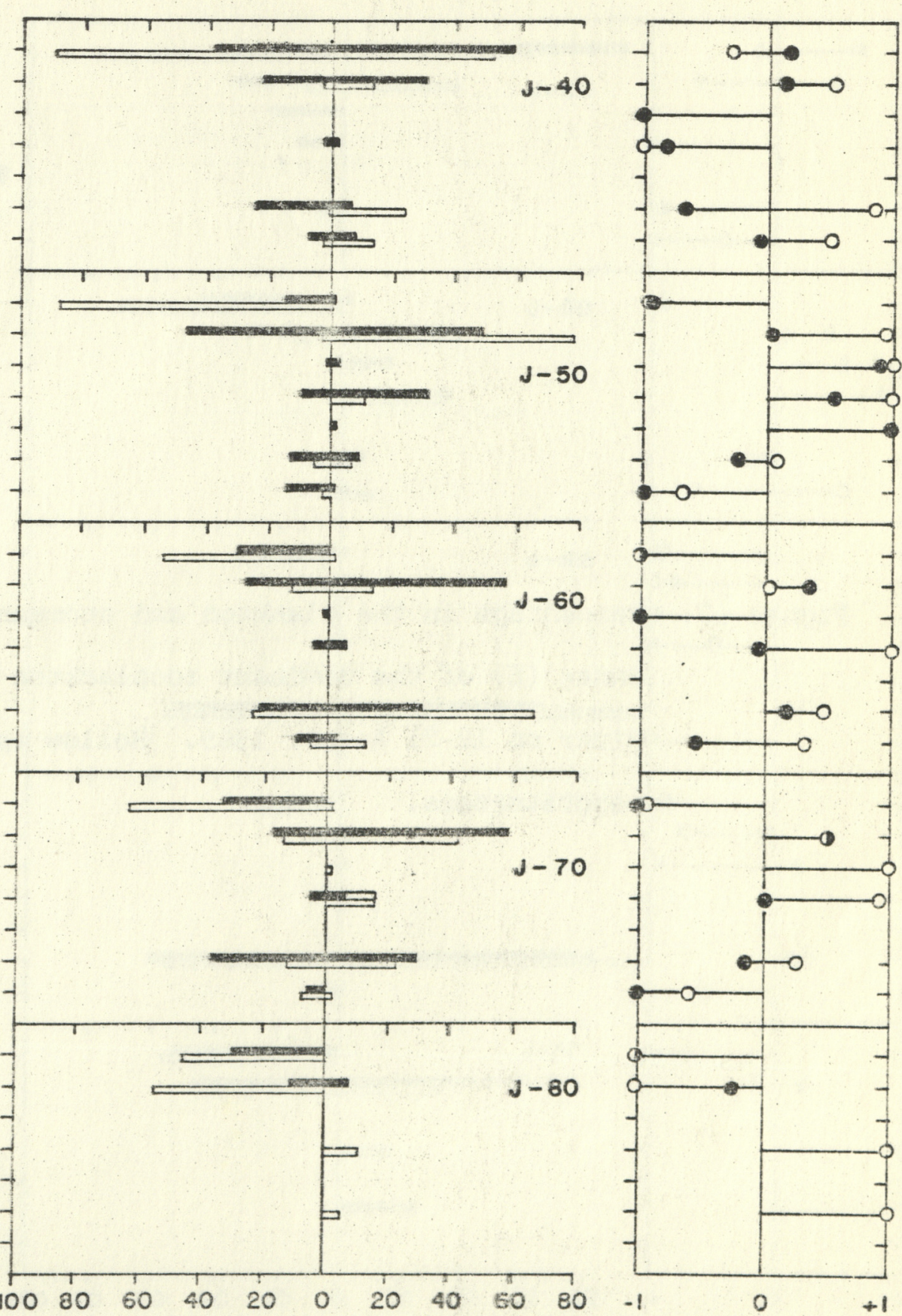

$\%$ IN PLANKTON \% IN STOMACHS
ELECTIVITY (E) 
Figure 12. Percentage in the plankton and stomachs, and electivity index (E) of the dominant zooplankton from the James River on 18-21 August 1969. Hollow bar, surface, solid bar, 5 meters. 
NAUPLII COPEPODITES EURYTEMORA CYCLOPS

CANTHOCAMPTUS BOSMINA DIAPHANOSOMA

NAUPLII COPEPODITES EURYTEMORA CYCLOPS GANTHOGAMPTUS BOSMINA DIAPHANOSOMA

NAUPLII COPEPODITES EURYTEMORA CYCLOPS CANTHOCAMPTUS BOSMINA DIAPHANOSOMA

NAUPLII COPEPODITES EURYTEMORA CYCLOPS

CANTHOCAMPTUS BOSMINA DIAPHANOSORA

NAUPLII COPEPODITES EURYTEMORA CYCLOPS

CANTHOCAMPTUS BOSMINA DIAPHANOSOMA

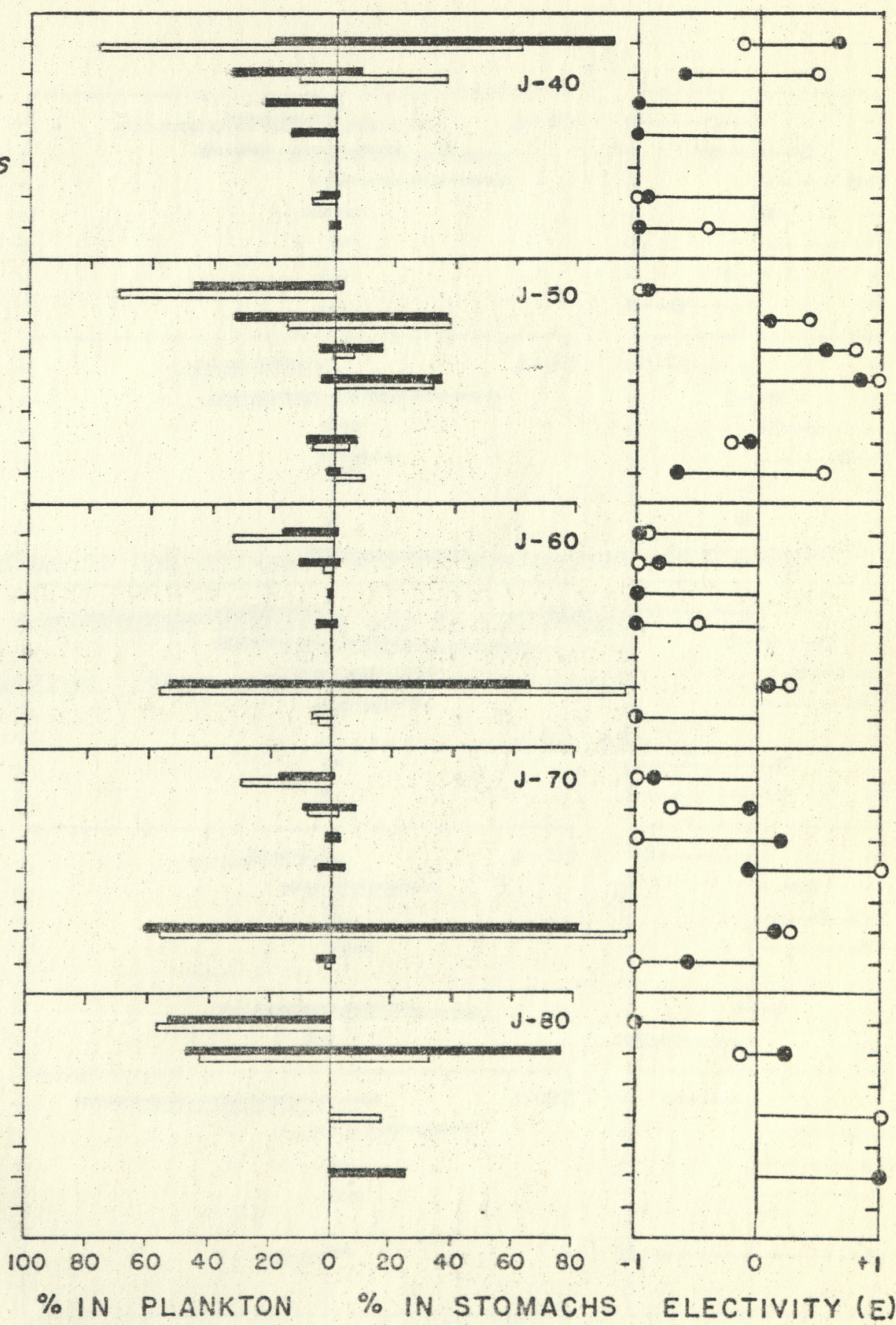


Figure 13. Percentage in the plankton and stomachs, and electivity index ( $E_{1}$ ) of the dominant zooplankton from the James River on 17-19 September 1969. Hollow bar, surface; solid bar, 5 meters. 
NAUPLII

COPEPODITES

EURYTEMORA GYCLOPS

GANTHOCAMPTUS BOSMINA

DIAPHANOSOMA

NAUPLII

COPEPODITES

EURYTEMORA

CYCLOPS

CANTHOCAMPTUS

BOSMINA

DIAPHANOSOMA

NAUPLII

COPEPODITES

EURYTEHORA

CYCLOPS

CANTHOCAMPTUS

BOSMINA

DIAPHANOSOMA

NAUPLII

COPEPODITES

EURYTEMORA

CYCLOPS

CANTHOCAMPTUS

BOSMINA

DIAPHANOSOMA

NAUPLII

COPEPODITES

EURYTEMORA

CYCLOPS

CANTHOCAMPTUS

BOSMINA.

DIAPHANOSOMA
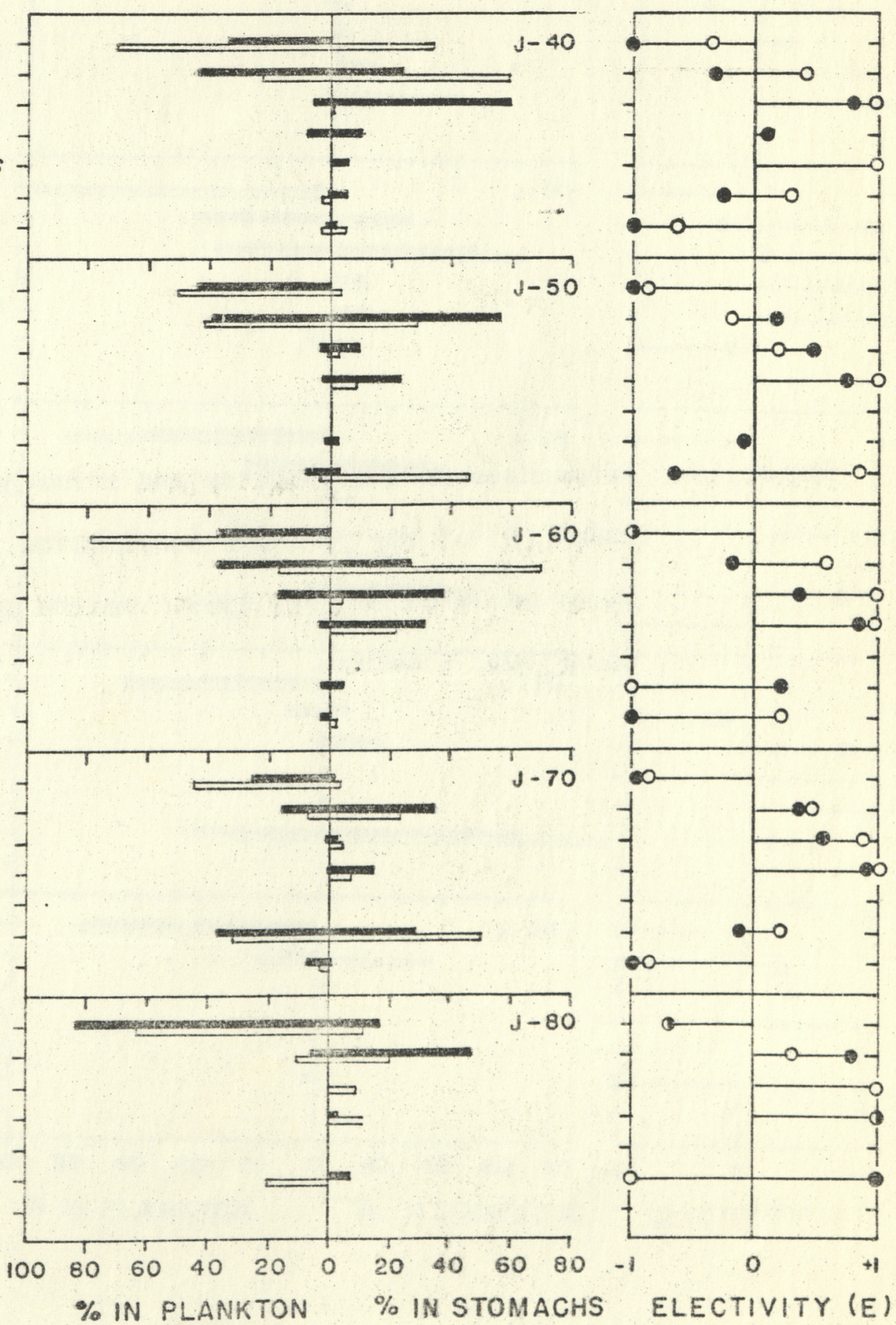
Figure 14. Percentage in the plankton and stomachs, and electivity index (E) of the dominant zooplankton from the James River on 28-30 October 1.969. Hollow bar, surface; solid bar, 5 meters. 
NAUPLII

COPEPODITES

EURYTEMORA

CYCLOPS

CANTHOCAMPTUS

BOSMINA

DIAPHANOSOMA

NAUPLII.

COPEPODITES

EURYTEMORA

CYCLOPS

GANTHOCAMPTUS

BOSMINA

DIAPHANOSOMA

NAUPLII

COPEPODITES

EURYTEMORA

CYCLOPS

CANTHOCAMPTUS

BOSMINA

DIAPHANOSOMA

NAUPLII

COPEPODITES

EURYTEMORA

CYCLOPS

CANTHOCAMPTUS

BOSMINA

DIAPHANOSOMA

NAUPLII

COPEPODITES EURYTEMORA

CYCLOPS

CANTHOCAMPTUS BOSMINA

DIAPHANOSOMA

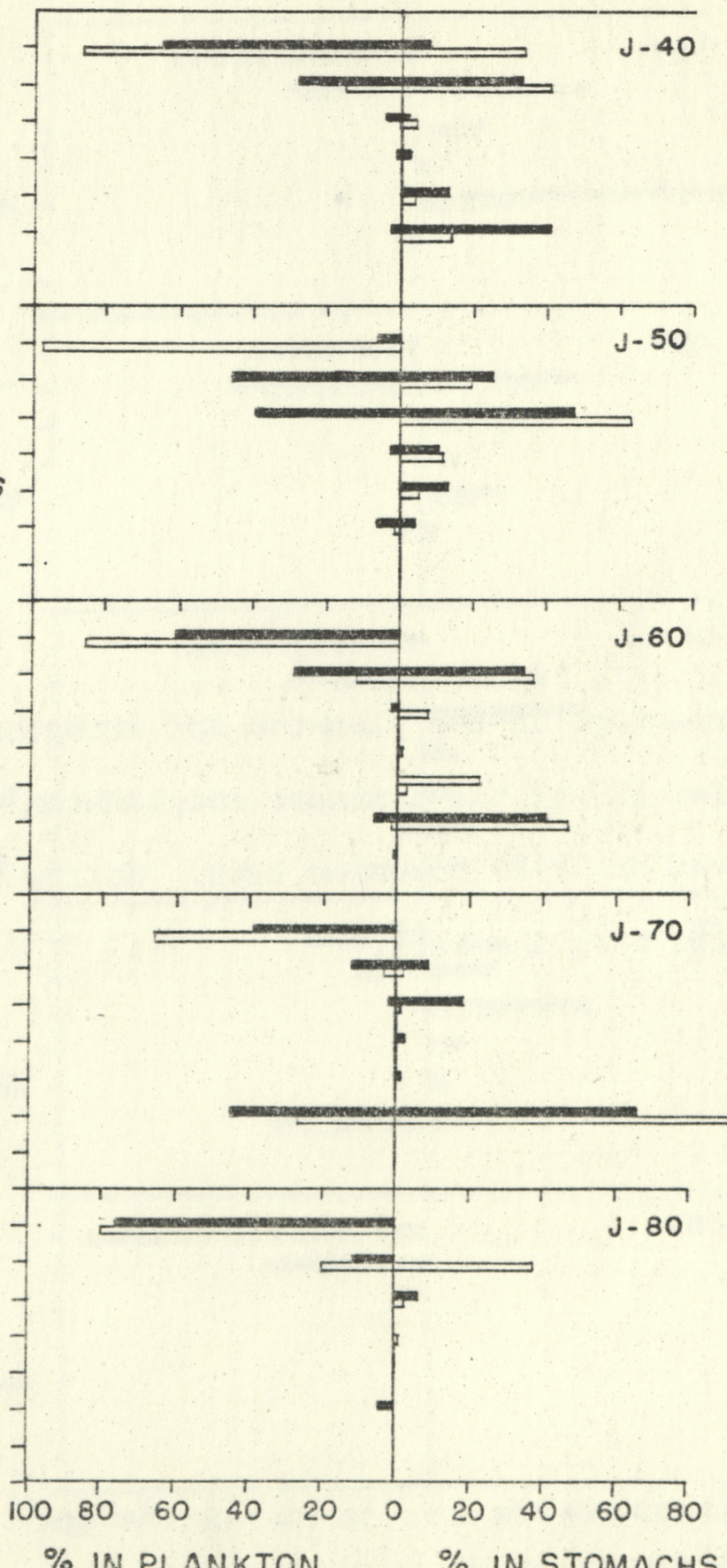

$\%$ IN PLANKTON

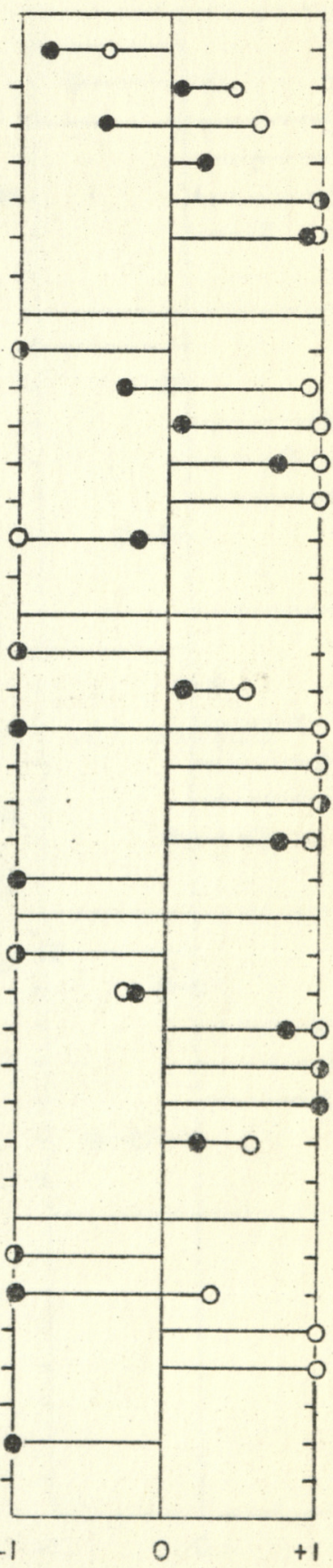

ELECTIVITY (E) 
Figure 15. Percentage in the plankton and stomachs, and electivity index (E) of the dominart zooplankton fron the James River on 18-20 November 1969. Hollow bar, surface; solid bar, 5 meters. 
NAUPLII

COPEPODITES

EURYTEMORA

CYCLOPS

CANTHOCAMPTUS

BOSMINA

DIAPHANOSOMA

NAUPLII

COPEPODITES

EURYTEMORA

CYCLOPS

CANTHOCAMPTUS

BOSMINA

DIAPMANOSOMA

NAUPLII

COPEPODITES

EURYTEMORA

CYCLOPS

CANTHOCAMPTUS

BOSMINA

DIAPHANOSOMA

NAUPLII

COPEPODITES

EURYTEMORA

CYCLOPS

CANTHOCAMPTUS

BOSMINA

DIAPHANOSOMA

NAUPLII

COPEPODITES

EURYTEMORA

CYCLOPS

CANTHOCAMPTUS BOSMINA

DIAPHANOSOMA

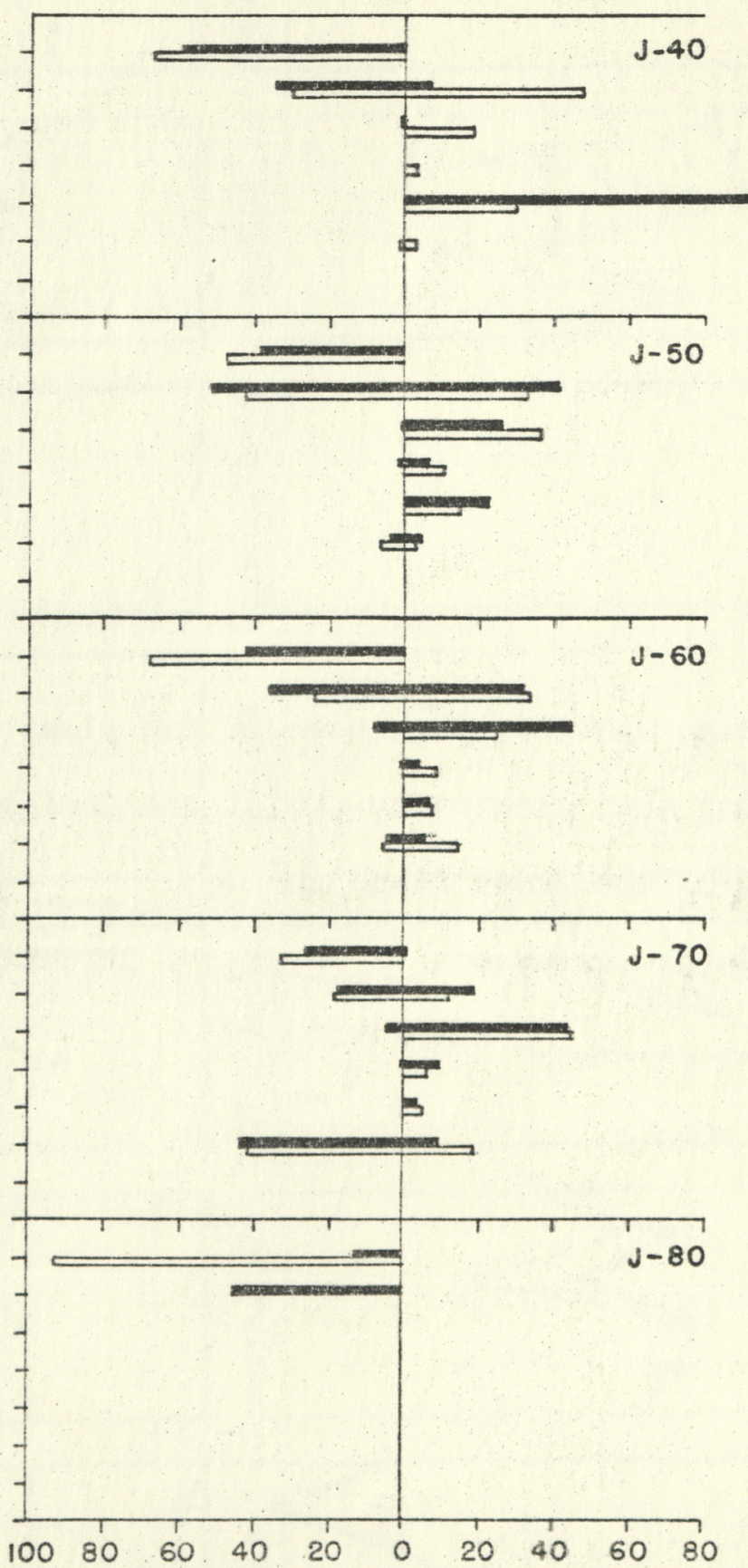

$\%$ IN PLANKTON

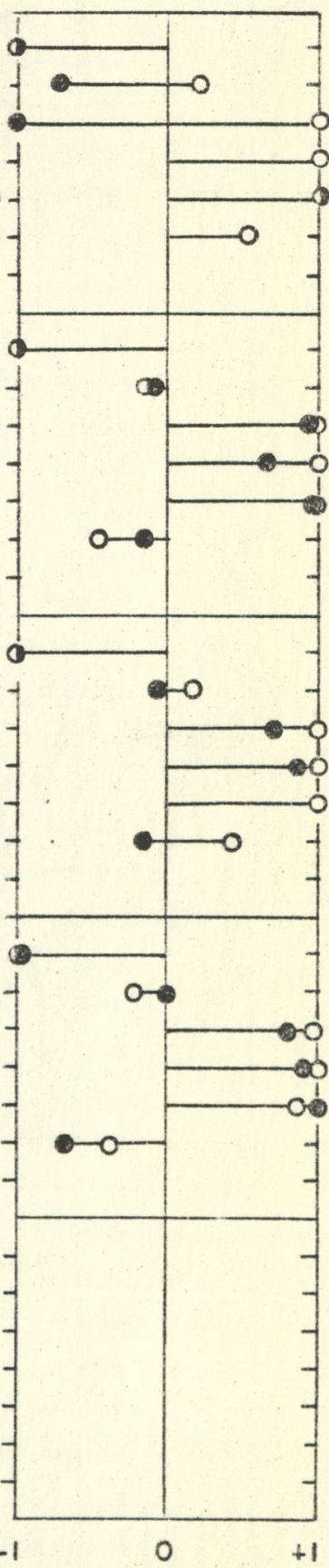

ELECTIVITY (E) 
Figure 16. Mean monthly percentage in the plankton and stomachs, and mean electivity (E) of the dominant zooplankton from the James River in 1969. ___ percentage in the plankton; .........., percentage in the stomachs; -..........., electivity (E). 

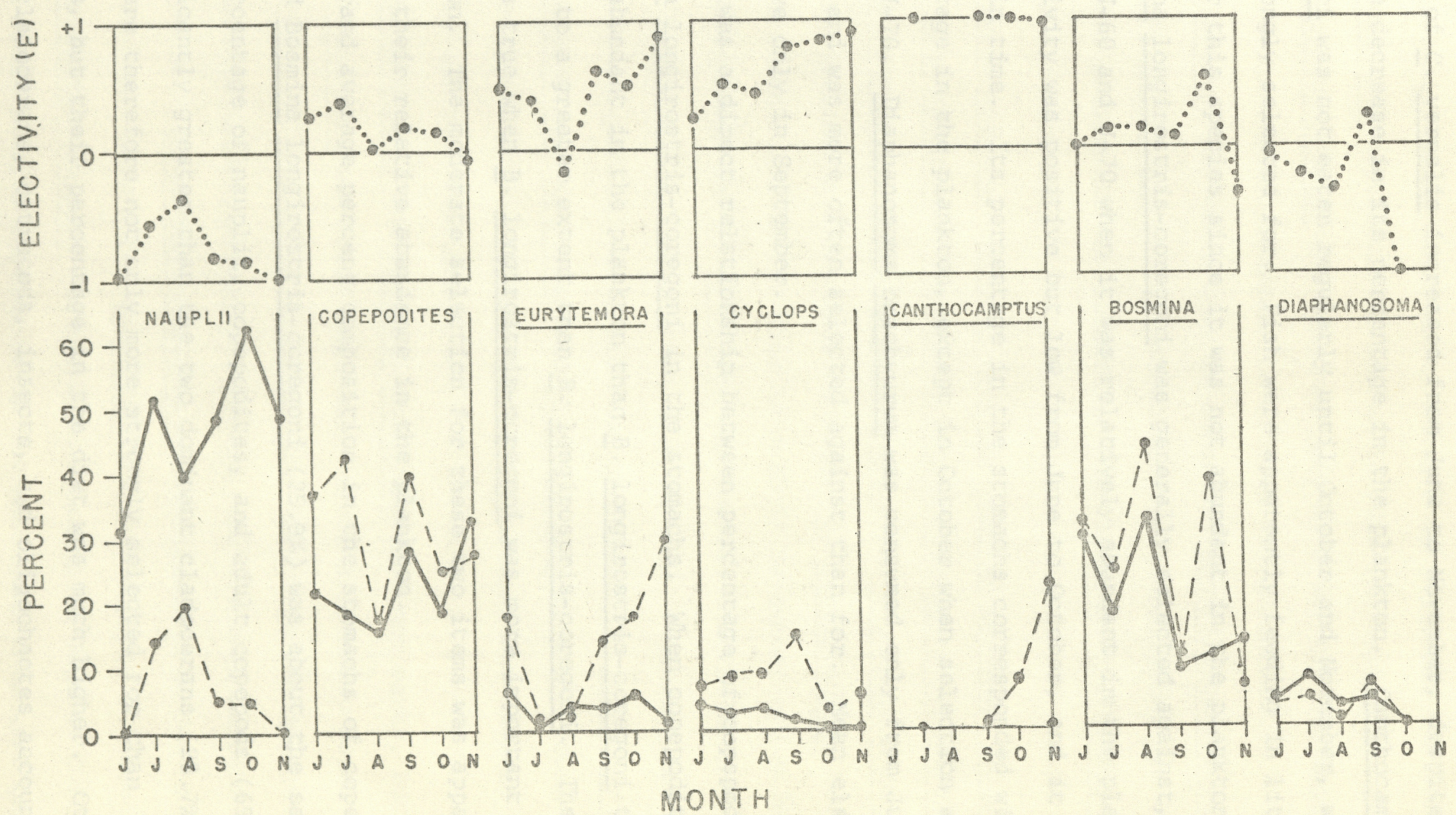

MONTH

$w$ 
was negative in August but increased from August to November. Mean electivity of $\underline{C}$. vernalis increased from June to November, despite a progressive decrease in its percentage in the plankton. Canthocamptus robentcokeri was not eaten regularly until. October and November, when it was strongly selected for. Fish were apparently feeding in littoral. regions for this species since it was not abundant in the plankton. Bosmina longirostris-coregoni. was generally selected against, except at $\mathrm{J}-60$ and $\mathrm{J}-70$ when it was relatively abundant in the plankton. Mean electivity was positive but low from June to October, and it decreased in time. Its percentage in the stomachs corresponded with its pencentage in the plankton, except in October when selection was strong at J-70. Diaphanosoma brachyurum was consumed oniy from June to September, and was more often selected against than for. Mean electivity was positive only in september.

There was a direct relationship between percentage of copepodites and Bosmina Iongirostris-conegoni in the stomachs. When copepodites were more abundant in the plankton than $B$. longirostris-coregoni they were eaten to a greater extent than $\underline{B}$. Iongirostris-coregoni. The reverse was true when $B$. Iongirostris-coregoni was more important in the plankton. The moderate selection for these two items was apparentIy related to their relative abundance in the plankton.

The grand average percent composition in the stomachs of copepodites (31.2\%) and Bosmina Iongirostris-coregoni (25.9\%) was about the same, but the percentage of nauplii, copepodites, and adult copepods ( $65.7 \%$ ) was significantly greater than the two dominant cladocerans (28.7\%). Copepods were therefore not only more strongly selected for than cladocerans, but thein percentage in the diet was much higher. Other copepods, cladocerans, ostracods, insects, and oligochaetes accounted 
for only $5.6 \%$ of the diet.

Acartia tonsa was eaten in small numbers in september. A few Diaptomus reighardi appeared in stomachs in June and september, primarily at J-80. Eucyclops agilis was consumed only at $\mathrm{J}-80$, and its importance increased from June ( $0.32 /$ stomach) to cctober ( $47.78 /$ stomach). Halicyclops fosteni was eaten only in June, and Canuella canadensis and Ectinosona curticonne were selected for occasionally but not eveny time they were present in the plankton. Microarthridion Iittorale was not found in the stomachs.

Ilyocryptus spinifer, Daphnia ambigua, Daphnia parvula, Ceriodaphnia lacustris, Moina brachiata, Alonella acutinostris, Leydigia acanthocencoides, Leydigia guadrangularis, Alona quadrangularis, and Leptodora kindtij. were eaten irregularly and in small numbers. A. acutirostris, however, was relatively important in the diet at J-60 in september and $\mathrm{J}-70$ in Octoben and November, and $\mathrm{M}$. Brachiata was important at. $\mathrm{J}-70$ in September. Electivity was most often -1.0 or +1.0 , depending upon where the item was present (ie., pjankton or stomach). Bosminopsis deitensi, Camptocercus macrurus, and Alona guttata were not found in stomachs during the study. Percentage of cladocenans was highest in stomachs from upstream stations.

Gammanus fasciatus and Neomysis americana were not eaten, but Physocypria exquisita was found regularly in the diet every month at all station except $\mathrm{J}-40$, which suggests that fish were feeding in littoral regions. It was strongly selected for, although numbers in stomachs were Low. Procladius adumbratus was important at J-80 from June to september. Onjy a few chaoborus sp. were eaten. A Iarge number of Pristina breviseta was found in stomachs in June at J-80. Although no adult insects were found in the plankton, they were prey 
at J-80 in June, JuIy, and August.

Feeding periodicity determined from Potonac River samples (Figure 17) indicates that active feeding began at dawn and continued until dusk, and that stomachs emptied during the night. There was one peak in stomach weight per gram of fish in both July and October. The peak, where stomachs reached maximum fullness, occurred at dusk (about 1800). There was a decrease in stomach weight from dusk to dawn (about 0700), when the period of increase in stomach weight began. BIuebacks in the James probably exhibit the same feeding behavion as in the Potomac since the rivers are equally turbid.

A plot of stomach weight per gram of fish (Figure 18) indicates that in most cases stomachs from fish taken at surface were proportionally heavier (ie., more full.) than stomachs from fish taken at $5 \mathrm{~m}$. In addition, stomachs from fish taken at the mid stations ( $\mathrm{J}-50$ to J-70) were, from July to November, generally heavier than stomachs from fish taken at J-40 and J-80. Differences between stations were obviousIy partly dependent upon time of day at which samples were taken. Individual stations, however, were sampled at approximately the same time each month: J-40, 1100 to 1317 ; J-50, 1030 to 1300; J-60, 0725 to 0910; J.70, 0813 to 0913; J-80, 1205 to 1400. Values from J-40, J-50, and J-80 were therefore comparable, since samples from these stations were taken at about midday. Values from J-60 and J-70 would probably have been higher if these stations had been sampled at the same time as the other stations. Samples at J-60 and J-70 were taken earlier in the active feeding period (Figure 1.7) than samples from the other three station. With this in mind it is probable that the daily intake of food was greater at $\mathrm{J}-60$ and $\mathrm{J}-70$ than at the other stations throughout most of the season. The relatively high values in June could have been 
Figure 17. Feeding periodicity of young-of-the-year blueback herring from the Potomac River on 24 and 25 July and 28 and 29 October 1968. Central horizontal line, mean; vertical line, range. S.R., sunrise; S.S., sunset. 


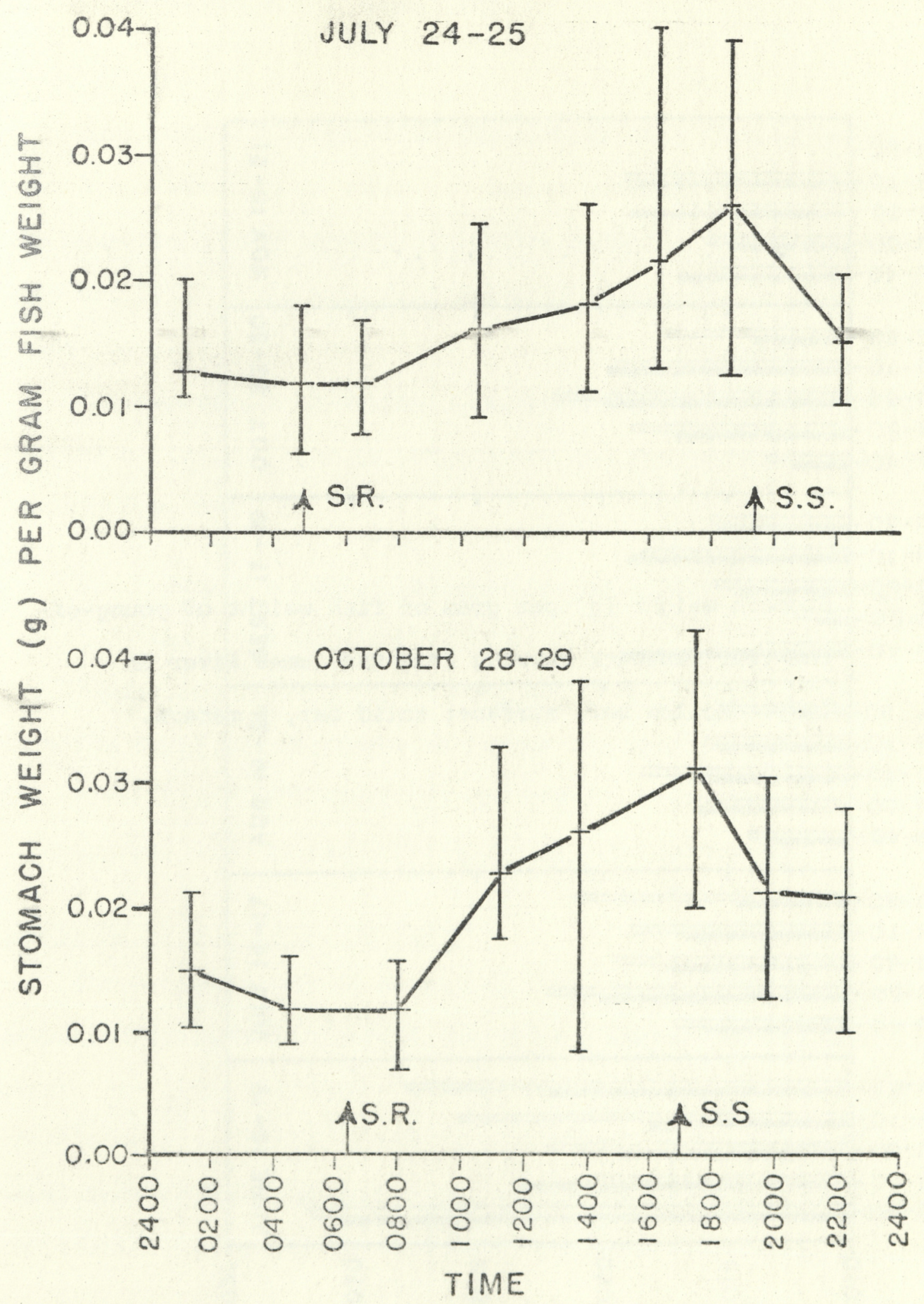


Figure 18. Stomach weight $(g)$ per gram of fish weight of young-ofthe-year blueback herring from the James River. in 1969. Hollow bar, surface; solid bar, 5 meters. 


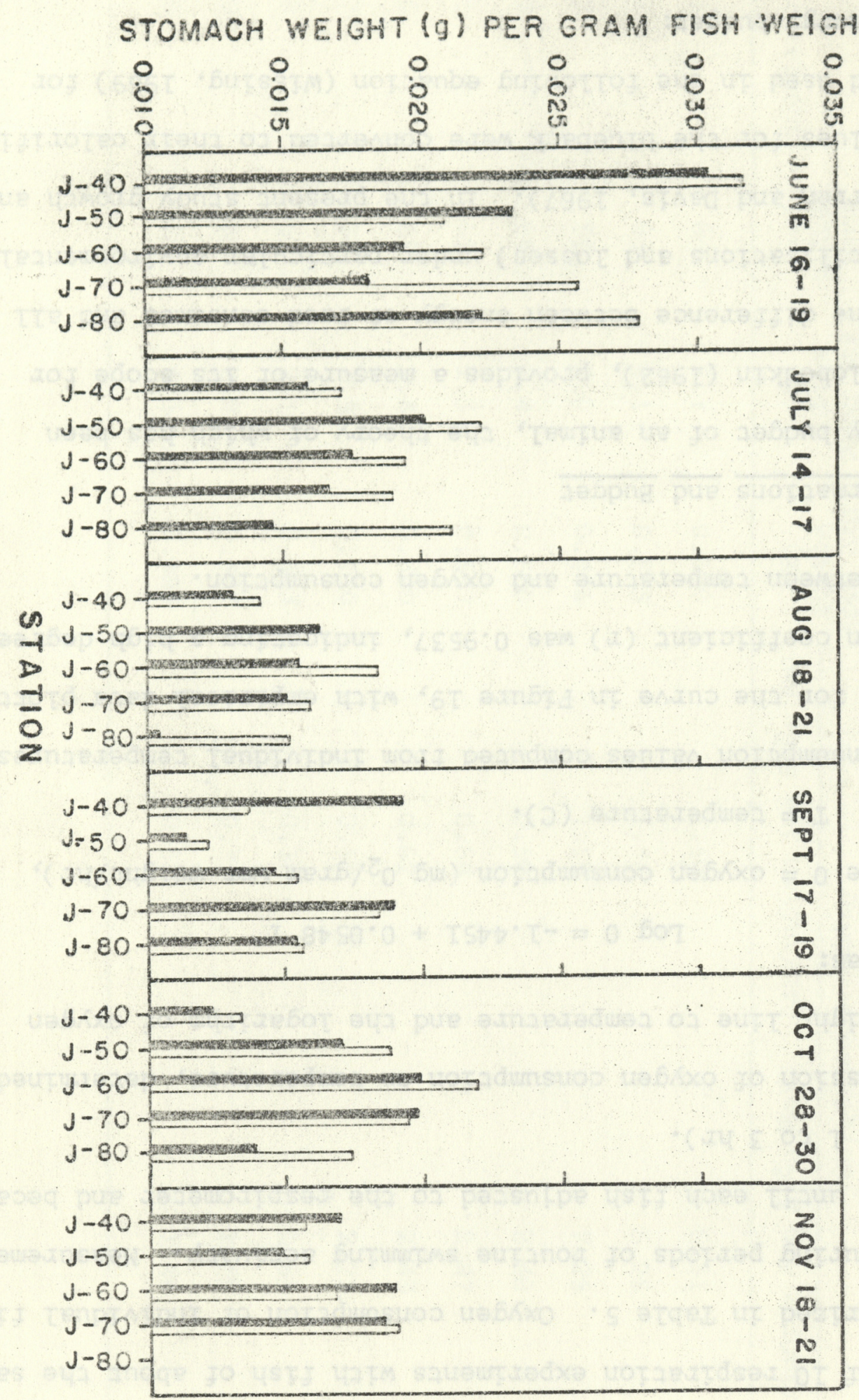


due to the possibility that stomachs of smaller fish were proportionally larger than stomachs of older fish.

Respiration

Results of 10 respiration experiments with fish of about the same size are summarized in Table 5. Oxygen consumption of individual fish was measured during periods of routine swiming activity. Measurernents were not begun until each fish adjusted to the respirometer and became quiet (usually 1 to 3 hr).

The regression of oxygen consumption on temperature, determined by fitting a straight line to temperature and the logarithm of oxygen consumption, was:

$$
\log 0=-1.4451+0.0548 \mathrm{~T}
$$

where $0=$ oxygen consumption ( $\mathrm{mg} \mathrm{O}_{2} / \mathrm{gram}$ wet weight/hr), and $T=$ temperature $(C)$.

Oxygen consunption values computed from individual temperatures were the basis for the curve in Figure 19, with empirical data plotted. The correlation coefficient $(r$ ) was 0.9537 , indicating a high degree of relationship between temperature and oxygen consumption.

\section{Energy Transformations and Budget:}

The energy budget of an animal, the theory of which has been presented by Slobodkin (1962), provides a measure of its scope for growth (ie., the difference between energy of food consumed and all other energy utilizations and losses) under particular environmental conditions (Warren and Davis, 1967). In the present study growth and respiration values for the blueback were converted to their calorific equivalents and used in the following equation (Wissing, 1969) for computing an energy budget: 
Table 5. Fork length, wet and dry body weight, water temperature, and oxygen consumption rate for young-of-the-year blueback herring from the James River

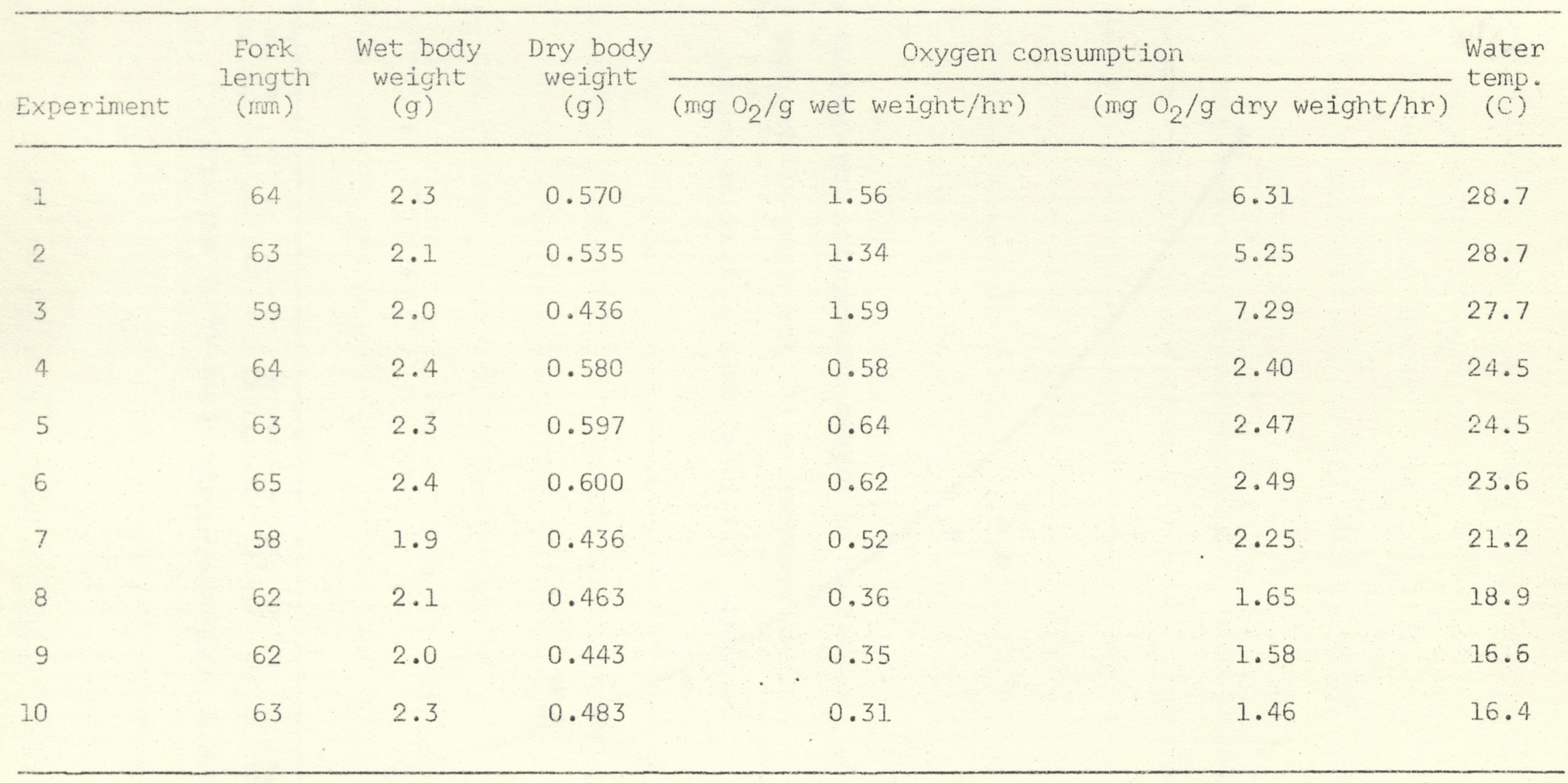


Eigure 19. Regression of oxygen consumption (ng $\mathrm{O}_{2} /$ gram wet weight/ hr) on temperature (c) for young-of-.the-year biueback herring. Empirical data plotted as points. 


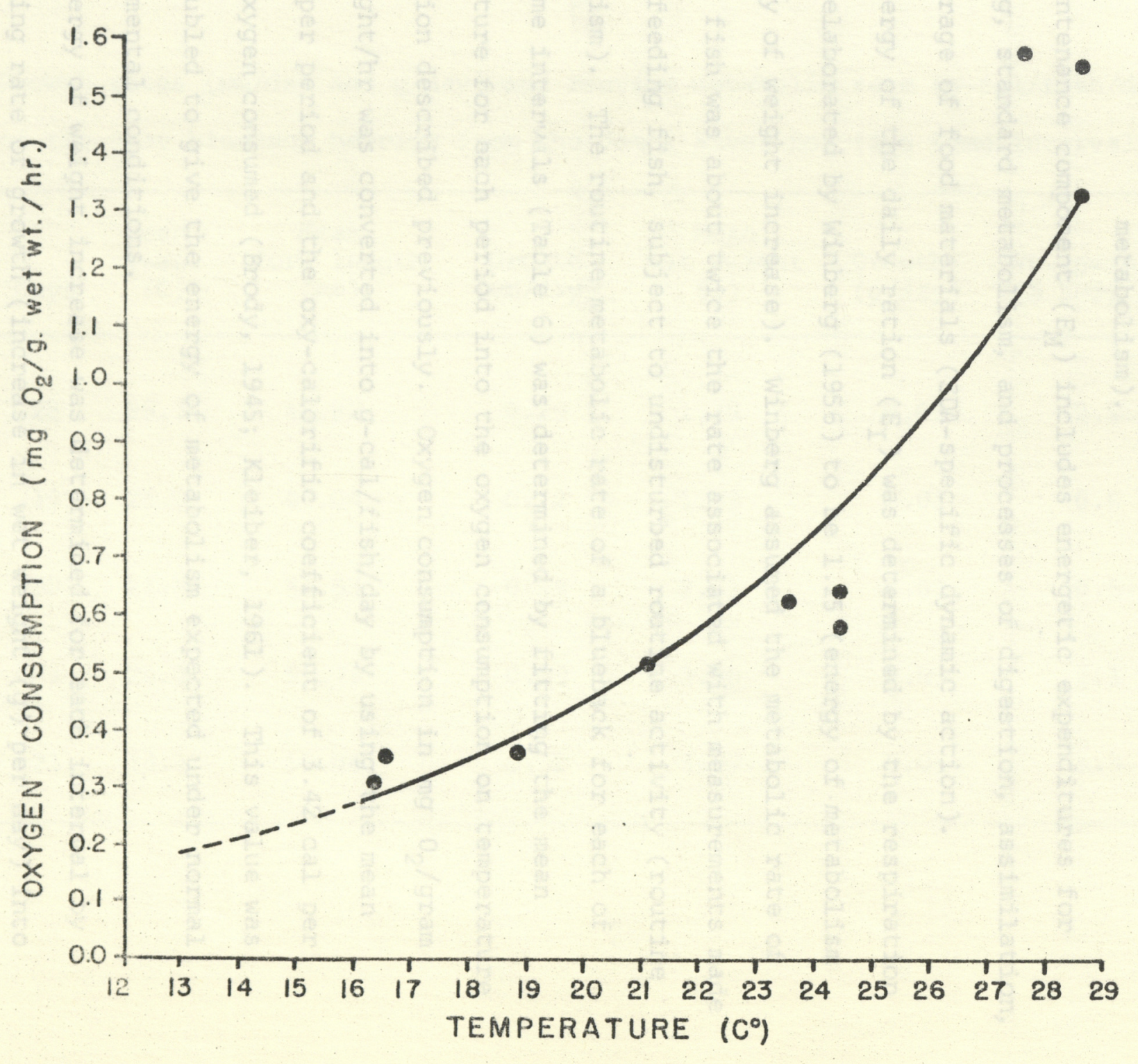


Table 6. Growth rates (mn/day and $g / d a y)$ and routine metabolic rate (g-cal/fish/day) for youngof-the-year blueback herring from the James River for five time intervals in 1969

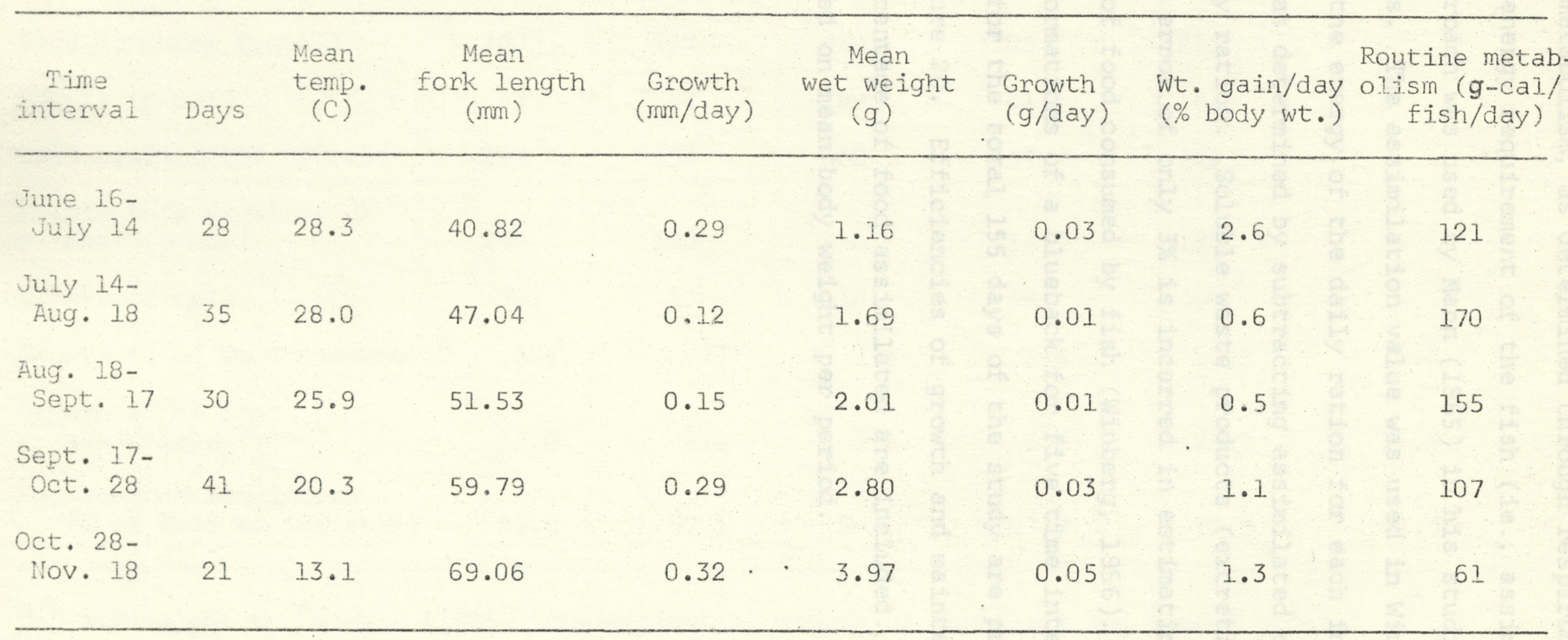


times the routine metabolism, as determined through respironetry, was assumed to be the energy requirement of the fish (ie., assimilated food energy). This approach was used by Mann (1965) in his studies of fish in the River Thames. The assimilation value was used in Winberg's formula to obtain the energy of the daily ration for each interval. Energy of egesta was determined by subtracting assimilated energy from energy of the daily ration. Soluble waste products (excretion) were not considered, but an error of only $3 \%$ is incurred in estimating the calorific content of food consumed by fish (Winberg, 1956).

Energy transformations of a blueback for five time intervals and the energy budget for the total 155 days of the study are presented in Table 7 and Figure 20. Efficiencies of growth and maintenance requirement as percentage of food assimilated are included. Fish biocontent was based on mean body weight per period. 
Table 7. Energy transformations (per day) of a young-of-the-year blueback herring for five time intervals in 1959

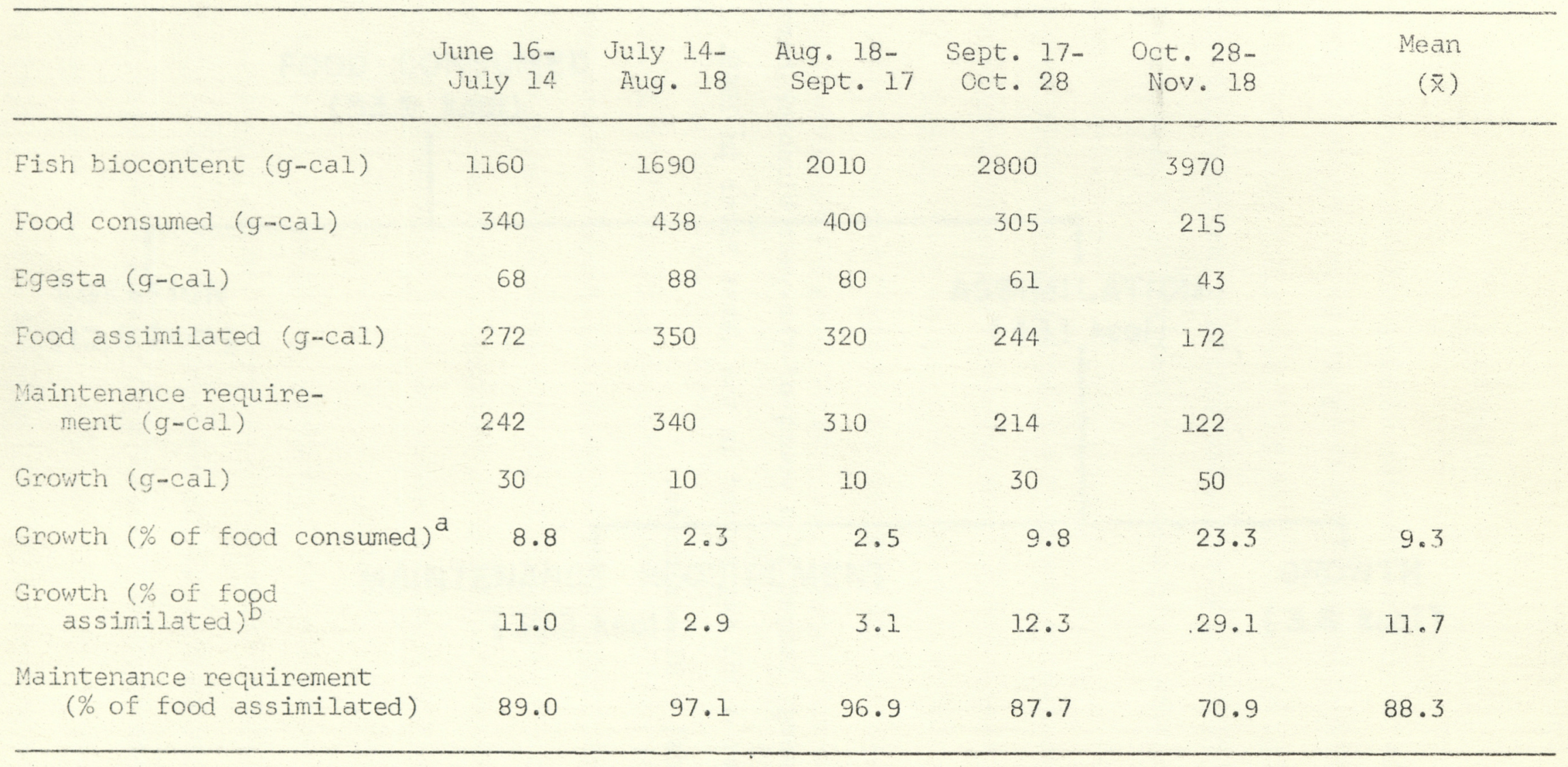

a,b Equivalent to Ivlev's (1945) "coefficient of growth of the first and second order," respectively. 
Figure 20. Energy budget of a young-of-the-year blueback herring for a 155 day period in the James River in 1969. kcal $=$ kilocalories . 


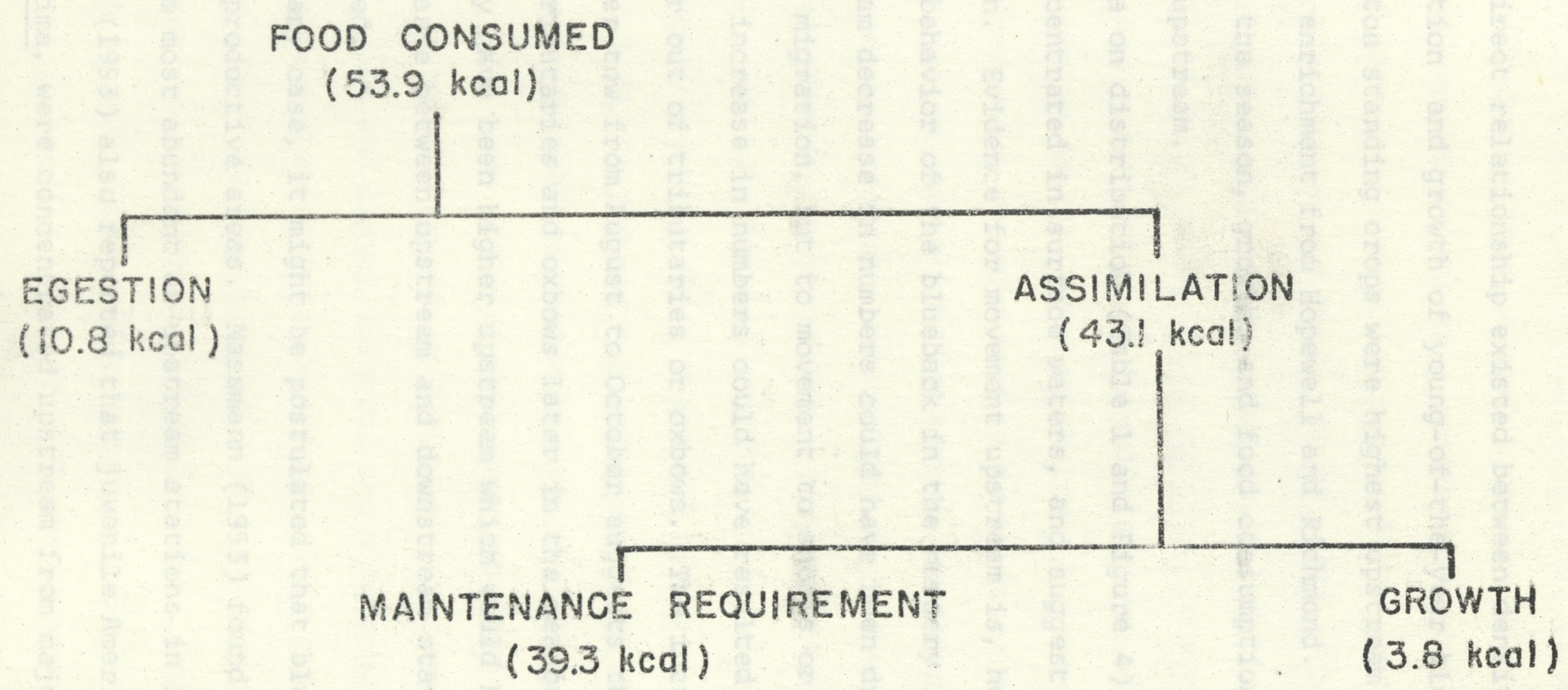




\section{DISCUSSION}

A direct relationship existed between density of zooplankton and distribution and growth of young-of-the-year blueback herring. Zooplankton standing crops were highest upstream due primarily to nutrient enrichment from Hopewell and Richmond. Abundance of bluebacks later in the season, growth, and food consumption were correspondingly highest upstream.

Data on distribution (Table 1 and Figure 4) show that bluebacks were concentrated in surface waters, and suggest a general upstream migration. Evidence for movement upstream is, however, circumstantial. because behavior of the blueback in the nursery is unknown. The downstrean decrease in numbers could have been due not only to an upstream migration, but to movement to shoals or tributaries. The upstream increase in numbers could have resulted from fish moving upstream or out of tributaries on oxbows. The increase in grand average number per tow from August to October suggests that fish were moving out of tributaries and oxbows later in the season. In addition, survival rates may have been higher upstream which would have caused differences in abundance between upstream and downstream stations to be more pronounced.

In any case, it might be postulated that bluebacks moved upstream to more productive areas. Massmann (1953) found young-of-the-year bluebacks most abundant at upstream stations in five Virginia estuaries. Massmann (1953) also reported that juvenile American shad, Alosa sapidissima, were concentrated upstream from major spawning areas, and suggested that they moved upstream on that upstream spawnings were 
subject to higher rates of survival.

Density of food in an animal's immediate surroundings determines the amount of food it can obtain in a short period and the energy costs of obtaining food. Thus, a useful measure of food as an environmental factor influencing growth of a predator is mean prey density over a period of tine long enough for measurable weight changes to occur in the predator (Warren and Davis, 1967). Allen (1951) and Horton (1961) showed a relationship between density of benthos and food consumption and growth of brown trout, Salmo trutta. Johnson (1961, 1965) demonstrated that growth rates of juvenile sockeye salmon, Oncorhynchus nerka, were related to density of zooplankton.

Environmental factors such as temperature and oxygen that influence food consumption and metabolism either physiologically or behaviorally, activity of the predator, and quality of food also relate to growth and must be considered (Brett, 1970). Temperature and dissolved oxygen were essentially the same between stations on a seasonal basis: J-40, $24.0 \mathrm{C}$ and $6.2 \mathrm{mg} /$ liter; J-50, $23.5 \mathrm{C}$ and $4.5 \mathrm{mg} / \mathrm{liter}$ J-60, $23.5 \mathrm{C}$ and $5 . \mathrm{I}$ $\mathrm{mg} /$ Iiter; J-70, 24.2 C and $4.6 \mathrm{mg} /$ liter; J-80, $23.7 \mathrm{C}$ and $5.9 \mathrm{mg} / 1 \mathrm{iter}$. Therefore it is assumed that activity of fish was similar between stations. The same kinds of prey were consumed at each station (Figures 10 to 15 ), except at J-80 where littoral copepods (Eucyclops agilis), adult and larval insects, and oligochaetes were consumed to a greater extent than at othen stations. This could explain why J-80 fish were about the same size as $J$-70 fish even though density of zooplankton was considerably lower at J-80. Food intake was less at J-80 than at J-70 (I'igure 18), but this could be explained by differences in feeding behavior. Bluebacks at J-80 may have been feeding on adult and larval insects primarily in the evening, so 
stomachs collected at midday would have contained less food than stomachs from the other stations.

Comparatively high growth rates of bluebacks at upstream stations (Figure 5) could therefore be attributed primarily to differences in prey density and levels of intra- and interspecific competition between upstream and downstream stations. Standing crops of zooplankton, including those most important in the diet, were higher at J-60 and J-70 (Figures 7 to 9) than at $\mathrm{J}-40$ and $\mathrm{J}-50$, and food consumption was correspondingly greater at $J-60$ and $J-70$ (Figure 18) than at other stations. Conpetition was apparently greater downstream than upstream. Selection for nauplii at J-40 in lieu of "preferred" prey supports this. Interspecific competition was primarily from the anchovy, Anchoa mitchilli, which feeds on copepods (Hildebrand and Schroeder, 1928). Relatively large numbers of anchovies (maximum of 462 per tow) were captured at J-40 and J-50 throughout the study. Anchovies were as numerous as bluebacks at J-40 in July and were more abundant than bluebacks at J-40 in August, October, and November. Laaman (1969) related reduced growth rates of coho salmon, Oncorhynchus kisutch, to interspecific competition from steelhead trout, Salmo gairdneri. The mean size of upstream fish may also have been influenced if there was an upstream migration and only largen fish were involved.

Decrease in condition (K) from August to November (Figure 6) may have been due to lower food availability as a result of the flood (Figure 9), to the nomal seasonal decline in zooplankton populations, and to increased intraspecific competition due to increased numbers of bluebacks in the channel (Table 1). Berg and Grimaldi (1966) found that condition of coregonids was directly related to abundance of prey. Food habits of bluebacks in the James River were similar to those 
of bluebacks from the Cape Fear River (Davis and Cheek, 1966), where sma11. crustaceans made up the major portion of the diet. Bluebacks in the James exhibited a selective feeding behavior (Figures 10 to 16 ). Copepod nauplii, although they constituted on the average almost half (46.9\%) of the plankton, were strongly selected against, except at J-40 where plankton density was relatjvely low and competition for food was apparently high. copepodites were moderately to weakly selected for, selection coincided with their relative abundance in the plankton, and mean electivity decreased in time. Adult copepods were moderately to strongly selected for even though they made up only a small percentage of the plankton (5.9\%). Selection increased with size of fish. Bosmina longirostnis-coregoni was generally selected against except when relatively abundant in the plankton. Mean electivity was weak and decreased with size of fish. Diaphanosoma brachyurum was usually selected against.

The selective phenomenon was discussed in detail by IVlev (196I). Selective feeding has been observed in American smelt, Osmerus mordax (Reif and Tappa, 1966); rainbow trout, Salmo gairdneri, and yellow perch, Perca flavescens (Gailbraith, 1967); walleye, Stizostedion vitreum (Houde, 1967); gizzand shad, Dorosoma cepedianum (Cramex and Marzolf, 1970); bigmouth buffalo, Ictiobus cyprinellus (Starostka and Applegate, 1970); alewife, Alosa pseudoharengus (Brooks and Dodson, 1965; Wells, 1970; Hutchinson, 1971); and blueback herring (Brooks and Dodson, 1965).

Degree of food selectivity by plankton-feeding fish largely depends upon size, abundance, and mobility of food organisms. Selection is accomplished either by particle selection or by indiscriminant filtering, in which case spacing between gill rakens determines size of organisms captured. Smaller organisms which pass through the gill rakers on avoid 
ingestion are not utilized. The result is a greater percentage of large organisms in the stomach compared to percentage in the plankton (Starostkda and Applegate, 1970). Nauplii were selected for by bluebacks in the James River at $J-40$ which indicates that they could be retained by the gill rakers. If fish were routinely filter-feeding, nauplii would have appeared in stomachs taken at the other stations. However, nauplii were not eaten extensively, even though they were the most abundant item in the plankton, which indicates that filter-feeding was unlikely. Bluebacks in the laboratory selected Artemia nauplij. individually. Bluebacks were apparently selecting individual organisms, and size, abundance, and mobility of prey probably all played a role in the selective mechanism. Adult copepods (Eurytemora affinis, 1.0 to $1.5 \mathrm{~mm}$; Cyclops vernalis, 0.8 to $1.8 \mathrm{~mm}$ Canthocamptus robertcokeri, 0.6 to $0.8 \mathrm{~mm}$; from Ward and Whipple, 1959) were most strongly selected for, evidently on the basis of size. Intenmediate sized copepodites were moderately to weakly selected for. The relatively small Bosmina longirostriswcoregoni (0.25 to $0.31 \mathrm{~mm}$; from Hutchinson, 1971 ) was selected against except when its percentage in the plankton was relatively high, which suggests that selection was influenced by relative abundance. The selection against Diaphanosoma brachyurum, even though it is larger ( 0.4 to $0.9 \mathrm{~mm}$; from Ward and Whipple, 1959) than B. Iongirostris-coregoni, suggests that mobility was important. D. brachyurum may be an erratic swimmer which would make it Iess susceptible to predation than the other species. Cramer and Marzolf (1970) noted that gizzand shad selected against $\underline{D}$. brachyurum.

Ivlev (1961) discussed the positive selection of larger, available food organisms by predatory fishes. Planktivorous fish in lakes first select larger prey species and then largest individuals of each species 
(Brooks, 1968). Brooks (1968) observed in laboratory experiments that when nauplii, copepodites, and adults of Diaptornus minutus were fed to juvenile alewife, adults were eaten first, then copepodites, and finally nauplii.

Gailbraith (1967) showed that rainbow trout and yellow perch selected large Daphnia pulex over $1.3 \mathrm{~mm}$ long. A comparison of gill raker spacings in rainbow trout to size of prey indicated that smaller plankters should have been retained if filtration was the only mechanism involved.

Brooks and Dodson (1965) noted size differences in zooplankton populations where alewife and blueback herring were abundant. Relatively lange zooplankton species were never dominant in lakes having Alosa, whereas they were always dominant in lakes devoid of Alosa. Population declines of Daphnia have been associated with size-selective predation by young-ofthe-yean threadin shad, Dorosoma petenense (Applegate and Mullan, 1969). Hall demonstrated that large D. pulex were selected and smallen Daphnia galeata mendotae were rejected by adult cisco, Leucichthys artedi, and black crappie, Pomoxis nigromaculatus.

Food selection, and the evolutionary strategy implied by j.ts existence, is normally expected only in those situations where loss of efficiency due to not utilizing all avajlable resources is negligable in relation to efficiency gained by specialization (MacArthur and Levins, 1964). Thus, a predator will feed in a manner which will produce an optimum return for amount of energy expended.

The efficiency with which a species collects its food is an important factor governing its success in competition with other organisms at a given trophic level. Generaliy, in any ecosystem, the dominant species at each trophic level can be considered to be most efficient in utjlizing the limiting resource (Cramer and Marzolf, 1970). In the James River the 
blueback can be considered dominant since they constituted $76 \%$ of the total number of fish captured during the study. That they selected large food items and excluded smaller forms strongly suggests that they picked larger organisms individually by choice. This behavioral selection seems reasonable in view of the relative size of predator and prey. The only energetically economical way to eat large food items would be to pick them individually, because filter feeding would yield few large organisms. Under intensive size-selective predation, abundance of lange dominant species decreases. Lessened competition from large species permits numbers of small species to increase, even though the latter are preyed upon as larger species become scarce (Brooks, 1968, 1969). This obviously occurred in the James River. Numbers of adult copepods were considerably less than numbers of Bosmina longinostris-coregoni. (Figures 7 and 8 ) over the entire season, particularly at the surface where bluebacks were concentrated (Figure 4) and feeding was most intense (Figure 18). The vertical migratory behavion of copepods may have contributed to their decreased abundance at the surface, but predation was obviously intense because copepods were eaten.

Smith (1963) concluded that removal of young individuals more effectively reduces population density than does removal of aduits. Thus, if fish prey on both mature and immature forms, numbers of surviving adults may be insufficient to sustain the population. This was apparently the case. in the James River since both immature and mature copepods were consumed. Intensive predation on large dominant copepods resulted in dominance of the smaller Bosmina longirostriscoregoni. This smaller form filled the niche that would nomally be occupied by the dominant copepods. Brooks and Dodson (1965) and Gailbraith (1967) noted that when numbers of Daphnia were reduced by 
selective predation, Bosmina became dominant. Reif and Tappa (1966) attributed the elimination of Daphnia pulex from Harveys Lake, Conn., and the survival of $\mathrm{B}$. Iongirostris and Daphnia dubea to selective predation by American smelt.

Size selective predators feed using visual cues (Dodson, 1970) which would explain why bluebacks feed primarily during daylight (Figure 17). Turbidity probably reduces transmission of moonlight to a point where the fish can no longen see their prey. Massmann (1963) found that juvenile American shad in the Pamunkey and Mattaponi Rivers, Virginia, fed duning the day, stomachs reaching maximurn fullness in early evening,

Mean efficiency of maintenance requirement (percentage of food assimilated (Table 7) was within ranges computed from laboratory studies of other species: cutthroat trout, Salmo clarki, 56.7 to $93.4 \%$ (Brocksen, et al., 1968); longear sunfish, Lepomis megalotis megalotis, 66.7 to $95.3 \%$ (Gerking, 1952). However, maintenance efficiencies appear to be unusual.1y high for the second two tine intervals (97.1 and 96.9\%). These figures may not be unrealistic if one considers that the blueback is normally an active and fast-swimming fish. Blueback schools held in aquaria were constantly in motion. Swimming was rapid and schools never held position. Individual fish in the respirometer were not affected by removal from the school. They were no more active on excited than when schooling. The combined effect of temperature and activity could account for the relatively high maintenance requirement. Note that weight gain as percentage of body weight (Table 6) decreased from June-July to a low of $0.5 \%$ in August-September, and then increased to October-November. Higher growth efficiencies from September to November were due primarily to lower maintenance costs resulting from lower temperatures. The ration from October-November was less than the maintenance requirements 
from June to september. This suggests there are temperatures at which maintenance costs may be low but at which fish are still metabolically able to utilize food efficiently for growth. Under these circumstances growth efficiencies will be high (Warren and Davis, 1967). As growth increased, the daily ration and condition (Figure 6) decreased from August to November, due probably to decreasing food availability (Figure 9) and increased competition (Table 1). Warren and Davis (1967), using unpublished data from Brocksen, showed that cutthroat trout had a higher growth efficiency in late winter than in spring due to lower maintenance costs. 
SUMMARY

A direct relationship existed between density of zooplankton. and distribution and growth of young-of--the-year blueback herring. Zooplankton standing crops were highest upstream where abundance later in the season, growth, and food consumption were correspondingly highest.

Blueback herring were concentrated at the surface. The downstream decrease and upstream increase in abundance suggested an upstream migration to more productive regions of the river.

Increased growth rates upstream were related to relatively high zooplankton standing crops. Interspecific competition for food was greater downstream than upstream. A decrease in condition $(K)$ after flooding from Hurricane camille may have been due to a decrease in food and an increase in competition from greater numbers of bluebacks in the channel.

Bluebacks fed primarily on copepods, but cladocerans were also important. A selective feeding behavion was demonstrated, and strength of selection (electivity) was related to size of prey. Selection was strongest for adult copepods and weakest for copepod nauplii. Intense predation on adult copepods resulted in dominance of the smaller Bosmina longirostris-coregoni. Feeding occurred only during daylight indicating that visual cues were important.

Energy transformations of young-of-the-year blueback herring computed from growth and respirometry data show that the maintenance requirement was high and growth was low during summer, and that growth increased as temperature decreased due to lower maintenance 
Appendix A

Zooplankton Standing Crops 
Table Al. Zooplankton standing crops as number per liter. Percentage of total number of organisms per liter in parentheses. Date: 16-19 June 1969. S, surface; 5m, 5 meters

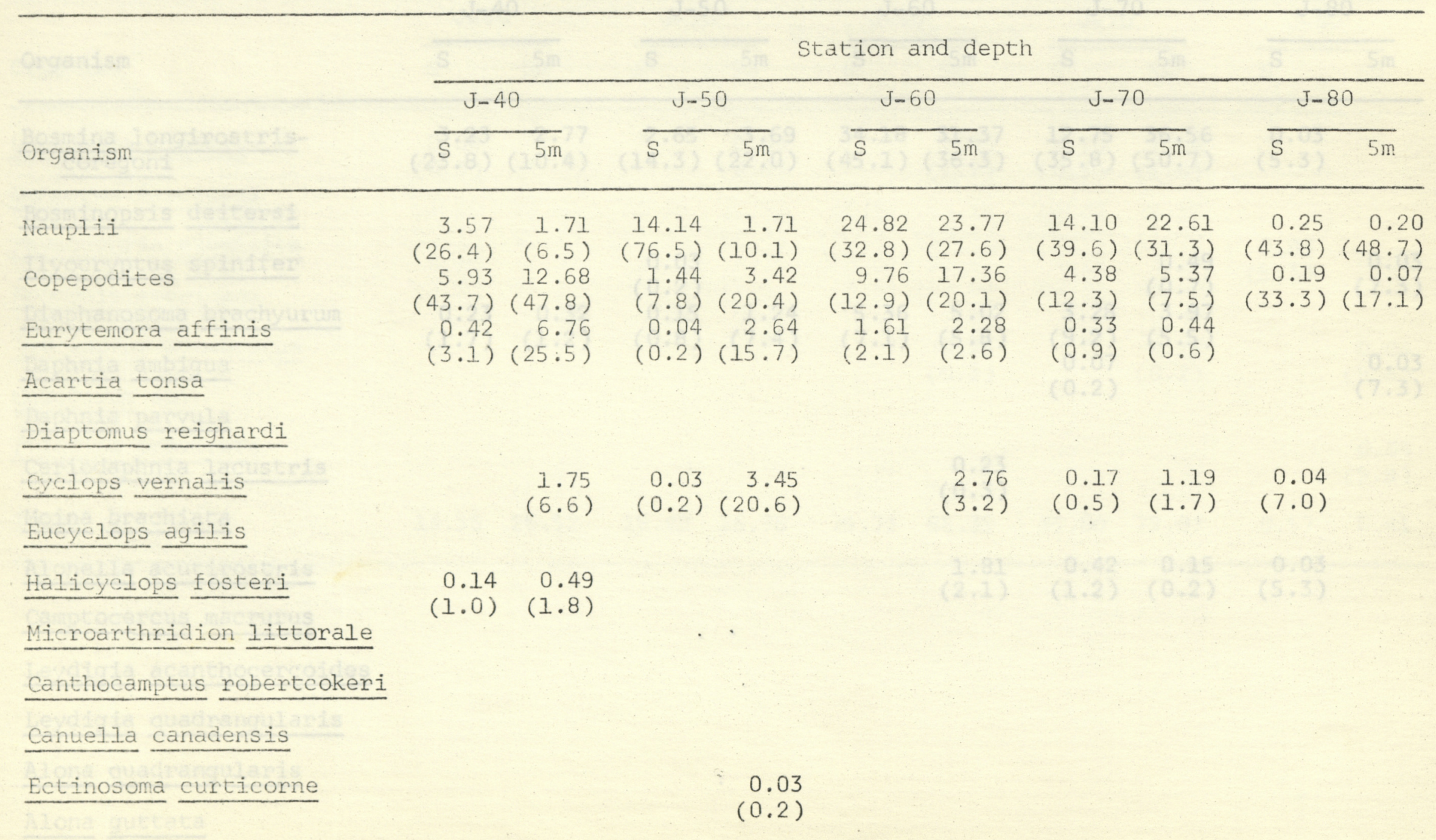


Table Al. (Continued).

Station and depth

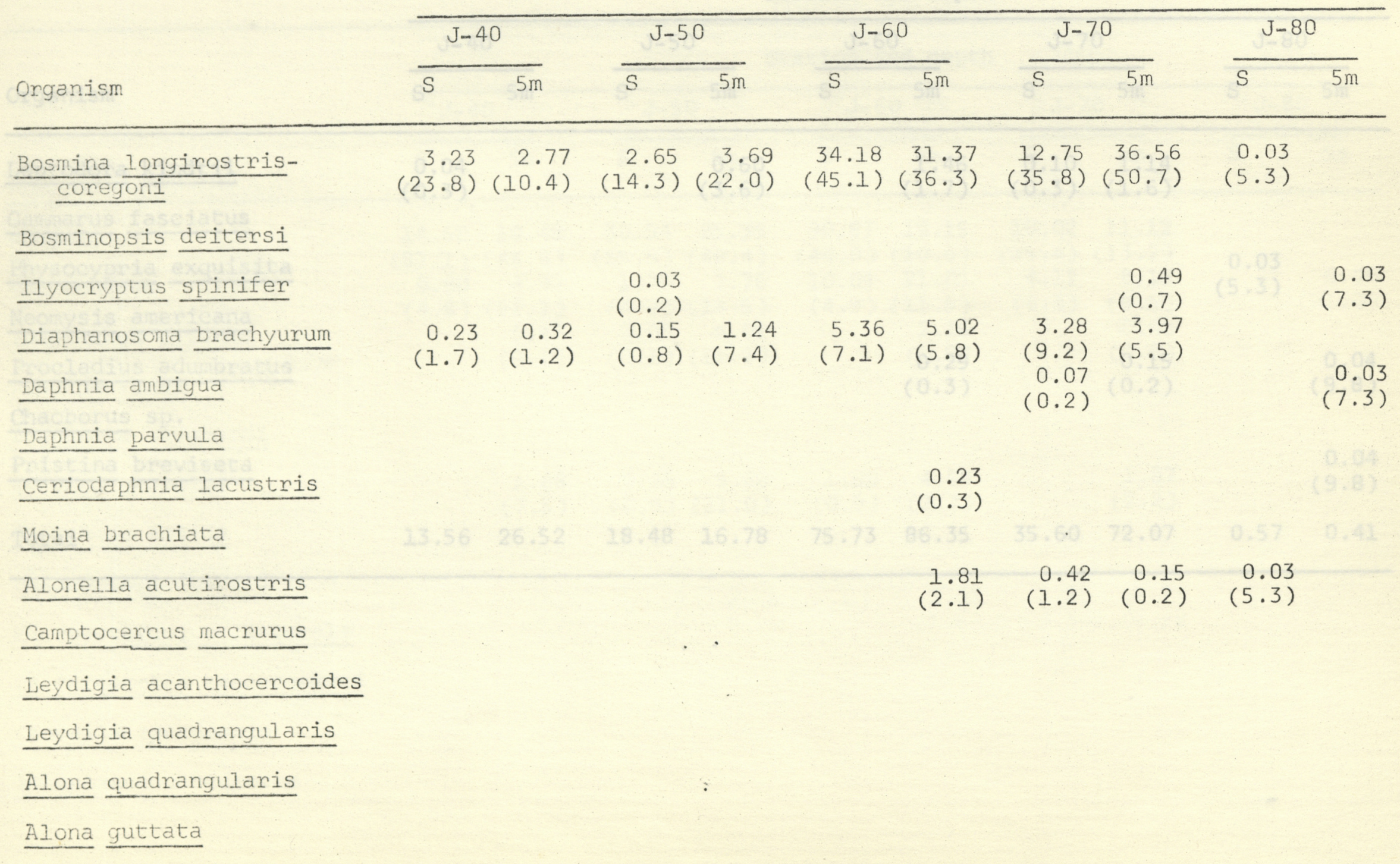


Table Al. (continued).

\begin{tabular}{|c|c|c|c|c|c|c|c|c|c|c|}
\hline \multirow[b]{3}{*}{ Organism } & \multicolumn{10}{|c|}{ Station and depth } \\
\hline & \multicolumn{2}{|c|}{$\mathrm{J}-40$} & \multicolumn{2}{|c|}{$\mathrm{J}-50$} & \multicolumn{2}{|c|}{$\mathrm{J}-60$} & \multicolumn{2}{|c|}{$\mathrm{J}-70$} & \multicolumn{2}{|l|}{$\mathrm{J}-80$} \\
\hline & S & $5 m$ & $S$ & $5 m$ & $S_{y-6}$ & $5 m$ & S & $5 m$ & $S$ & $5 m$ \\
\hline Leptodora kindtii & $\begin{array}{r}0.04 \\
(0.3)\end{array}$ & & 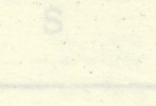 & $\begin{array}{r}0.60 \\
(3.6)\end{array}$ & & $\begin{array}{r}1.46 \\
(1.7)\end{array}$ & $\begin{array}{r}0.10 \\
(0.3)\end{array}$ & $\begin{array}{r}1.14 \\
(1.6)\end{array}$ & & 5 \\
\hline Gammarus fasciatus & & & & & & & $20=02$ & $32+22$ & & \\
\hline $\begin{array}{l}\text { Physocypria exquisita } \\
\text { Neomysis americana }\end{array}$ & & & & & 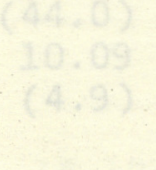 & & & & $\begin{array}{r}0.03 \\
(5.3)\end{array}$ & 20209 \\
\hline Procladius adumbratus & & & & & & $\begin{array}{r}0.29 \\
(0.3)\end{array}$ & & $\begin{array}{r}0.15 \\
(0.2)\end{array}$ & & $\begin{array}{r}0.04 \\
(9.8)\end{array}$ \\
\hline Chaoborus sp. & & & & & & & & & & \\
\hline Pristina breviseta & & & & & & & & & & $\begin{array}{r}0.04 \\
(9.8)\end{array}$ \\
\hline Total ops a s & 13.56 & 26.52 & 18.48 & 16.78 & 75.73 & 86.35 & $35 \cdot 60$ & 72.07 & 0.57 & 0.41 \\
\hline
\end{tabular}


Table A2. Zooplankton standing crops as number per liter. Percentage of total number of organisms per liter in parentheses. Date: 30 June 1969. S, surface; 5m, 5 meters

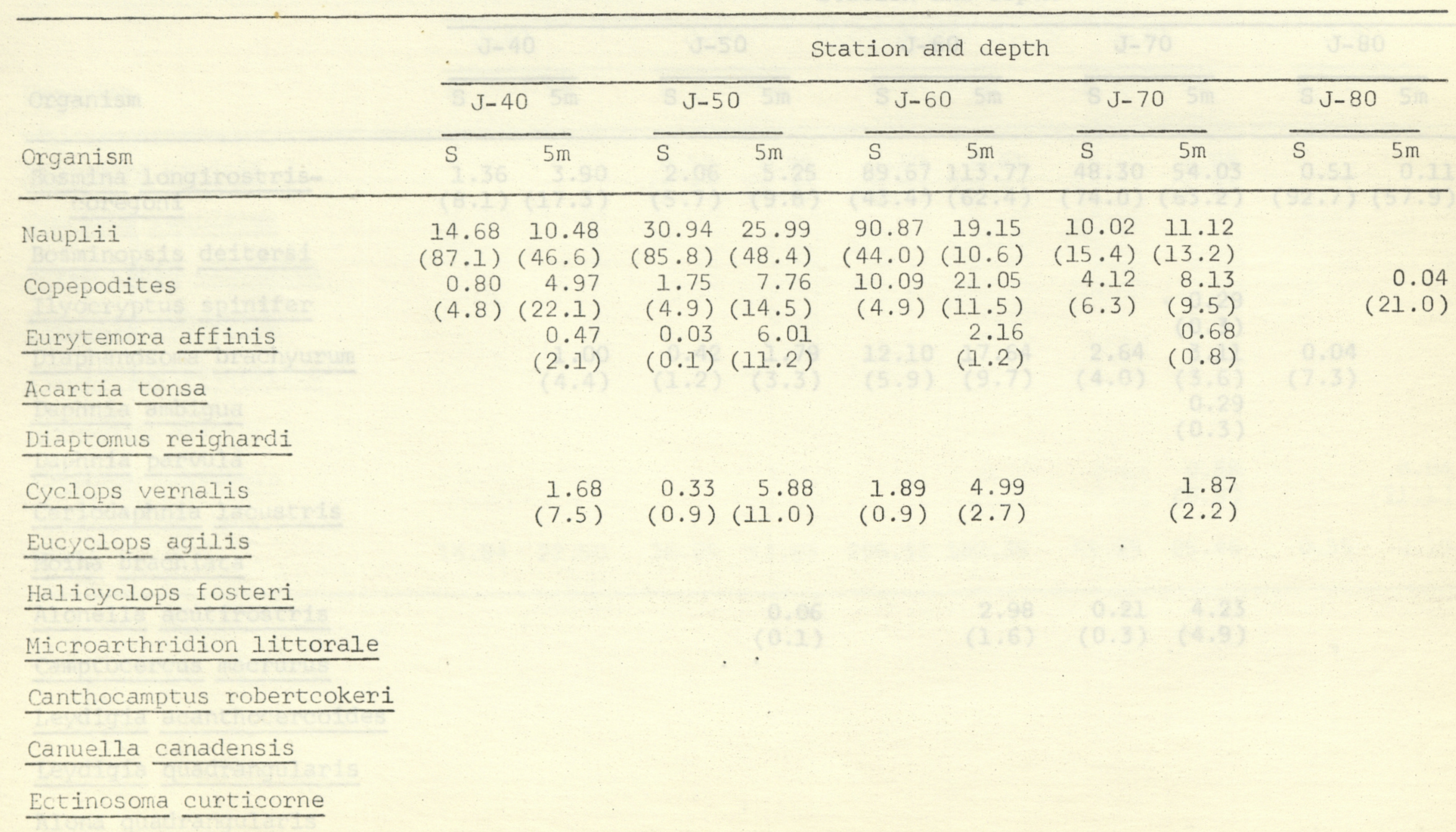




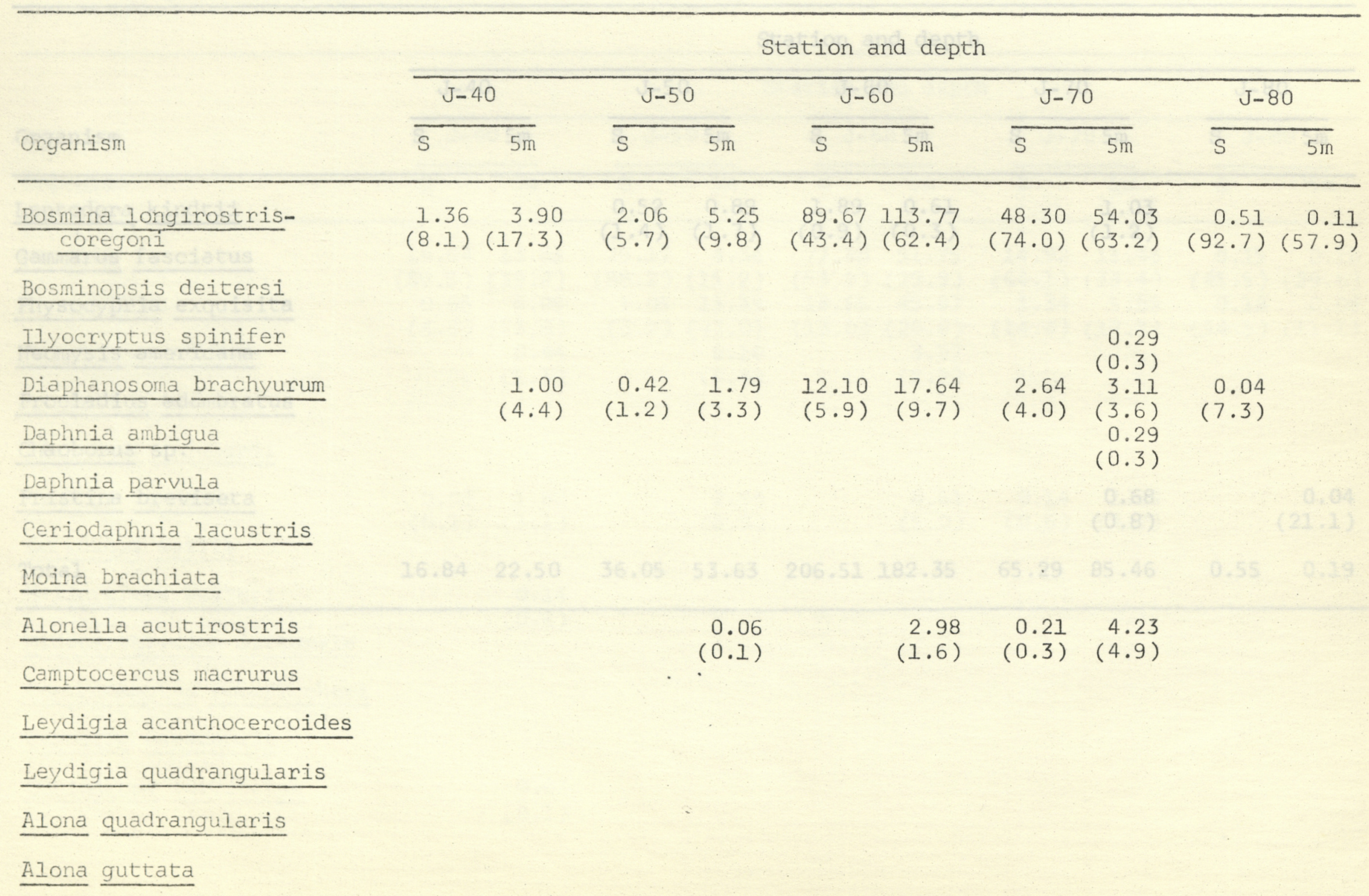


Table A2. (Continued).

Station and depth

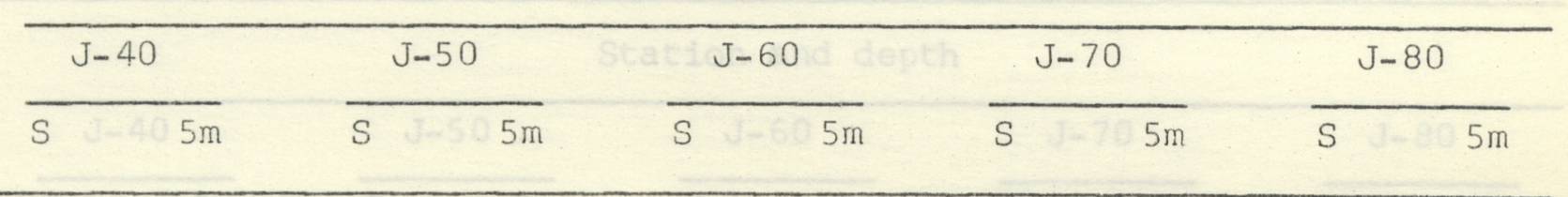

Leptodora kindtii

$\underline{\text { Gammarus fasciatus }}$

Physocypria exquisita

Neomysis americana

Procladius adumbratus

Chaoborus sp.

Pristina breviseta

$\begin{array}{rrrrr}0.52 & 0.89 & 1.89 & 0.61 & 1.03 \\ (1.4) & (1.7) & (0.9) & (0.3) & (1.2)\end{array}$

Total

$\begin{array}{lllllllll} & & & & 0.68 & 0.04 \\ 16.84 & 22.50 & 36.05 & 53.63 & (0.8) & & (21.1) \\ \end{array}$


Table A3. Zooplankton standing crops as number per liter. Percentage of total number of organisms per liter in parentheses. Date: $14-17$ July 1969. S, surface; $5 \mathrm{~m}, 5$ meters

\begin{tabular}{|c|c|c|c|c|c|c|c|c|c|c|}
\hline \multirow[b]{3}{*}{ Organism } & \multicolumn{2}{|c|}{$0 \div 30$} & \multicolumn{4}{|c|}{ Station and depth } & \multicolumn{2}{|c|}{$y=70$} & \multicolumn{2}{|c|}{3580} \\
\hline & \multicolumn{2}{|c|}{$\mathrm{J}-40$} & \multicolumn{2}{|c|}{$\mathrm{J}-50$} & \multicolumn{2}{|c|}{$\mathrm{J}-60$} & \multicolumn{2}{|c|}{$\mathrm{J}-70$} & \multicolumn{2}{|c|}{$\mathrm{J}-80$} \\
\hline & S & $5 \mathrm{~m}$ & S & $5 \mathrm{~m}$ & S & $5 \mathrm{~m}$ & S & $\begin{array}{r}5 \mathrm{~m} \\
\end{array}$ & $S$ & $5 m$ \\
\hline $\begin{array}{l}\text { Nauplii } \\
\text { Copepodites } \\
\text { Eurytemora affinis } \\
\text { Acartia tonsa }\end{array}$ & $\begin{array}{r}14.64 \\
(89.5) \\
0.66 \\
(4.0)\end{array}$ & $\begin{array}{r}13.81 \\
(39.4) \\
8.05 \\
(23.0) \\
0.44 \\
(1.3)\end{array}$ & $\begin{array}{r}29.17 \\
(88.2) \\
1.05 \\
(3.2)\end{array}$ & $\begin{array}{r}4.36 \\
(15.2) \\
13.39 \\
(47.0) \\
0.10 \\
(0.4)\end{array}$ & $\begin{array}{r}77.48 \\
(53.9) \\
18.65 \\
(13.0)\end{array}$ & $\begin{array}{r}51.75 \\
(29.9) \\
45.87 \\
(26.6) \\
3.97 \\
(2.3)\end{array}$ & $\begin{array}{r}14.92 \\
(64.1) \\
3.34 \\
(14.4)\end{array}$ & $\begin{array}{r}11.46 \\
(33.4) \\
5.89 \\
(17.3)\end{array}$ & $\begin{array}{r}0.15 \\
(45.5) \\
0.18 \\
(54.5)\end{array}$ & $\begin{array}{r}0.16 \\
(29.6) \\
0.06 \\
(11.1)\end{array}$ \\
\hline Diaptomus reighardi & & & & & & & & & & \\
\hline $\begin{array}{l}\text { Cyclops vernalis } \\
\text { Eucyclops agilis }\end{array}$ & $\begin{array}{r}0.03 \\
(0.2)\end{array}$ & $\begin{array}{l}1.09 \\
(3.1)\end{array}$ & & $\begin{array}{r}2.53 \\
(8.9)\end{array}$ & & $\begin{array}{r}8.61 \\
(5.0)\end{array}$ & $\begin{array}{r}0.14 \\
(0.6)\end{array}$ & $\begin{array}{r}1.59 \\
(4.7)\end{array}$ & & \\
\hline $\begin{array}{l}\text { Halicyclops fosteri } \\
\text { Microarthridion littorale }\end{array}$ & & $\begin{array}{r}0.14 \\
(0.4)\end{array}$ & & & & & & & & \\
\hline $\begin{array}{l}\text { Canthocamptus robertcokeri } \\
\text { Canuella canadensis }\end{array}$ & & & & . & & & & & & \\
\hline Ectinosoma curticorne & & $\begin{array}{r}0.03 \\
(0.1)\end{array}$ & & & & & & & & \\
\hline
\end{tabular}


Table A3. (Continued).

Station and depth

Organism

$\frac{\mathrm{J}-40}{\mathrm{~S} 5 \mathrm{~m}} \quad \frac{\mathrm{J}-50}{\mathrm{~S} 5 \mathrm{~m}} \quad \frac{\mathrm{J}-60}{\mathrm{~S} 5 \mathrm{~m}} \quad \frac{\mathrm{J}-70}{\mathrm{~S}}$

Bosmina longirostriscoregoni

$\begin{array}{rrrrrrrr}0.35 & 8.63 & 2.00 & 3.78 & 33.78 & 37.78 & 3.05 & 12.64 \\ (2.1) & (24.7) & (6.1) & (13.3) & (23.5) & (21.9) & (13.1) & (37.1)\end{array}$

Bosminopsis deitersi

Ilyocryptus spinifer

Diaphanosoma brachyurum

Daphnia ambigua

$\begin{array}{rrrrrrrr}0.69 & 2.78 & 0.81 & 3.90 & 8.83 & 18.39 & 1.82 & 0.17 \\ (0.5) & 2.17 \\ (4.2) & (8.0) & (.25) & (13.7) & (6.1) & (10.7) & (7.8) & (6.4)\end{array}$

Daphnia parvula

Ceriodaphnia lacustris

Moina brachiata

Alonella acutirostris

Camptocercus macrurus

$\begin{array}{lll}0.17 & 4.45 \quad 5.15\end{array}$

$(0.6) \quad(3.1) \quad(3.0)$

0.20

Leydigia acanthocercoides

Leydigia quadrangularis

Alona quadrangularis

Alona guttata 
Table A3. (Continued).

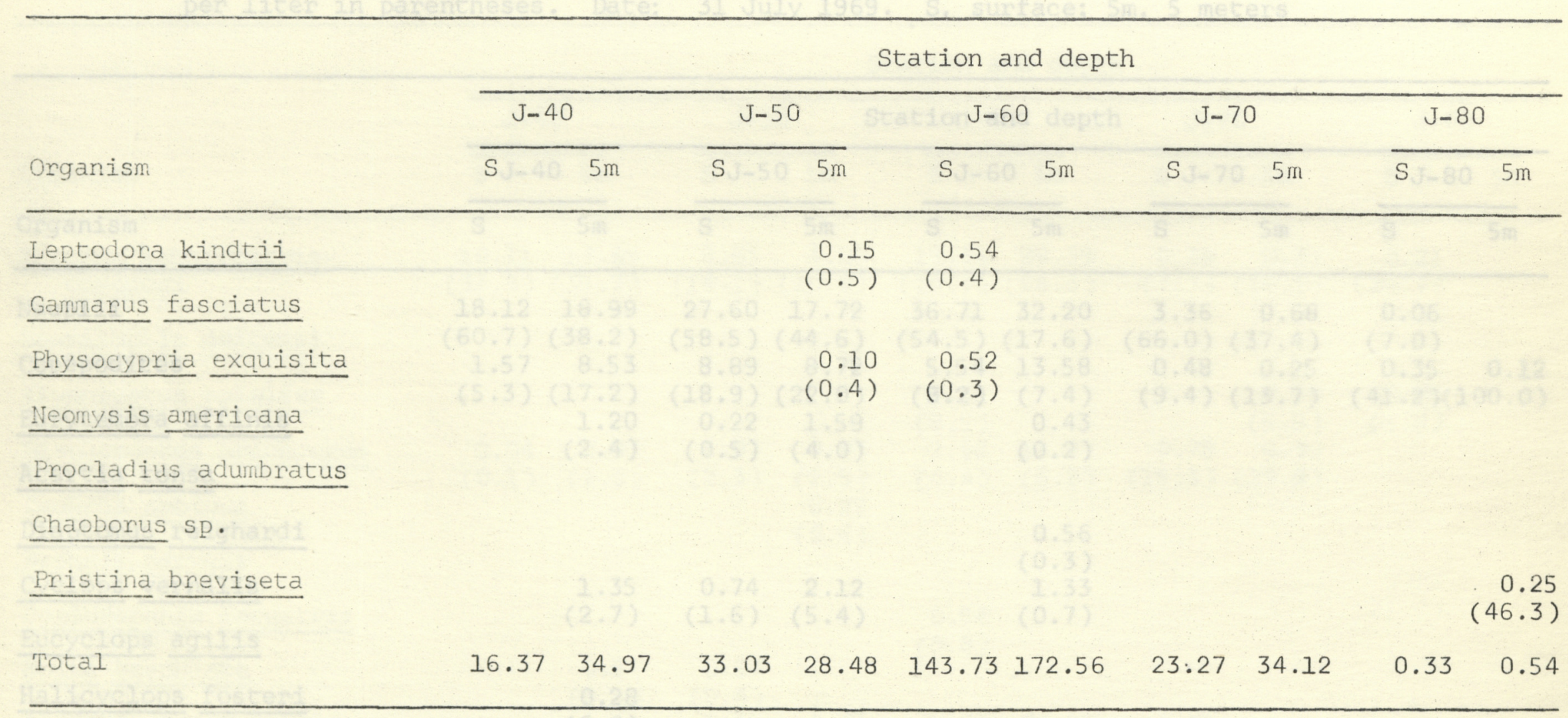


Table A4. Zooplankton standing crops as number per liter. Percentage of total number of organisms per liter in parentheses. Date: 31 July 1969. S, surface; $5 \mathrm{~m}$, 5 meters

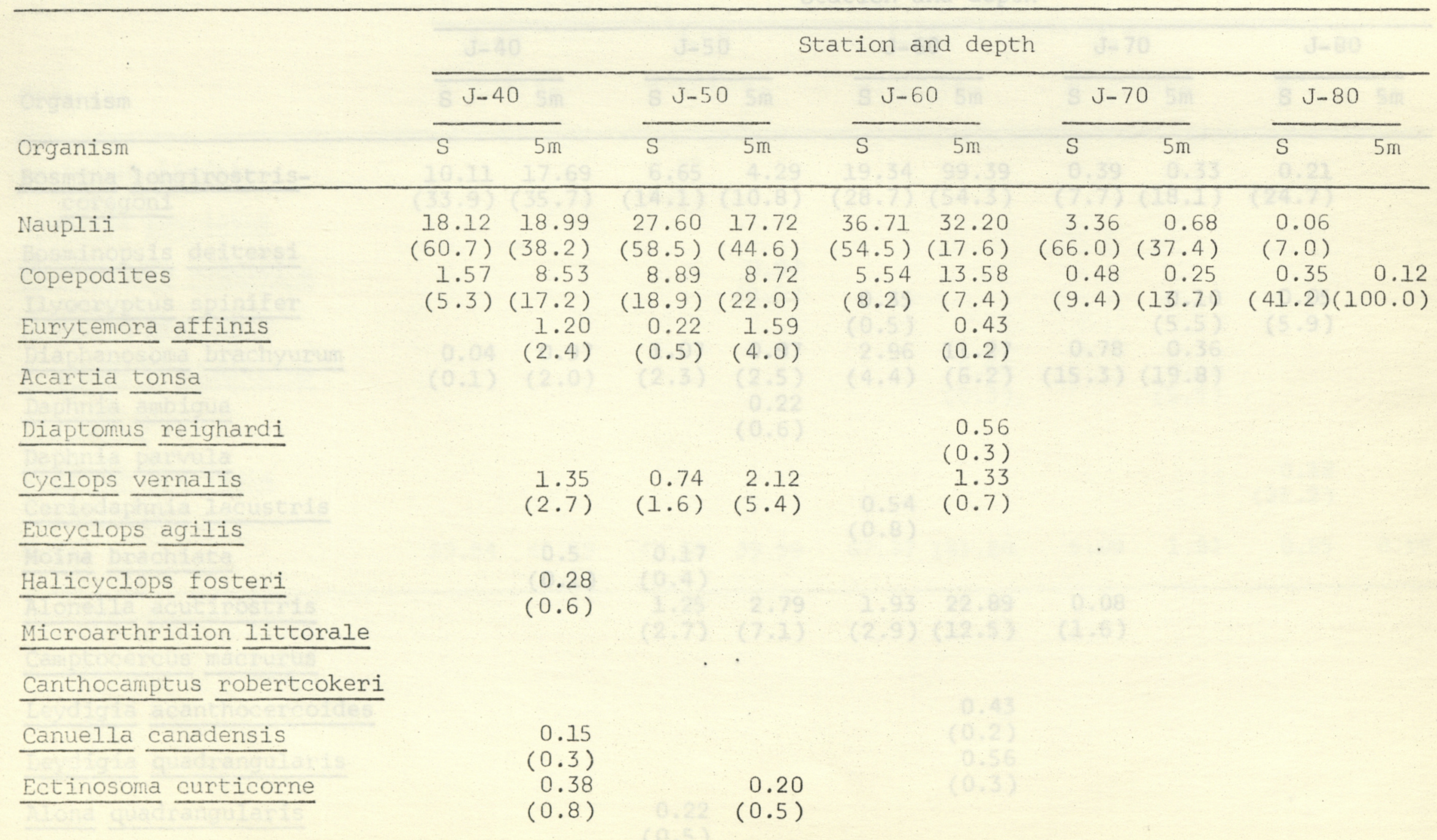


Table A4. (Continued).

\begin{tabular}{|c|c|c|c|c|c|c|c|c|c|c|}
\hline \multirow[b]{3}{*}{ Organism } & \multicolumn{10}{|c|}{ Station and depth } \\
\hline & \multicolumn{2}{|c|}{$J-40$} & \multicolumn{2}{|c|}{$\mathrm{J}-50$} & \multicolumn{2}{|c|}{$J-60$} & \multicolumn{2}{|c|}{$\mathrm{J}-70$} & \multicolumn{2}{|c|}{$\mathrm{J}-80$} \\
\hline & $S$ & $5 m$ & $\mathrm{~S}$ & $5 m$ & $S$ & $5 \mathrm{~m}$ & $S$ & $5 \mathrm{~m}$ & S & $5 \mathrm{~m}$ \\
\hline$\frac{\text { Bosmina }}{\text { coregoni }}$ & $\begin{array}{l}10.11 \\
(33.9)\end{array}$ & $\begin{array}{r}17.69 \\
(35.7)\end{array}$ & $\begin{array}{r}6.65 \\
(14.1)\end{array}$ & $\begin{array}{r}4.29 \\
(10.8)\end{array}$ & $\begin{array}{l}19.34 \\
(28.7)\end{array}$ & $\begin{array}{r}99.39 \\
(54.3)\end{array}$ & $\begin{array}{r}0.39 \\
(7.7)\end{array}$ & $\begin{array}{r}0.33 \\
(18.1)\end{array}$ & $\begin{array}{r}0.21 \\
(24.7)\end{array}$ & \\
\hline \multicolumn{11}{|l|}{ Bosminopsis deitersi } \\
\hline Ilyocryptus spinifer & & & & & $\begin{array}{r}0.35 \\
(0.5)\end{array}$ & & & $\begin{array}{r}0.10 \\
(5.5)\end{array}$ & $\begin{array}{r}0.05 \\
(5.9)\end{array}$ & \\
\hline Diaphanosoma brachyurum & $\begin{array}{r}0.04 \\
(0.1)\end{array}$ & $\begin{array}{r}0.97 \\
(2.0)\end{array}$ & $\begin{array}{r}1.07 \\
(2.3)\end{array}$ & $\begin{array}{r}0.97 \\
(2.5)\end{array}$ & $\begin{array}{r}2.96 \\
(4.4)\end{array}$ & $\begin{array}{l}1.1 .27 \\
(6.2)\end{array}$ & $\begin{array}{r}0.78 \\
(15.3)\end{array}$ & $\begin{array}{r}0.36 \\
(19.8)\end{array}$ & & \\
\hline Daphnia ambigua & & & & $\begin{array}{r}0.22 \\
(0.6)\end{array}$ & & & & & & \\
\hline Daphnia parvula & & & & & & & & & & \\
\hline Ceriodaphnia lacustris & & & & & $\begin{array}{r}0.54 \\
(0.8)\end{array}$ & & & & $(2+2)$ & \\
\hline Moina brachiata & & $\begin{array}{c}0.5 \\
(0.1)\end{array}$ & $\begin{array}{r}0.17 \\
(0.4)\end{array}$ & & $x+\frac{1}{2}$ & 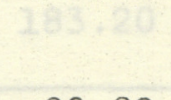 & $\cdot 9$ & & 0.65 & 20 \\
\hline Alonella acutirostris & & & $\begin{array}{l}1.25 \\
(2.7)\end{array}$ & $\begin{array}{r}2.79 \\
(7.1)\end{array}$ & $\begin{array}{l}1.93 \\
(2.9)\end{array}$ & $\begin{array}{r}22.89 \\
(12.5)\end{array}$ & $\begin{array}{r}0.08 \\
(1.6)\end{array}$ & & & \\
\hline Camptocercus macrurus & & & . & $\cdot$ & & & & & & \\
\hline $\begin{array}{l}\text { Leydigia acanthocercoides } \\
\text { Leydigia quadrangularis }\end{array}$ & & & & & & $\begin{array}{r}0.43 \\
(0.2) \\
0.56 \\
(0.3)\end{array}$ & & & & \\
\hline Alona quadrangularis & & & $\begin{array}{r}0.22 \\
(0.5)\end{array}$ & & & & & & & \\
\hline Alona guttata & & & & & & & & & - & \\
\hline
\end{tabular}


Table A4. (Continued)

Station and depth

$\frac{\mathrm{J}-40}{\mathrm{~S}-40 \mathrm{~m}} \quad \frac{\mathrm{J}-50}{\mathrm{~S}} \frac{\mathrm{J}-60}{\mathrm{~S}} \frac{\mathrm{J}-70}{\mathrm{~S}} \quad \frac{\mathrm{J}-80}{\mathrm{~S}}$

Leptodora kindtii

Gammarus fasciatus

Physocypria exquisita

Neomysis americana

Procladius adumbratus

Chaoborus sp.

$$
\begin{array}{r}
0.22 \\
(0.5)
\end{array}
$$

Pristina breviseta

$$
\begin{array}{rr}
0.56 & 0.10 \\
(0.3) & (5.5)
\end{array}
$$

0.97

$(2.5)$

0.18
$(21.2)$

Total

$29.84 \quad 49.59$

47.03

39.59

$67.37 \quad 183.20$

5.09

1.82

$0.85 \quad 0.12$ 
Table A5. Zooplankton standing crops as number per liter. Percentage of total number of organisms per liter in parentheses. Date: 18-21 August 1969. S, surface; 5m, 5 meters

Station and depth

Organism

$\frac{\mathrm{J}-40}{S \quad \frac{J-50}{S} \quad \frac{J-60}{S}}$

Nauplii

Copepodites

Eurytemora affinis

Acartia tonsa

Diaptomus reighardi

Cyclops vernalis

Eucyclops agilis

Halicyclops fosteri

Microarthridion littorale

Canthocamptus robertcokeri

Canuella canadensis

Ectinosoma curticorne

$\begin{array}{rrrrrrrrrr}10.19 & 1.72 & 34.91 & 18.47 & 16.19 & 20.37 & 14.13 & 14.87 & 0.04 & 0.08 \\ (78.3) & (19.7) & (70.5) & (46.2) & (33.0) & (17.0) & (30.2) & (16.6) & (57.1) & (53.3) \\ 1.71 & 2.92 & 8.01 & 12.74 & 1.79 & 13.65 & 4.17 & 8.37 & 0.03 & 0.07 \\ (13.1) & (33.5) & (16.2) & (32.0) & (3.6) & (11.3) & (8.9) & (9.4) & (42.9) & (46.7) \\ & 2.02 & 0.36 & 1.70 & & 2.83 & 0.17 & 1.13 & & \\ & (23.2) & (0.7) & (4.3) & & (2.3) & (0.4) & (1.3) & & \end{array}$

$\begin{array}{rrrrrr}1.26 & 0.23 & 1.49 & 0.17 & 5.70 & 3.89 \\ (14.4) & (0.5) & (3.7) & (0.3) & (4.7) & (4.4)\end{array}$

0.06

$(0.17)$

0.03

$(0.3)$ 
Table A5. (Continued).

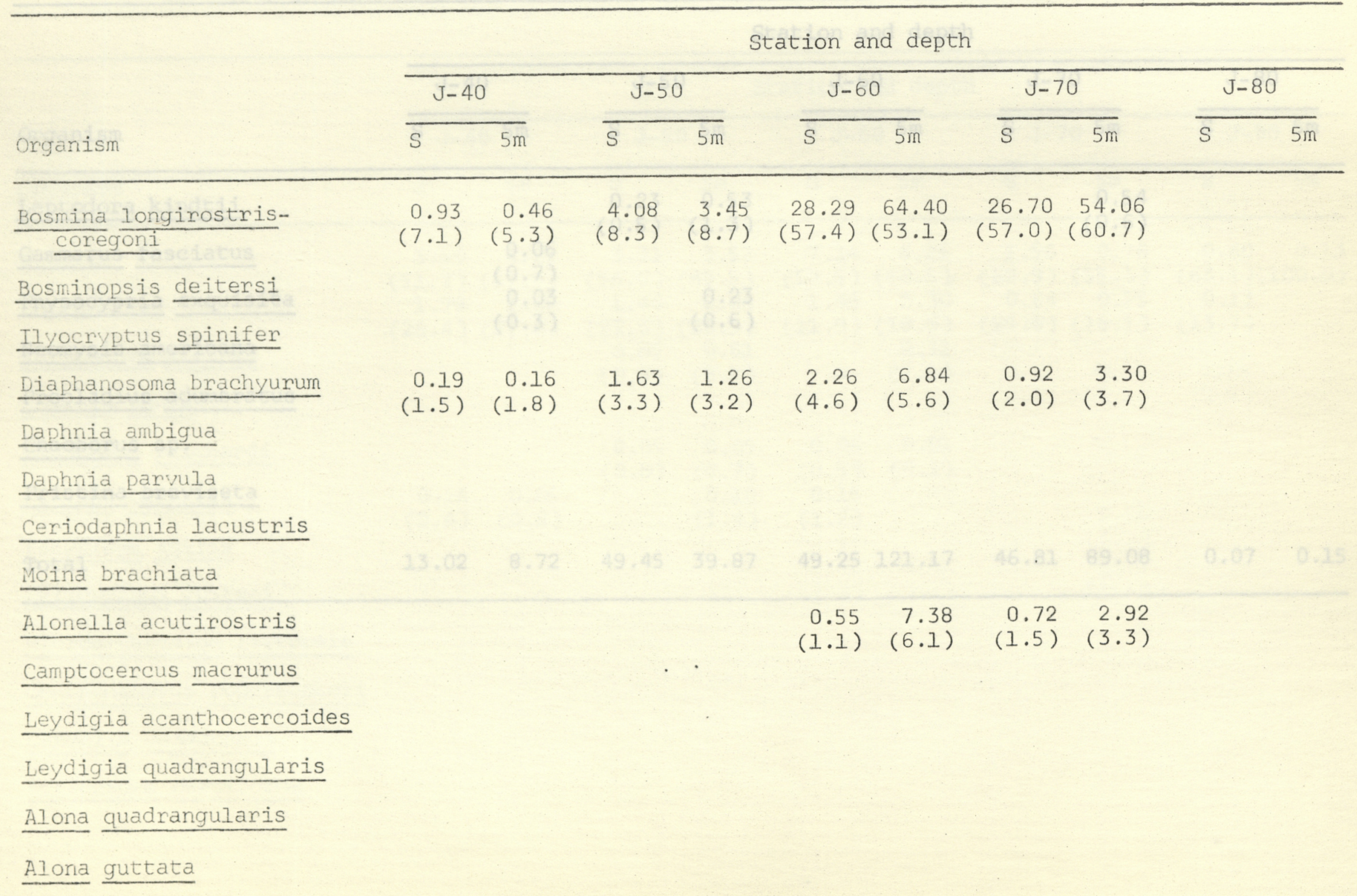


Table A5. (Continued).

Station and depth

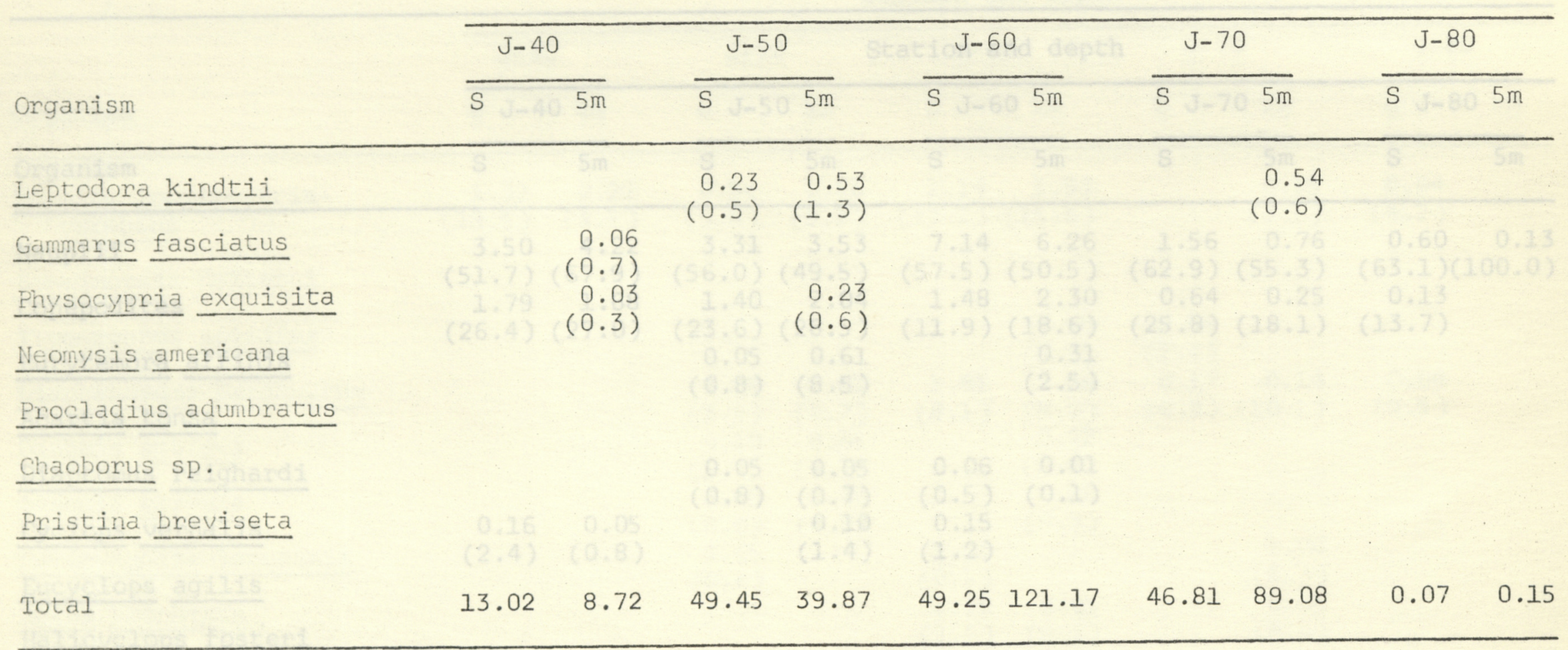


Table A6. Zooplankton standing crops as number per liter. Percentage of total number of organisms per liter in parentheses. Date: 29 August 1969. S, surface; 5m, 5 meters

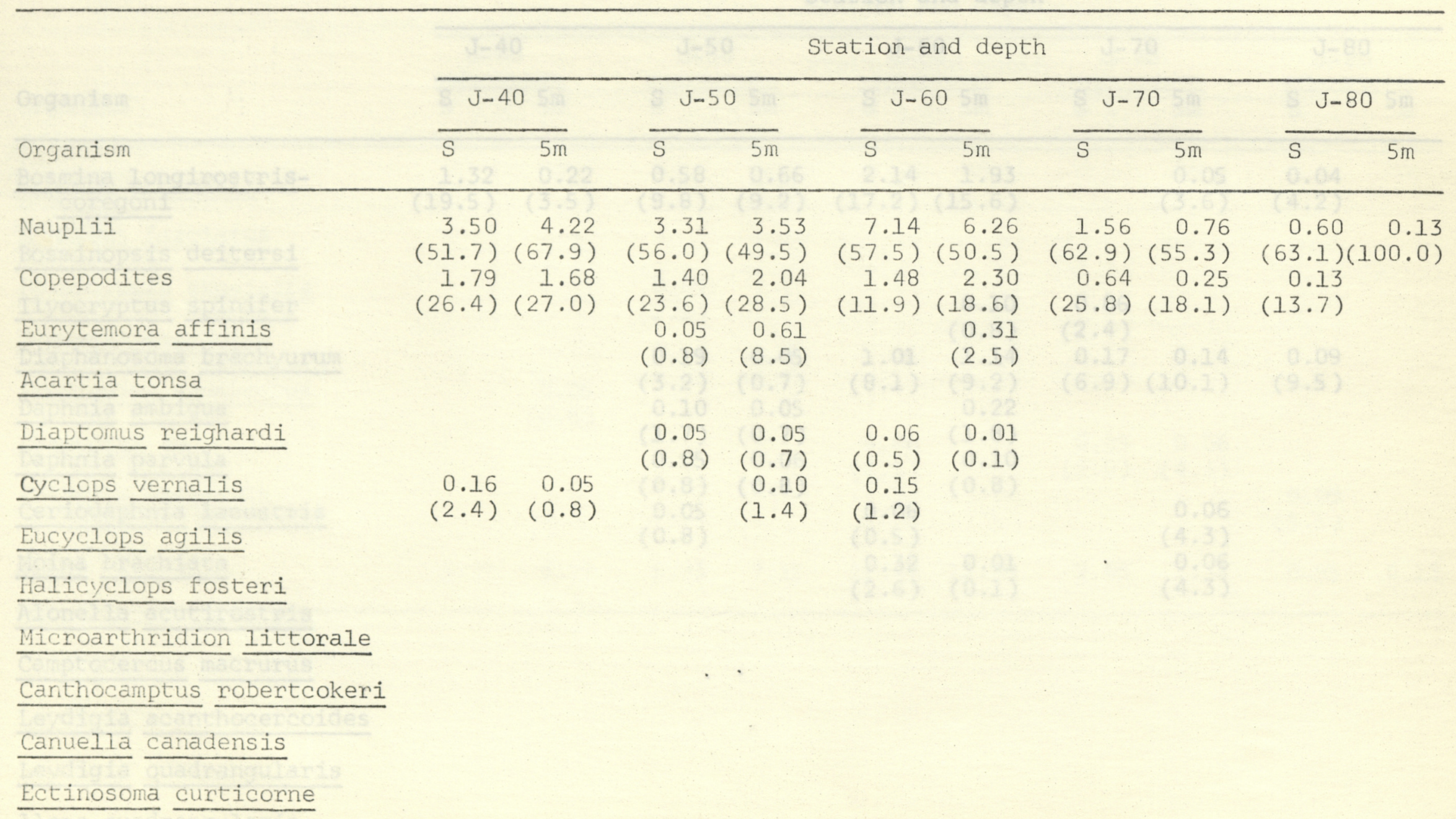


Table A6. (Continued).

Station and depth

Organism

$\frac{\mathrm{J}-40}{\mathrm{~S} 5 \mathrm{~m}} \frac{\mathrm{J}-50}{\mathrm{~S} 5 \mathrm{~m}} \quad \frac{\mathrm{J}-60}{\mathrm{~S} 5 \mathrm{~m}} \frac{\mathrm{J}-70}{\mathrm{~S} 5 \mathrm{~m}}$

$\frac{\text { Bosmina longirostris- }}{\text { coregoni }}$

$\begin{array}{rrrrrr}1.32 & 0.22 & 0.58 & 0.66 & 2.14 & 1.93 \\ (19.5) & (3.5) & (9.8) & (9.2) & (17.2) & (15.6)\end{array}$

$0.05 \quad 0.04$

$(19.5) \quad(3.5)$

(9.8)

$(17.2)(15.6)$

$(3.6) \quad(4.2)$

Bosminopsis deitersi

Ilyocryptus spinifer

Diaphanosoma brachyurum

Daphnia ambigua

Daphnia parvula

Ceriodaphnia lacustris

Moina brachiata

\begin{tabular}{rrrrrrr} 
& \multicolumn{7}{c}{0.10} & 0.06 & & \\
0.19 & 0.05 & 1.01 & $(0.8)$ & $(2.4)$ & & \\
$(3.14$ & 0.17 & 0.14 & 0.09 \\
0.10 & $(0.7)$ & $(8.1)$ & $(9.2)$ & $(6.9)$ & $(10.1)$ & $(9.5)$ \\
$(1.7)$ & $(0.05$ & & 0.22 & & & \\
0.05 & 0.06 & & $(1.8)$ & & & \\
$(0.8)$ & $(0.8)$ & & 0.10 & & & \\
0.05 & & 0.06 & & & & \\
$(0.8)$ & & $(0.5)$ & & 0.06 & \\
& & 0.32 & 0.01 & & $0.3)$ & \\
& & $(2.6)$ & $(0.1)$ & & $(4.3)$ &
\end{tabular}

Alonella acutirostris

Camptocercus macrurus

Leydigia acanthocercoides

Leydigia quadrangularis

Alona quadrangularis

Aiona guttata 
Table A6. (Continued).

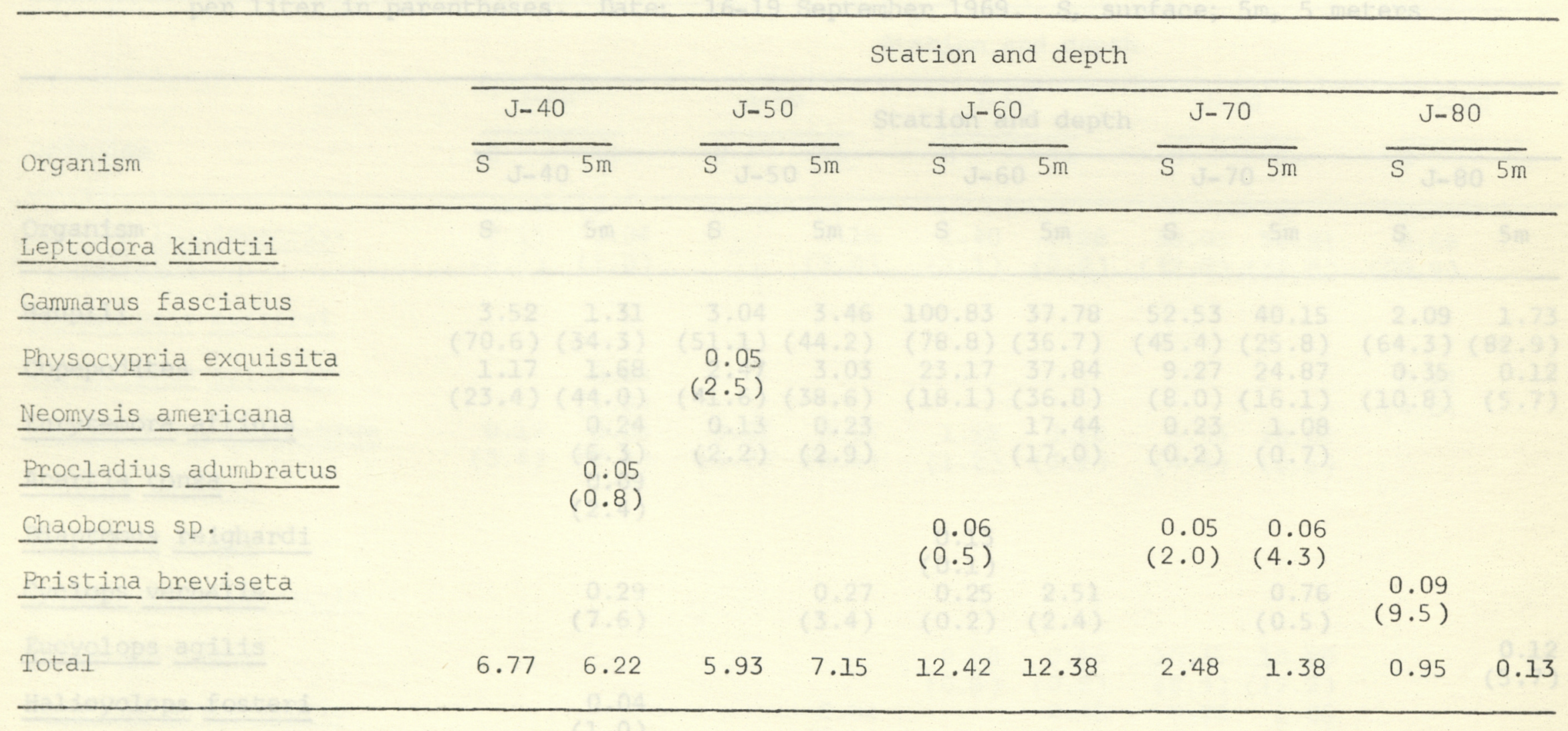


Table A7. Zooplankton standing crops as number per liter. Percentage of total number of organisms per liter in parentheses. Date: 16-19 September 1969. S, surface; $5 \mathrm{~m}, 5$ meters

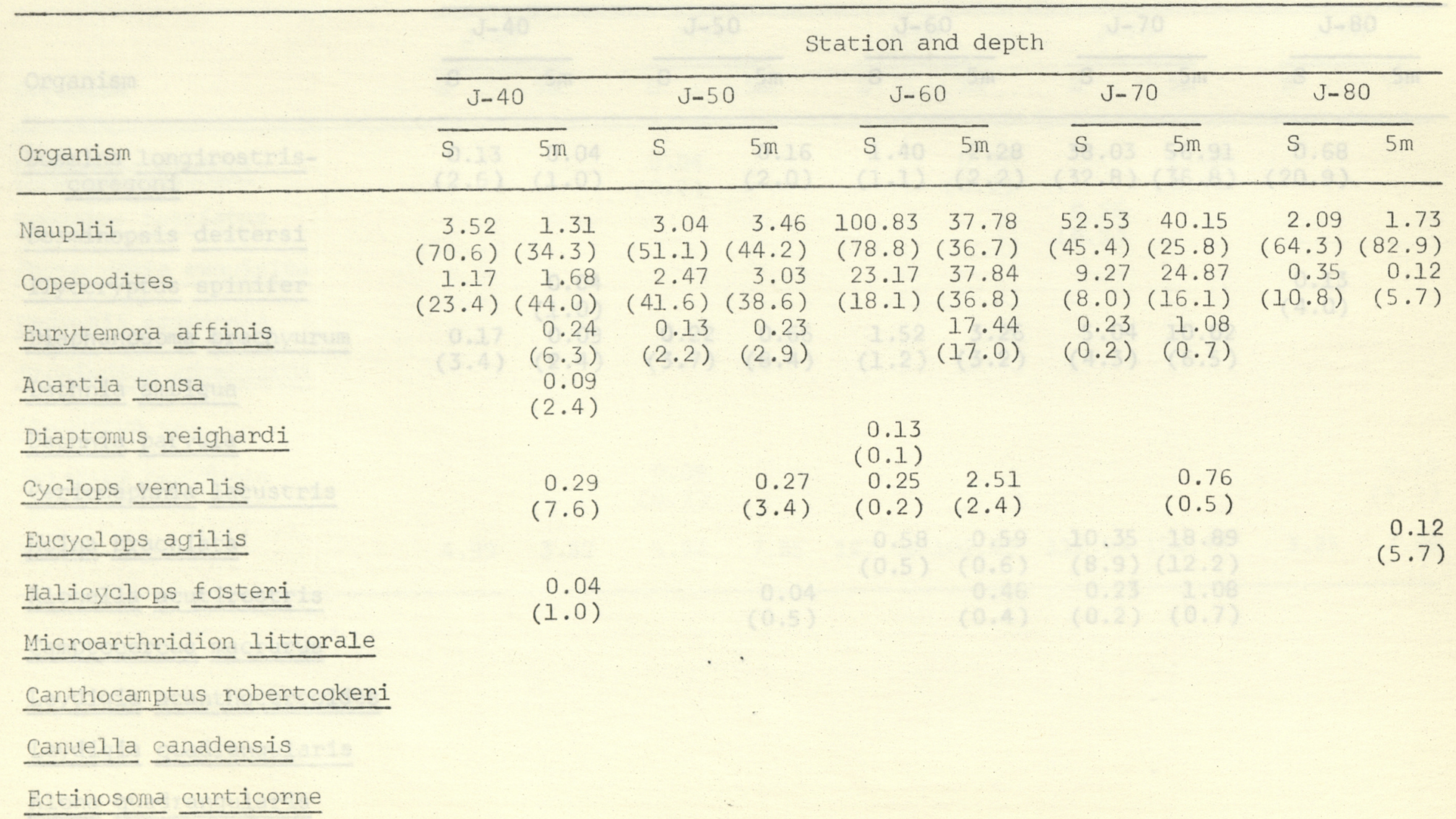


Table A7. (Continued).

Station and depth

Organism

$\frac{\mathrm{J}-40}{\mathrm{~S} 5 \mathrm{~m}} \frac{\mathrm{J}-50}{\mathrm{~S} 5 \mathrm{~m}} \quad \frac{\mathrm{J}-60}{\mathrm{~S} 5 \mathrm{~m}} \quad \frac{\mathrm{J}-70}{\mathrm{~S} \quad 5 \mathrm{~m}}$

Bosmina longirostriscoregoni

0.130 .04

$(2.6) \quad(1.0)$

0.16

1.40

2.28

$38.03 \quad 56.91$

0.68

Bosminopsis deitersi

Ilyocryptus spinifer

Diaphanosoma brachyurum

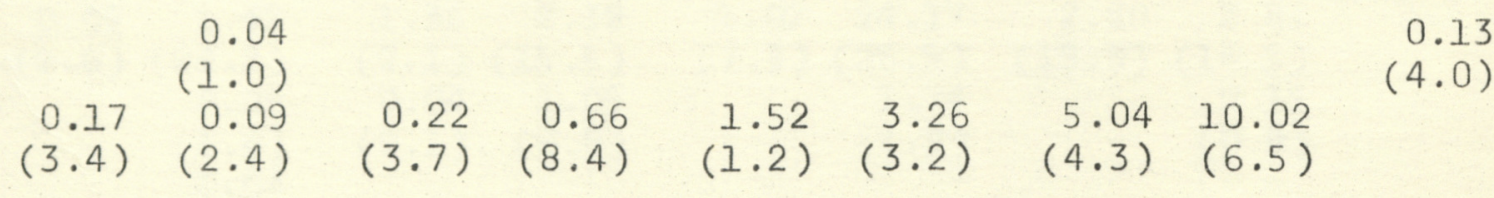

Daphnia ambigua

Daphnia parvula

Ceriodaphnia lacustris

Moina brachiata

Alonella acutirostris

Camptocercus macrurus

$\begin{array}{rrrrr} & 0.58 & 0.59 & 10.35 & 18.89 \\ 0.04 & (0.5) & (0.6) & (8.9) & (12.2) \\ (0.5) & & 0.46 & 0.23 & 1.08 \\ & & (0.4) & (0.2) & (0.7)\end{array}$

Leydigia acanthocercoides

Leydigia quadrangularis

Alona quadrangularis

Alona guttata 
Table A7. (Continued).

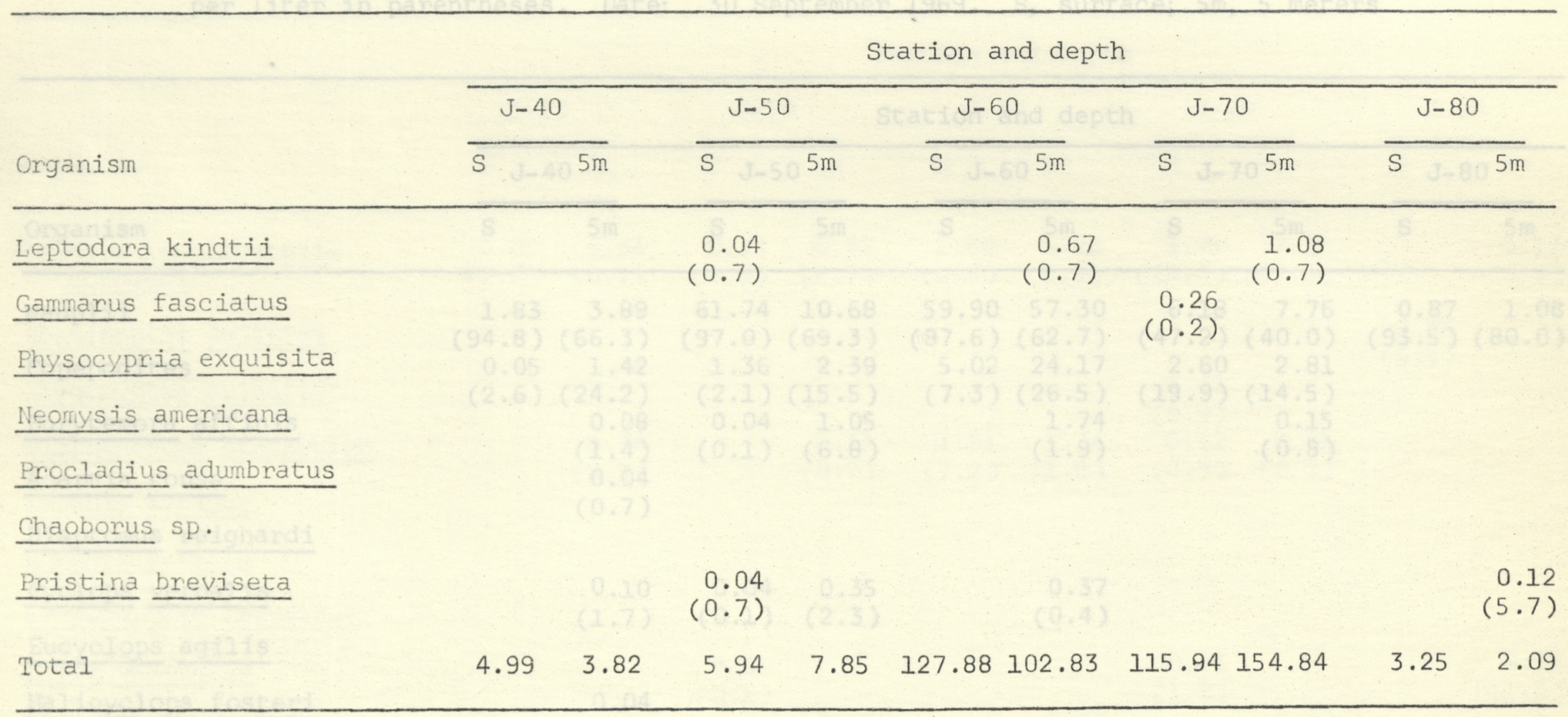


Table A8. Zooplankton standing crops as number pér liter. Percentage of total number of organisms per liter in parentheses. Date: 30 september 1969. S, surface; $5 \mathrm{~m}$, 5 meters

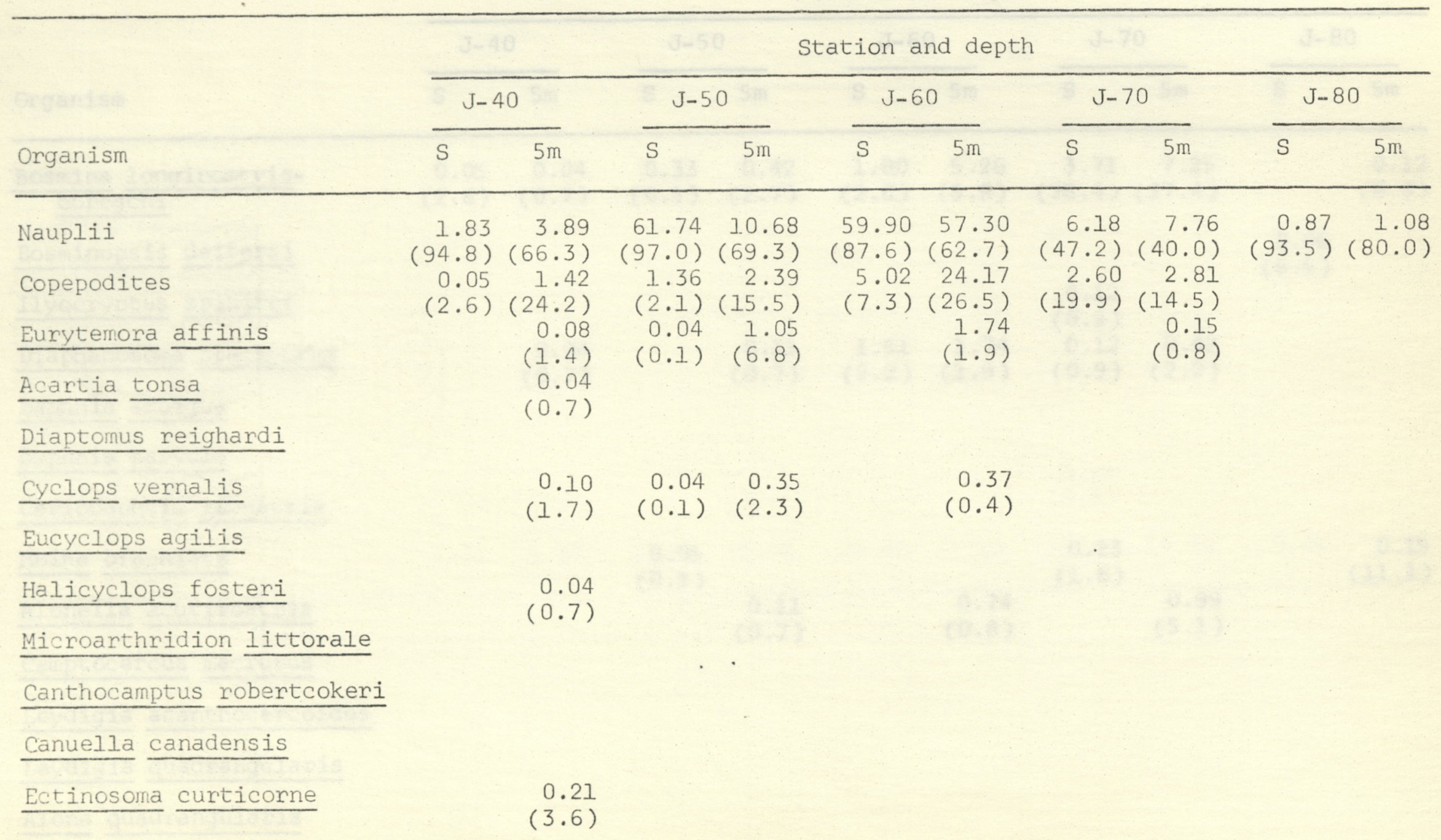


Table A8. (Continued).

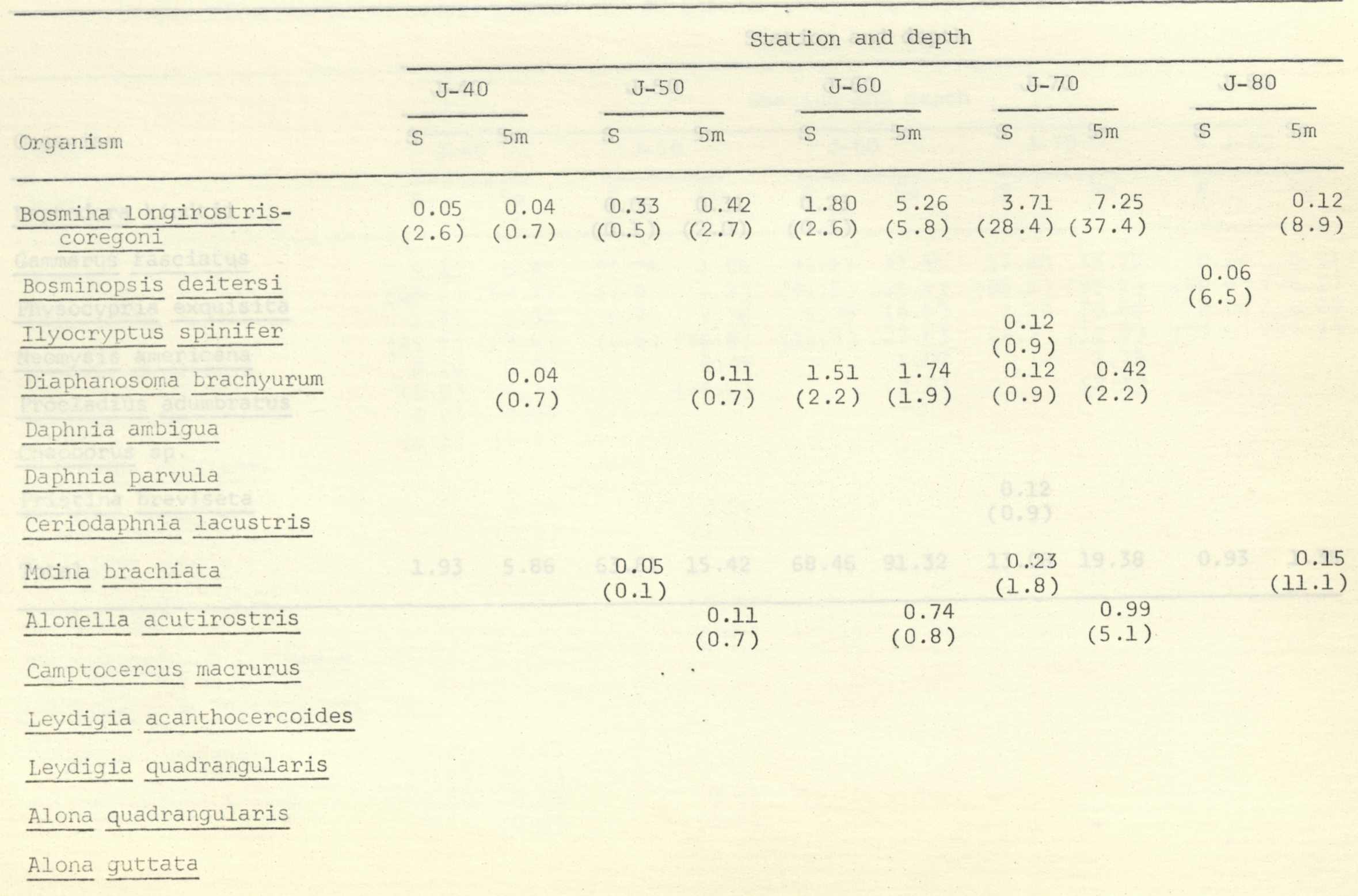


Table A8. (continued).

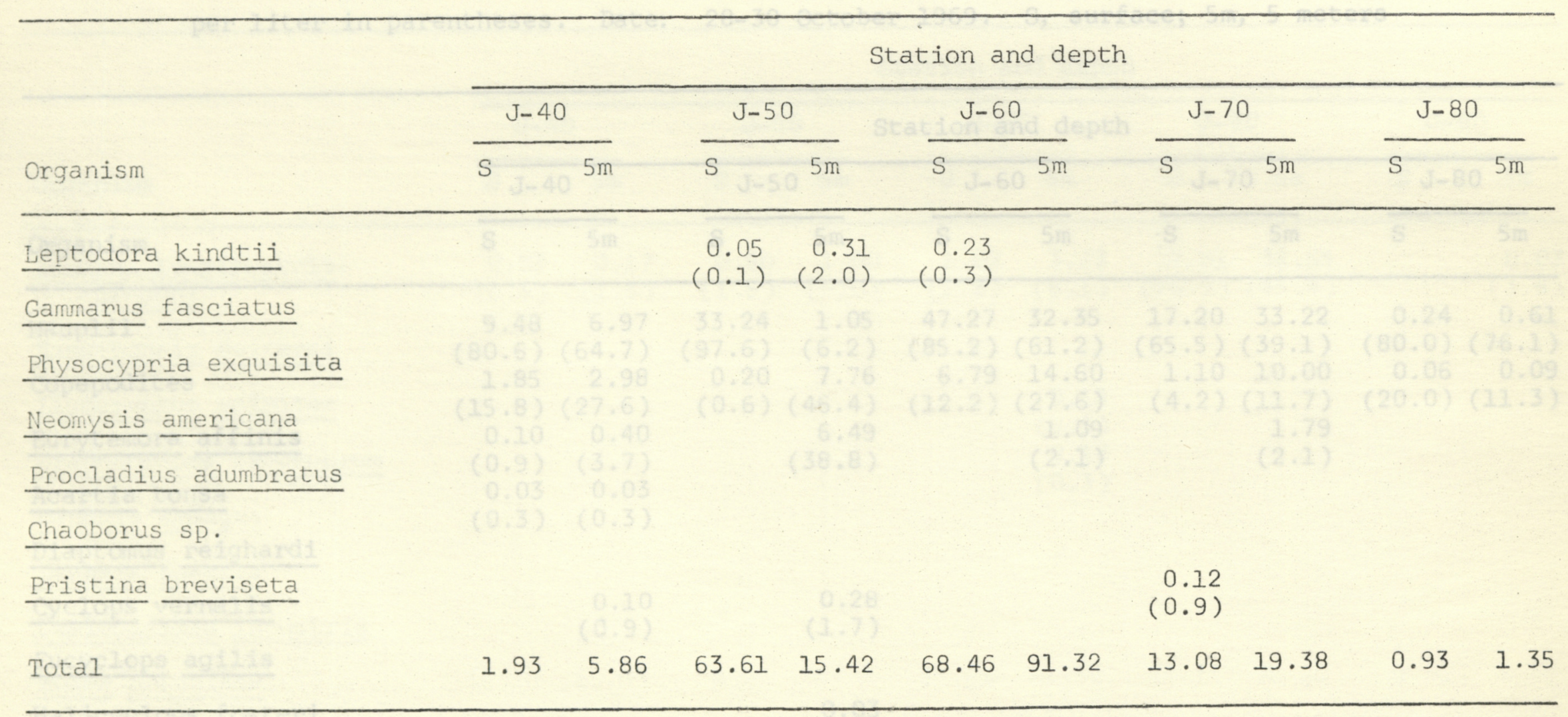


Table A9. Zooplankton standing crops as number per liter. Percentage of total number of organisms per liter in parentheses. Date: 28-30 October 1969. S, surface; 5m, 5 meters

\begin{tabular}{|c|c|c|c|c|c|c|c|c|c|c|}
\hline \multirow[b]{3}{*}{ Organism } & \multicolumn{2}{|c|}{$x-1+40$} & \multicolumn{2}{|c|}{1550} & \multicolumn{2}{|c|}{ Station and depth } & \multicolumn{2}{|c|}{$y=70$} & \multicolumn{2}{|c|}{$3-80$} \\
\hline & \multicolumn{2}{|c|}{$\mathrm{J}-40$} & \multicolumn{2}{|c|}{$J-50$} & \multicolumn{2}{|c|}{$J-60$} & \multicolumn{2}{|c|}{$\mathrm{J}-70$} & \multicolumn{2}{|c|}{$\mathrm{J}-80$} \\
\hline & $\mathrm{S} \quad 3$ & $5 \mathrm{~m}$ & S & $5 \mathrm{~m}$ & S & $5 \mathrm{~m}$ & $S$ & $5 \mathrm{~m}$ & $\bar{S}$ & $5 \mathrm{~m}$ \\
\hline $\begin{array}{l}\text { Nauplii } \\
\text { Copepodites } \\
\text { Eurytemora affinis } \\
\text { Acartia tonsa } \\
\text { Diaptomus reighardi }\end{array}$ & $\begin{array}{r}9.48 \\
(80.6) \\
1.85 \\
(15.8) \\
0.10 \\
(0.9) \\
0.03 \\
(0.3)\end{array}$ & $\begin{array}{r}6.97 \\
(64.7) \\
2.98 \\
(27.6) \\
0.40 \\
(3.7) \\
0.03 \\
(0.3)\end{array}$ & $\begin{array}{r}33.24 \\
(97.6) \\
0.20 \\
(0.6)\end{array}$ & $\begin{array}{r}1.05 \\
(6.2) \\
7.76 \\
(46.4) \\
6.49 \\
(38.8)\end{array}$ & $\begin{array}{r}47.27 \\
(85.2) \\
6.79 \\
(12.2)\end{array}$ & $\begin{array}{r}32.35 \\
(61.2) \\
14.60 \\
(27.6) \\
1.09 \\
(2.1)\end{array}$ & $\begin{array}{r}17.20 \\
(65.5) \\
1.10 \\
(4.2)\end{array}$ & $\begin{array}{r}33.22 \\
(39.1) \\
10.00 \\
(11.7) \\
1.79 \\
(2.1)\end{array}$ & $\begin{array}{r}0.24 \\
(80.0) \\
0.06 \\
(20.0)\end{array}$ & $\begin{array}{r}0.61 \\
(76.1) \\
0.09 \\
(11.3)\end{array}$ \\
\hline $\begin{array}{l}\text { Cyclops vernalis } \\
\text { Eucyclops agilis }\end{array}$ & & $\begin{array}{r}0.10 \\
(0.9)\end{array}$ & & $\begin{array}{r}0.28 \\
(1.7)\end{array}$ & & & . & & & \\
\hline $\begin{array}{l}\text { Halicyclops fosteri } \\
\text { Microarthridion littorale }\end{array}$ & & & & $\begin{array}{r}0.03 \\
(0.2)\end{array}$ & & $\left(\frac{3 \times 09}{(2 \times 2)}\right.$ & & & & \\
\hline Canthocamptus robertcokeri & & & & & & & & & & \\
\hline $\begin{array}{l}\text { Canuella canadensis } \\
\text { Ectinosoma curticorne }\end{array}$ & $\begin{array}{r}0.21 \\
(1.8) \\
0.04 \\
(0.3)\end{array}$ & $\begin{array}{r}0.03 \\
(0.3) \\
0.10 \\
(0.9)\end{array}$ & & $\begin{array}{r}0.03 \\
(0.2)\end{array}$ & & & & & & \\
\hline
\end{tabular}


Table A9. (Continued).

Station and depth

\begin{tabular}{|c|c|c|c|c|c|c|c|c|c|c|}
\hline & & & & & & & & & & \\
\hline & $\mathrm{J}-4$ & & $J-5$ & & $J-6$ & & $\mathrm{~J}-7$ & & & \\
\hline Organism & $\bar{S}$ & $\overline{5 m}$ & $\bar{s}$ & $5 m$ & $s$ & $5 \mathrm{~m}$ & $\bar{S}$ & $\overline{5 m}$ & $\bar{s}$ & $5 \mathrm{~m}$ \\
\hline$\frac{\text { Bosmina }}{\text { coregoni }}$ & $\begin{array}{r}0.03 \\
(0.3)\end{array}$ & $\begin{array}{r}0.17 \\
(1.6)\end{array}$ & $\begin{array}{r}0.60 \\
(1.8)\end{array}$ & $\begin{array}{r}1.00 \\
(6.0)\end{array}$ & $\begin{array}{r}1.02 \\
(1.8)\end{array}$ & $\begin{array}{r}3.23 \\
(6.1)\end{array}$ & $\begin{array}{r}7.01 \\
(26.7)\end{array}$ & $\begin{array}{l}38.65 \\
(45.4)\end{array}$ & & $\begin{array}{l}0.0 \\
(3.8\end{array}$ \\
\hline
\end{tabular}

Bosminopsis deitersi

Ilyocryptus spinifer

Diaphanosoma brachyurum

Daphnia ambigua

Daphnia parvula

Ceriodaphnia lacustris

Moina brachiata

Alonella acutirostris

Camptocercus macrurus

0.18

$(0.3)$

$(0.3)$

Leydigia acanthocercoides

0.18

Leydigia quadrangularis

$\begin{array}{rrrrr}0.08 & 0.47 & 1.09 & 0.79 & 1.46 \\ (0.5) & (0.8) & (2.1) & (3.0) & (1.7)\end{array}$

Alona quadrangularis

Alona guttata 
Table A9. (Continued).

Station and depth

$\frac{\mathrm{J}-40}{\mathrm{~S} 5 \mathrm{~m}} \frac{\mathrm{J}-50}{\mathrm{~S}} \frac{\mathrm{J}-60}{\mathrm{~S}} \quad \frac{\mathrm{J}-70}{\mathrm{~S}} \quad \frac{\mathrm{J}}{5 \mathrm{~m}} \cdot \frac{\mathrm{J0}}{\mathrm{S}}$

Leptodora kindtii

0.17

Gammarus fasciatus

Physocypria exquisita

Neomysis americana

Procladius adumbratus

Chaoborus sp.

Pristina breviseta $(0.6)$

Pristina breviseta

(20.0707

$\begin{array}{llllllllllllll}\text { Total } & 11.74 & 10.78 & 34.04 & 16.72 & 55.55 & 52.90 & 26.27 & 85.12 & 0.30 & 0.80\end{array}$


Table A10. Zooplankton standing crops as number per liter. Percentage of total number of organisms per liter in parentheses. Date: 18-20 November 1969. S, surface; 5m, 5 meters

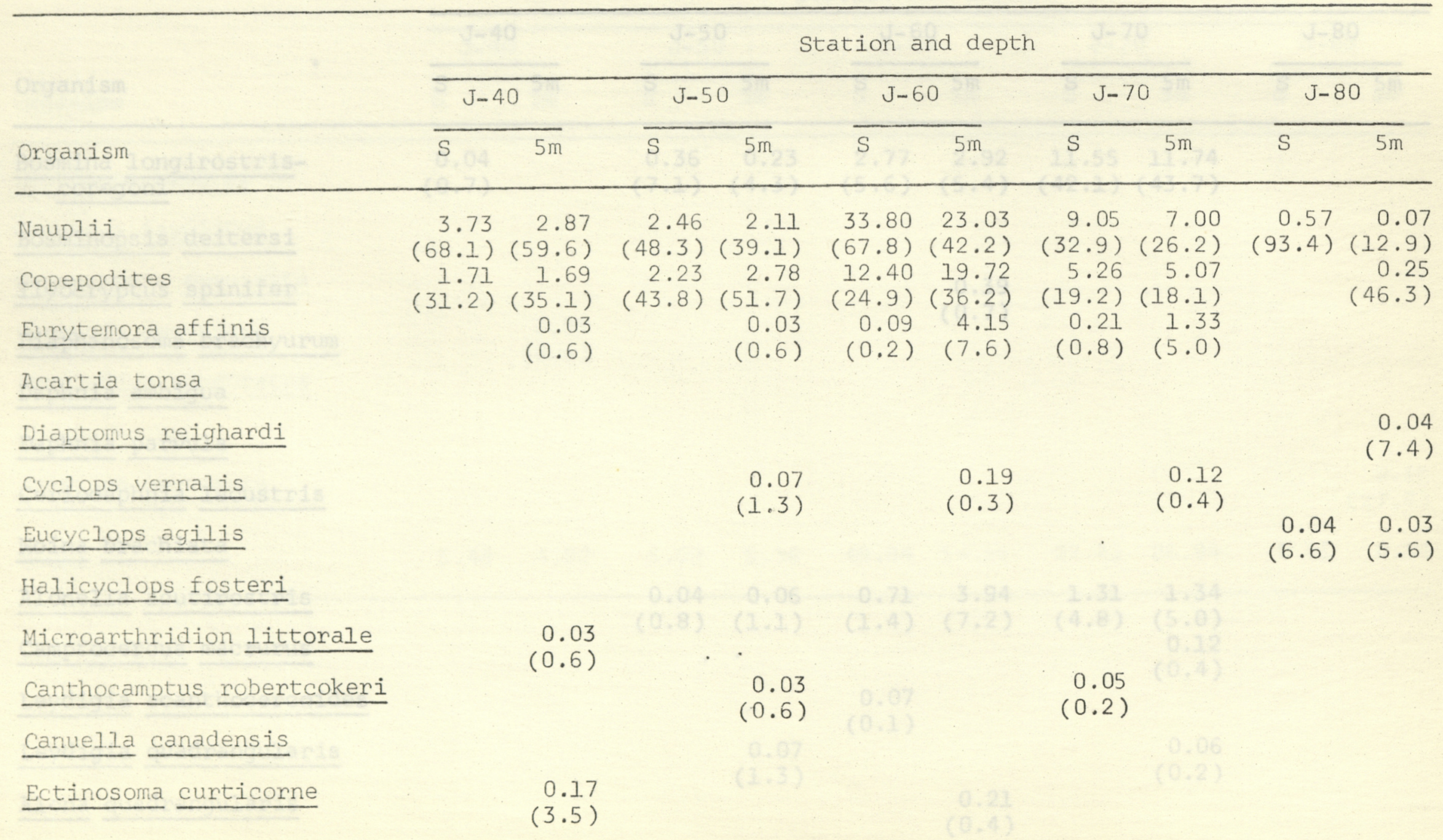


Table A10. (Continued).

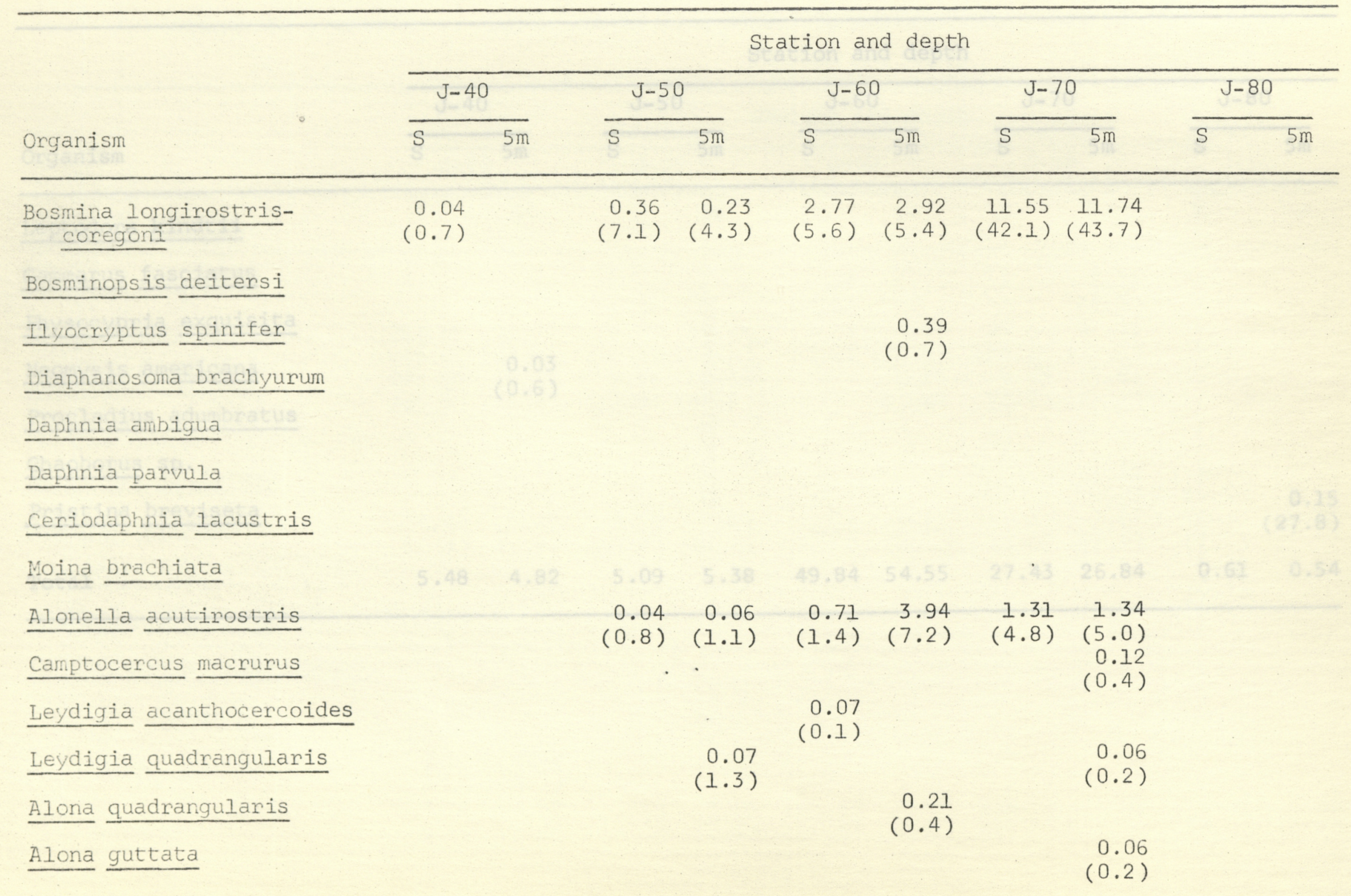


Table A10. (Continued).

\begin{tabular}{|c|c|c|c|c|c|c|c|c|c|c|}
\hline \multirow[b]{3}{*}{ Organism } & \multicolumn{10}{|c|}{ Station and depth } \\
\hline & \multicolumn{2}{|c|}{$\mathrm{J}-40$} & \multicolumn{2}{|c|}{$\mathrm{J}-50$} & \multicolumn{2}{|c|}{$J-60$} & \multicolumn{2}{|c|}{$\mathrm{J}-70$} & \multicolumn{2}{|c|}{$\mathrm{J}-80$} \\
\hline & $\bar{S}$ & $5 \mathrm{~m}$ & $\mathrm{~s}$ & $5 \mathrm{~m}$ & S & $5 \mathrm{~m}$ & $\mathrm{~S}$ & $5 \mathrm{~m}$ & $S$ & $\sqrt{5 m}$ \\
\hline \multicolumn{11}{|l|}{ Leptodora kindtii } \\
\hline \multicolumn{11}{|l|}{ Gamnarus fasciatus } \\
\hline \multicolumn{11}{|l|}{ Physocypria exquisita } \\
\hline Neomysis americana & & $\begin{array}{r}0.03 \\
(0.6)\end{array}$ & & & & & & & & \\
\hline \multicolumn{11}{|l|}{ Procladius adumbratus } \\
\hline \multicolumn{11}{|l|}{ Chaoborus sp. } \\
\hline Pristina breviseta & & & & & & & & & & $\begin{array}{r}0.15 \\
(27.8)\end{array}$ \\
\hline Total & 5.48 & 4.82 & 5.09 & 5.38 & 49.84 & 54.55 & 27.43 & 26.84 & 0.61 & 0.54 \\
\hline
\end{tabular}


Appendix B

Stomach contents 
Table BI. Stomach contents as number per stomach. Percentage of total number of organisms per stomach in parentheses. Date: 16-19 June 1969. S, surface; 5m, 5 meters

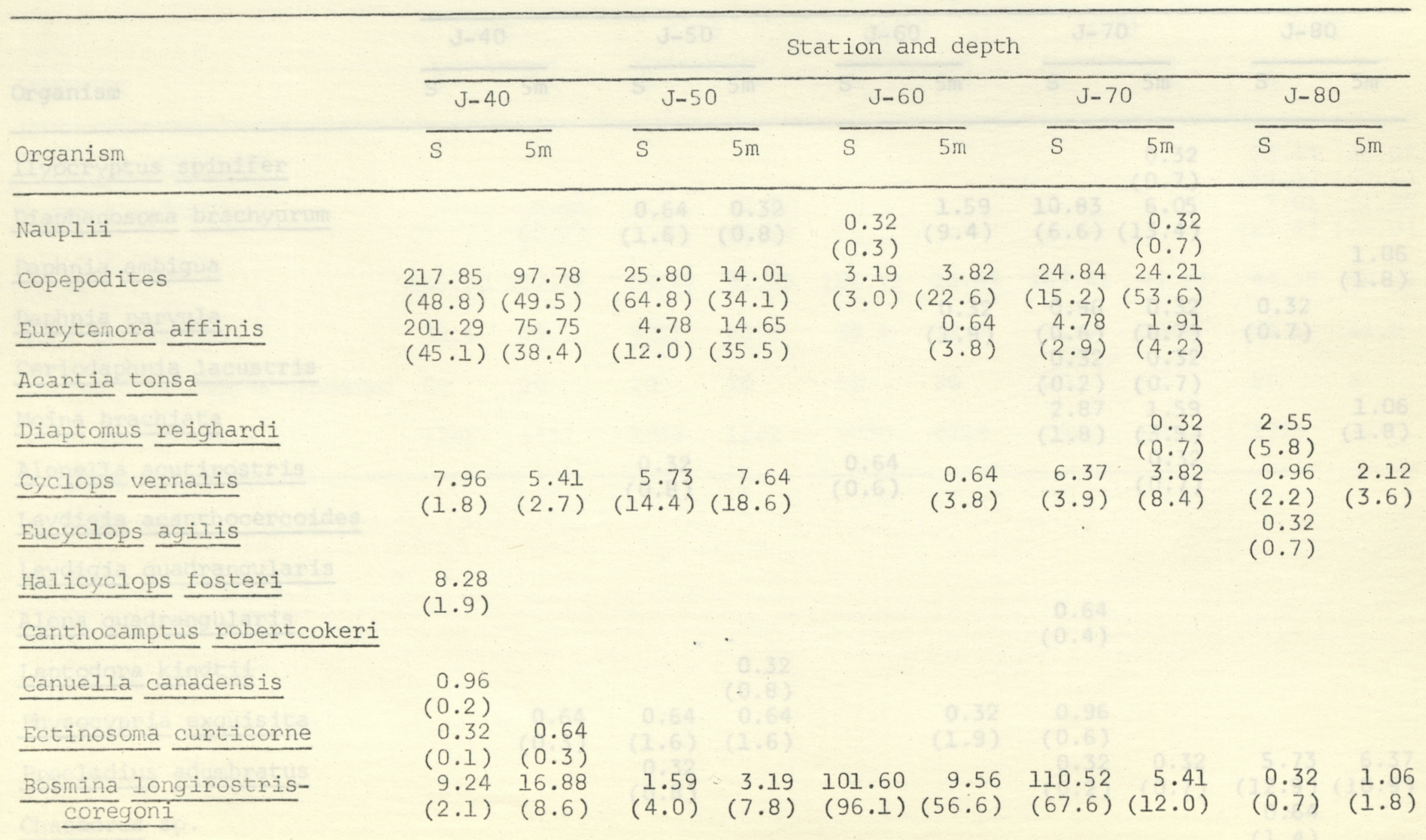


Table BI. (Continued).

Station and depth

Organism

$\frac{\mathrm{J}-40}{\mathrm{~S} 5 \mathrm{~m}} \frac{\mathrm{J}-50}{\mathrm{~S} 5 \mathrm{~m}} \frac{\mathrm{J}-60}{\mathrm{~S} 5 \mathrm{~m}} \frac{\mathrm{J}-70}{\mathrm{~S} \quad 5 \mathrm{~m}}$

Ilyocryptus spinifer

Diaphanosoma brachyurum

Daphria ambigua

Daphnia parvula

Ceriodaphnia lacustris

Moina brachiata

Alonella acutirostris

Leydigia acanthocercoides

$\begin{array}{rrrrr} & & 0.32 & \\ 1.59 & 10.83 & (0.7) & 6.05 & \\ (9.4) & (6.6) & (13.4) & & \\ & & & 1.06 \\ 0.32 & 0.96 & 0.32 & 0.32 & (1.8) \\ (1.9) & (0.6) & (0.7) & (0.7) & \\ & 0.32 & 0.32 & & \\ & (0.2) & (0.7) & & 1.06 \\ & 2.87 & 1.59 & & (1.8) \\ & (1.8) & (3.5) & & \\ & & 0.32 & & \end{array}$

Leydigia quadrangularis

Alona quadrangularis

Leptodora kindtii

Physocypria exquisita

Procladius adumbratus

$\begin{array}{lll}0.64 & 0.64 & 0.64\end{array}$

$(0.3) \quad(1.6) \quad(1.6)$

$\begin{array}{rr}0.64 & 0.32 \\ (1.6) & (0.8)\end{array}$

(n)

Chaoborus sp.

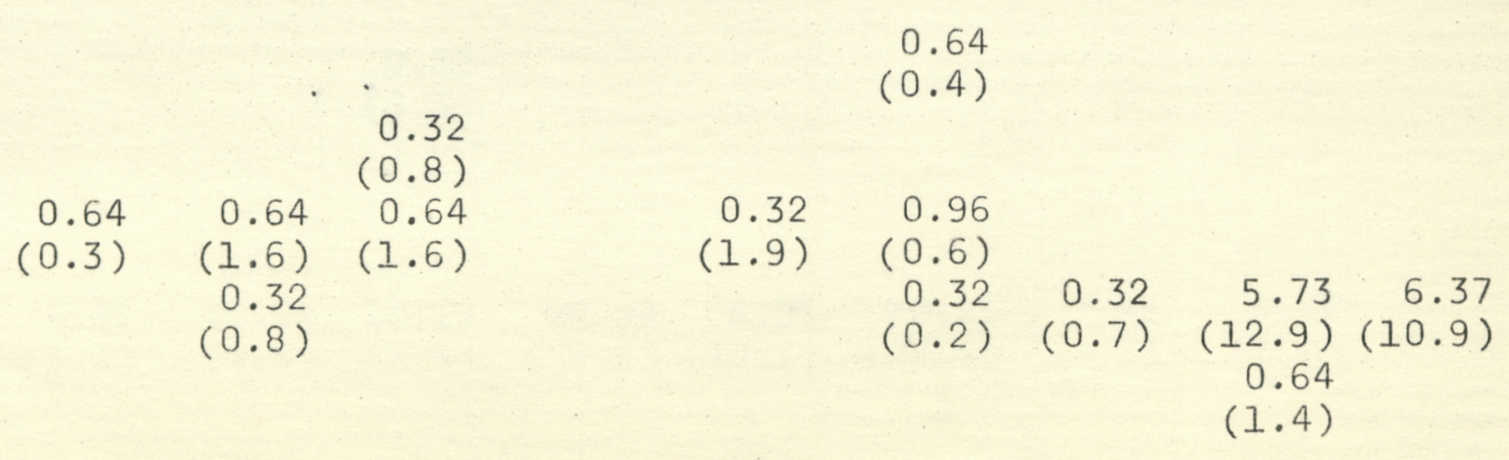


Table BI. (Continued).

\begin{tabular}{|c|c|c|c|c|c|c|c|c|c|c|}
\hline \multirow[b]{3}{*}{ Onganism } & \multicolumn{10}{|c|}{ Station and depth } \\
\hline & \multicolumn{2}{|c|}{$\mathrm{J}-40$} & \multicolumn{2}{|c|}{$\mathrm{J}-50$} & \multicolumn{2}{|c|}{$J-60$} & \multicolumn{2}{|c|}{$\mathrm{J}-70$} & \multicolumn{2}{|c|}{$\mathrm{J}-80$} \\
\hline & $\bar{s}$ & $5 \mathrm{~m}$ & $\mathrm{~S}$ & $5 m$ & $\bar{s}$ & $5 \mathrm{~m}$ & $\bar{S}$ & $\overline{5 m}$ & 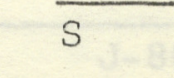 & $5 \mathrm{~m}$ \\
\hline Pristina breviseta & & & & & & $3=1$ & & & 26.44 & 35.04 \\
\hline Insecta (adult) & & $\begin{array}{r}0.32 \\
(0.2)\end{array}$ & & $\begin{array}{r}0.32 \\
(0.8)\end{array}$ & & & & & $\begin{array}{r}7.01 \\
(15.8)\end{array}$ & $\begin{array}{r}11.68 \\
(20.0)\end{array}$ \\
\hline Total & 445.90 & 197.42 & 39.82 & 41.09 & 105.75 & 16.89 & 163.41 & 45.23 & 44.29 & 58.39 \\
\hline Fork length (mm) & 38.6 & 39.1 & 40.1 & 40.8 & 38.1 & 38.7 & 35.7 & 30.0 & 43.5 & 41.0 \\
\hline Number of stomachs examined & 20 & 20 & 20 & 20 & 20 & 20 & 20 & 20 & 20 & 6 \\
\hline Time sample taken & 1246 & 1317 & 1032 & 1102 & 0730 & 0756 & 0825 & 0850 & 1215 & 1243 \\
\hline
\end{tabular}


Table B2. Stomach contents as number per stomach. Percentage of total number of organisms per stomach in parentheses. Date: 14-17 July 1969. S, surface; 5m, 5 meters

\begin{tabular}{|c|c|c|c|c|c|c|c|c|c|c|}
\hline \multirow[b]{3}{*}{ Organism } & \multicolumn{4}{|c|}{$3-40$} & \multicolumn{4}{|c|}{ Station and depth } & & \\
\hline & \multicolumn{2}{|c|}{$\mathrm{J}-40$} & \multicolumn{2}{|c|}{$\mathrm{J}-50$} & \multicolumn{2}{|c|}{$J-60$} & \multicolumn{2}{|c|}{$\mathrm{J}-70$} & \multicolumn{2}{|c|}{$\mathrm{J}-80$} \\
\hline & $\mathrm{S}$ & $5 \mathrm{~m}$ & $\bar{S}$ & $\overline{5 m}$ & $\bar{S}$ & $5 \mathrm{~m}$ & $\bar{S}$ & $\overline{5 m}$ & $\bar{S}$ & $5 \mathrm{~m}$ \\
\hline $\begin{array}{l}\text { Nauplii } \\
\text { Copepodites } \\
\frac{\text { Eurytemora affinis }}{\text { Acartia tonsa }} \\
\text { Diaptomus reighardi }\end{array}$ & $\begin{array}{r}27.07 \\
(50.8) \\
6.69 \\
(12.6)\end{array}$ & $\begin{array}{l}71.98 \\
(57.1) \\
37.90 \\
(30.1)\end{array}$ & $\begin{array}{r}1.59 \\
(0.8) \\
163.07 \\
(77.5) \\
1.59 \\
(0.8)\end{array}$ & $\begin{array}{r}0.64 \\
(0.5) \\
56.69 \\
(48.0) \\
8.28 \\
(7.0)\end{array}$ & $\begin{array}{r}0.32 \\
(0.7) \\
6.05 \\
(13.7)\end{array}$ & $\begin{array}{r}11 \cdot 15 \\
(55 \cdot 5)\end{array}$ & $\begin{array}{r}0.96 \\
(2.1) \\
19.75 \\
(42.7) \\
0.32 \\
(0.7)\end{array}$ & $\begin{array}{r}7.64 \\
(58.4) \\
(92)\end{array}$ & & $\begin{array}{r}0.64 \\
(6.9)\end{array}$ \\
\hline $\begin{array}{l}\text { Cyclops vernalis } \\
\frac{\text { Eucyclops }}{\text { agilis }} \\
\text { Halicyclops fosteri }\end{array}$ & & $\begin{array}{r}0.32 \\
(0.3)\end{array}$ & $\begin{array}{r}23.25 \\
(11.1)\end{array}$ & $\begin{array}{r}36.31 \\
(30.7)\end{array}$ & $\begin{array}{r}0.64 \\
(1.4)\end{array}$ & $\begin{array}{r}0.96 \\
(4.8)\end{array}$ & $\begin{array}{r}6.69 \\
(14.5) \\
\end{array}$ & $\begin{array}{r}0.64 \\
(4.9)\end{array}$ & $\begin{array}{r}0.64 \\
(10.0) \\
0.32 \\
(5.0)\end{array}$ & $\begin{array}{r}0.96 \\
(10.4)\end{array}$ \\
\hline $\begin{array}{l}\text { Canthocamptus robertcokeri } \\
\text { Canuella canadensis }\end{array}$ & & & . & $\begin{array}{r}0.32 \\
(0.3)\end{array}$ & & & & & & \\
\hline Ectinosoma curticonne & & & & & & & & & & \\
\hline$\frac{\text { Bosmina }}{\text { coregoni }}$ & $\begin{array}{r}12.42 \\
(23.4)\end{array}$ & $\begin{array}{r}6.37 \\
(5.1)\end{array}$ & $\begin{array}{l}15.29 \\
(7.3)\end{array}$ & $\frac{10.19}{(8.6)}$ & $\begin{array}{r}28.98 \\
(65.5)\end{array}$ & $\begin{array}{r}6.05 \\
(30.1)\end{array}$ & $\begin{array}{l}10.83 \\
(23.4)\end{array}$ & $\begin{array}{r}3.82 \\
(29.2)\end{array}$ & $\begin{array}{r}0.32 \\
(5.0)\end{array}$ & \\
\hline
\end{tabular}


Station and depth

Organism

$\frac{J-40}{S \quad 5 m} \quad \frac{J-50}{S \quad 5 m}$

$\frac{\mathrm{J}-60}{\mathrm{~S} 5 \mathrm{~m}}$

$\frac{J-70}{S} \frac{J-80}{S}$

Ilyocryptus spinifer

Diaphanosoma brachyurum

$\begin{array}{rrrrrrr}6.69 & 8.92 & 0.96 & 0.32 & 5.10 & 0.64 & 0.96 \\ (12.6) & (7.1) & (0.5) & (0.3) & (11.5) & (3.2) & (2.1)\end{array}$

1.27

(2.7)

0.96

Daphnia ambigua

Daphnia parvula

Ceriodaphnia lacustris

Moina brachiata

Alonella acutirostris

Leydigia acanthocercoides

Leydigia quadrangularis

Alona quadrangularis

Leptodora kindtii

Physocypria exquisita

Procladius adumbratus

Chaoborus SP.

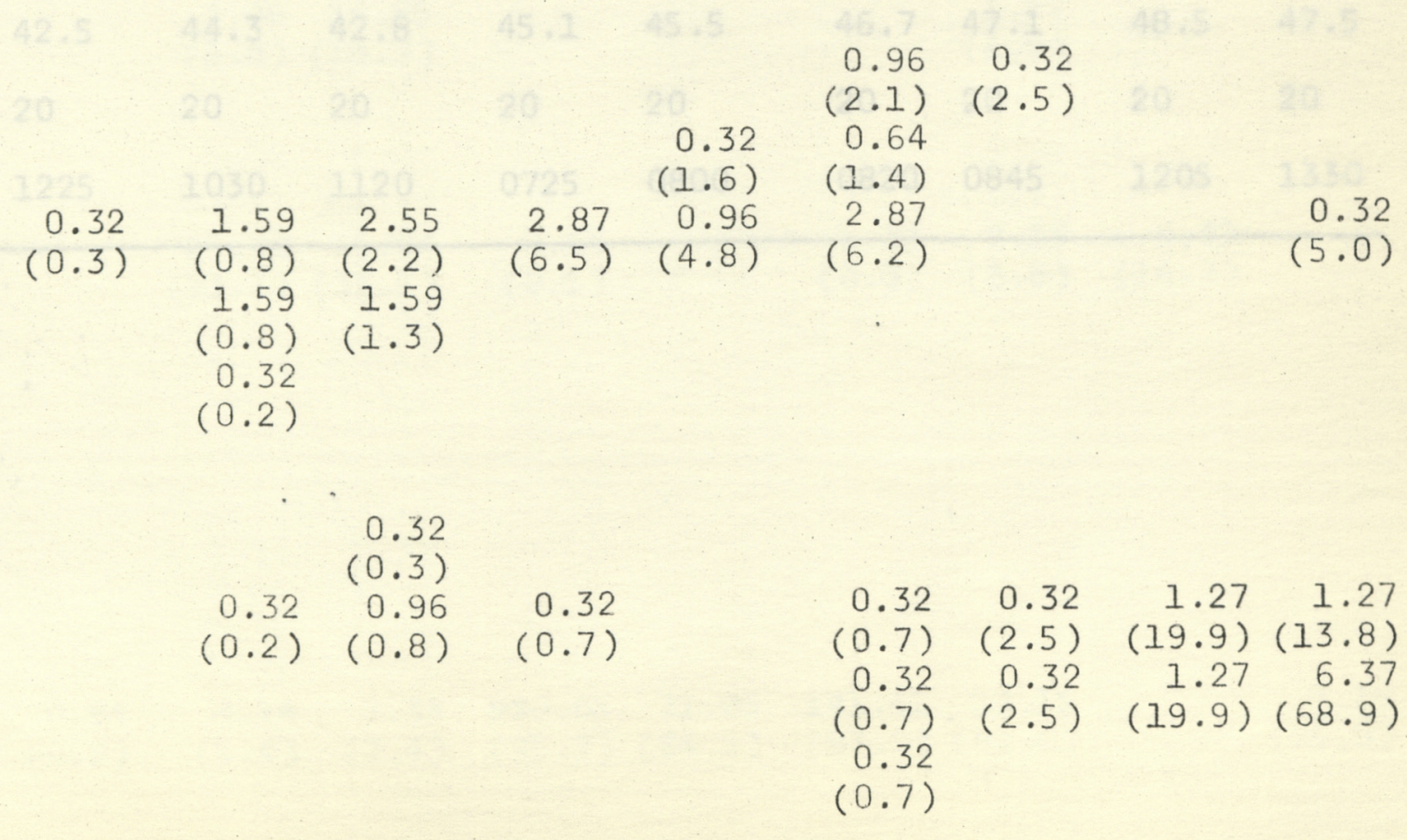


Table B2. (Continued).

\begin{tabular}{|c|c|c|c|c|c|c|c|c|c|c|}
\hline \multirow[b]{3}{*}{ Organism } & \multicolumn{10}{|c|}{ Station and depth } \\
\hline & \multicolumn{2}{|c|}{$J-40$} & \multicolumn{2}{|c|}{$\mathrm{J}-50$} & \multicolumn{2}{|c|}{$J-60$} & \multicolumn{2}{|c|}{$\mathrm{J}-70$} & \multicolumn{2}{|c|}{$J-80$} \\
\hline & $S$ & $5 \mathrm{~m}$ & $\mathrm{~S}$ & $5 m$ & S & $5 m$ & $\mathrm{~S}$ & $5 m$ & $\bar{S}$ & $5 m$ \\
\hline Pristina breviseta & & $x=$ & & & 8 & $5 x$ & & & 8 & an \\
\hline Insecta (adult) & & & & & & & & & $\begin{array}{r}1.27 \\
(19.9)\end{array}$ & \\
\hline Total & 53.19 & 125.81 & 209.57 & 118.17 & 44.28 & 20.08 & 46.21 & 13.06 & 6.37 & 9.24 \\
\hline Fork length (mm) & 39.6 & 42.5 & 44.3 & 42.8 & 45.1 & $45 \cdot 5$ & 46.7 & 47.1 & 48.5 & 47.5 \\
\hline Number of stomachs examined & 20 & 20 & 20 & 20 & 20 & 20 & 20 & 20 & 20 & 20 \\
\hline Time sample taken & 1130 & 1225 & 1030 & 1120 & 0725 & 0800 & 0820 & 0845 & 1205 & 1330 \\
\hline
\end{tabular}


Table B3. Stomach contents as number per stomach. Percentage of total number of organisms per stomach in parentheses. Date: 18-21 August 1969. S, surface; 5m, 5 meters

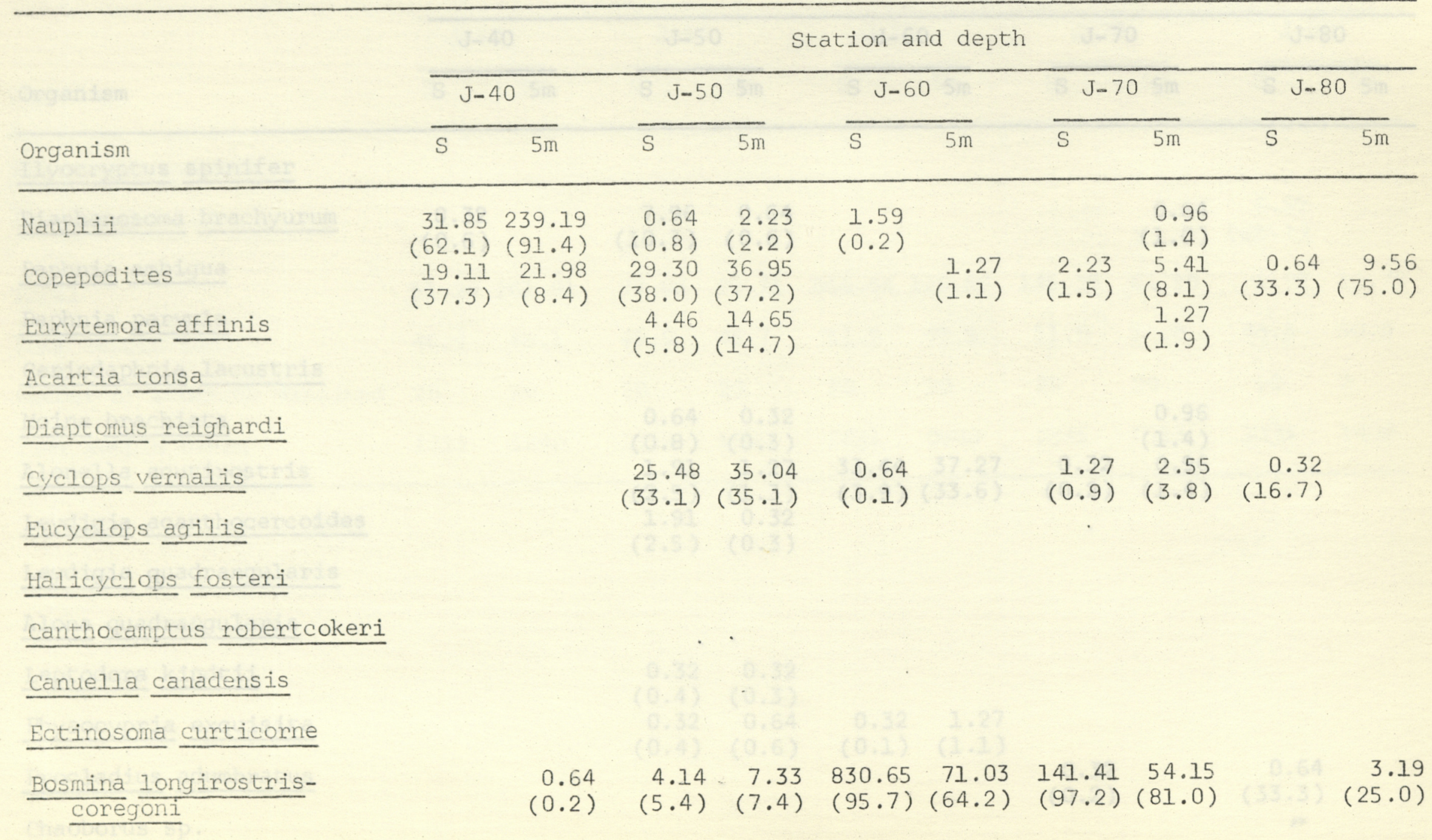


Table B3. (Continued).

Station and depth

Organism

\begin{tabular}{|c|c|c|c|c|}
\hline$J-40$ & $J-50$ & $J-60$ & $\mathrm{~J}-70$ & $J-80$ \\
\hline $5 m$ & $5 m$ & $5 m$ & $5 m$ & $5 \mathrm{~m}$ \\
\hline
\end{tabular}

Ilyocryptus spinifer

Diaphanosoma brachyurum

$\begin{array}{rrrr}0.32 & 7.96 & 0.64 & 0.64 \\ (0.6) & (10.3) & (0.6) & (1.0)\end{array}$

Daphnia ambigua

Daphnia parvula

Ceriodaphnia lacustris

Moina brachiata

Alonella acutirostris

Leydigia acanthocercoides

Leydigia quadrangularis

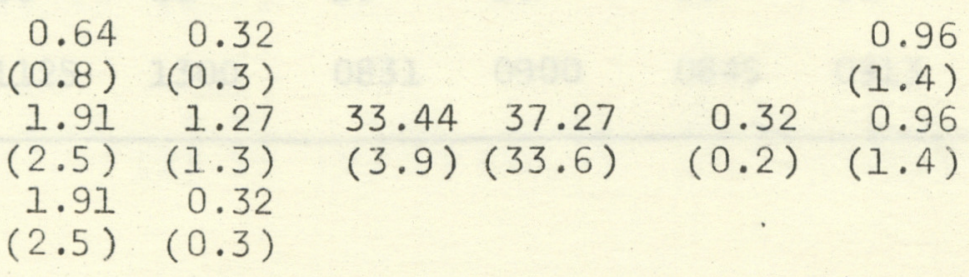

Alona quadrangularis

Leptodora kindtii

Physocypria exquisita

Procladius adumbratus

Chaoborus sp.

$\begin{array}{rrrrrr}0.32 & 0.32 & & & & \\ (0.4) & (0.3) & & & & \\ 0.32 & 0.64 & 0.32 & 1.27 & & 0.64 \\ (0.4) & (0.6) & (0.1) & (1.1) & & 0.32 \\ & & & & (0.2) & (33.3)\end{array}$




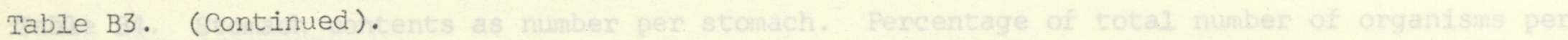

\begin{tabular}{|c|c|c|c|c|c|c|c|c|c|c|}
\hline \multirow[b]{3}{*}{ Organism } & \multicolumn{10}{|c|}{ Station and depth } \\
\hline & \multicolumn{2}{|c|}{$J-40$} & \multicolumn{2}{|c|}{$J-50$} & \multicolumn{2}{|c|}{$J-60$} & \multicolumn{2}{|c|}{$\mathrm{J}-70$} & \multicolumn{2}{|c|}{$\mathrm{J}-80$} \\
\hline & $S$ & $5 \mathrm{~m}$ & $\mathrm{~S}-1=$ & $5 m$ & $S$ & $5 \mathrm{~m}$ & $S$ & $5 m$ & $S$ & $5 \mathrm{~m}$ \\
\hline \multicolumn{11}{|l|}{ Pristina breviseta } \\
\hline Insecta (adult) & & & & & & & $30.69)$ & & $\begin{array}{r}0.32 \\
(16.7)\end{array}$ & \\
\hline Total & 51.28 & 261.81 & 77.08 & 99.71 & 866.64 & 110.84 & 145.55 & 66.90 & 1.92 & 12.75 \\
\hline Fork length (mm) & 46.9 & 46.1 & 48.8 & 48.7 & 51.9 & 49.9 & 51.0 & 51.0 & $48 \cdot 8$ & 50.0 \\
\hline Number of stomachs examined & 20 & 20 & 20 & 20 & 20 & 20 & 20 & 20 & 20 & 2 \\
\hline Time sample taken & 1213 & 1240 & 1125 & 1300 & 0831 & 0900 & 0845 & 0913 & 1335 & 1400 \\
\hline
\end{tabular}


Table B4. Stomach contents as number per stomach. Percentage of total number of organisms per stomach in parentheses. Date: 17-19 September 1969. S, surface; $5 \mathrm{~m}, 5$ meters

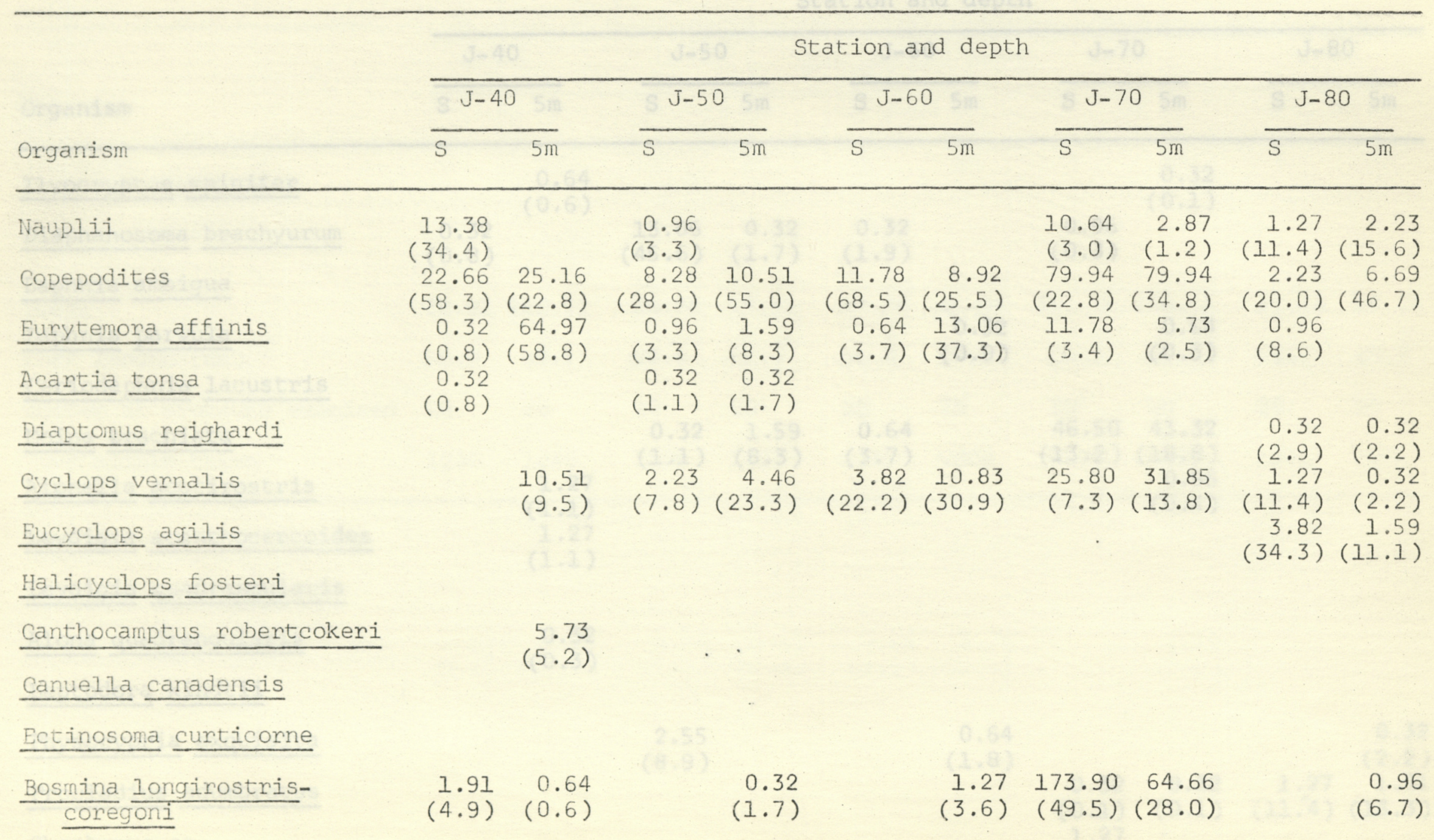


Table B4. (Continued).

Station and depth

Organism

$\frac{\mathrm{J}-40}{\mathrm{~S} 5 \mathrm{~m}} \frac{\mathrm{J}-50}{\mathrm{~S} \quad 5 \mathrm{~m}} \frac{\mathrm{J}-60}{\mathrm{~S} \quad 5 \mathrm{~m}} \quad \frac{\mathrm{J}-70}{\mathrm{~S}}$

IIyocryptus spinifer

Diaphanosoma brachyurum

0.32
$(0.8)$

0.64

$(0.6)$

$(0.8)$

$13.06 \quad 0.32$

$(45.6) \quad(1.7)$

(1.9)

0.32

Daphnia ambigua

Daphnia parvula

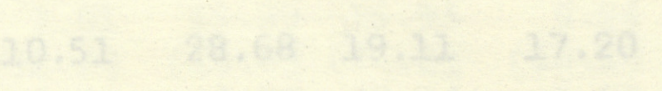

$\begin{array}{rr}0.32 & 0.64 \\ (0.9) & (0.3)\end{array}$

Ceriodaphnia lacustris

Moina brachiata

Alonella acutirostris

Leydigia acanthocercoides

Leydigia quadrangularis

Alona quadrangularis

Leptodora kindtii

Physocypria exquisita

Procladius adumbratus

\begin{tabular}{|c|c|c|c|c|c|c|c|c|}
\hline 1.27 & $\begin{array}{r}0.32 \\
(1.1)\end{array}$ & $\begin{array}{r}1.59 \\
(8.3)\end{array}$ & $\begin{array}{r}0.64 \\
(3.7)\end{array}$ & 0 & $\begin{array}{r}46.50 \\
(13.2)\end{array}$ & $\begin{array}{r}43.32 \\
(18.8) \\
0.96 \\
(0.4)\end{array}$ & 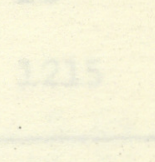 & $72=0$ \\
\hline $\begin{array}{r}1.17 \\
(1.1)\end{array}$ & & & & & . & & & \\
\hline $\begin{array}{r}0.32 \\
(0.3)\end{array}$ & • & . & & & & & & \\
\hline & $\begin{array}{r}2.55 \\
(8.9)\end{array}$ & & & $\begin{array}{r}0.64 \\
(1.8)\end{array}$ & $\begin{array}{r}0.32 \\
(0.1) \\
1.27 \\
(0.4)\end{array}$ & $\begin{array}{r}0.32 \\
(0.1)\end{array}$ & $\begin{array}{r}1.27 \\
(11.4)\end{array}$ & $\begin{array}{r}0.32 \\
(2.2) \\
1.91 \\
(13.3)\end{array}$ \\
\hline
\end{tabular}

Chaoborus sp. 
Table B4. (Continued).

\begin{tabular}{|c|c|c|c|c|c|c|c|c|c|c|}
\hline \multirow[b]{3}{*}{ Organism } & \multicolumn{10}{|c|}{ Station and depth } \\
\hline & \multicolumn{2}{|c|}{$\mathrm{J}-40$} & \multicolumn{2}{|c|}{$J-50$} & \multicolumn{2}{|c|}{$J-60$} & \multicolumn{2}{|c|}{$\mathrm{J}-70$} & \multicolumn{2}{|c|}{$\mathrm{J}-80$} \\
\hline & $\mathrm{S} y+-$ & $5 \mathrm{~m}$ & S & $5 m$ & $\mathrm{~S}$ & $5 m$ & $S$ & $5 m$ & $S$ & $\overline{5 m}$ \\
\hline \multicolumn{11}{|l|}{ Pristina breviseta } \\
\hline Insecta (adult) & & & & & & & & & & \\
\hline Total & 38.91 & 110.51 & 28.68 & 19.11 & 17.20 & 35.04 & 351.11 & 230.61 & 11.14 & 14.34 \\
\hline Fork length (mn) & 50.0 & 63.1 & $52 \cdot 6$ & 51.7 & 55.0 & 54.8 & 60.2 & 60.7 & 59.5 & 60.2 \\
\hline Number of stomachs examined & 20 & 20 & 20 & 20 & 20 & 20 & $20^{\prime}$ & 20 & 20 & 20 \\
\hline Time sample taken & 1200 & 1240 & 1105 & 1133 & 0735 & 0800 & 0820 & 0850 & 1215 & 1241 \\
\hline
\end{tabular}


Table B5. Stomach contents as number per stomach. Percentage of total number of organisms per stomach in parentheses. Date: 28-30 October 1969. S, surface; $5 \mathrm{~m}, 5$ meters

\begin{tabular}{|c|c|c|c|c|c|c|c|c|c|c|}
\hline \multirow[b]{3}{*}{ Organism } & \multicolumn{2}{|c|}{$3-40$} & \multicolumn{4}{|c|}{ Station and depth } & \multicolumn{2}{|c|}{$3-70$} & \multicolumn{2}{|l|}{$x^{3}=92$} \\
\hline & \multicolumn{2}{|c|}{$J-40$} & \multicolumn{2}{|c|}{ J-50 } & \multicolumn{2}{|c|}{$J-60$} & \multicolumn{2}{|c|}{$\mathrm{J}-70$} & \multicolumn{2}{|c|}{$\mathrm{J}-80$} \\
\hline & $S$ & $5 m$ & S & $5 m$ & S & $5 m$ & $S$ & $5 m$ & S & $\overline{5 m}$ \\
\hline $\begin{array}{l}\text { Nauplii } \\
\text { Copepodites } \\
\text { Eurytemora affinis } \\
\text { Acartia tonsa }\end{array}$ & $\begin{array}{r}11.78 \\
(33.8) \\
14.33 \\
(40.9) \\
1.27 \\
(3.6)\end{array}$ & $\begin{array}{r}1.59 \\
(7.3) \\
7.01 \\
(32.3) \\
0.32 \\
(1.5)\end{array}$ & $\begin{array}{r}15.29 \\
(19.6) \\
49.37 \\
(63.3)\end{array}$ & $\begin{array}{r}15.93 \\
(24.9) \\
29.94 \\
(46.8)\end{array}$ & $\begin{array}{r}9.24 \\
(36.8) \\
1.91 \\
(7.6)\end{array}$ & $\begin{array}{r}5.41 \\
(34.0)\end{array}$ & $\begin{array}{r}8.60 \\
(2.4) \\
3.50 \\
(1.0)\end{array}$ & $\begin{array}{l}15.61 \\
(7.6) \\
36.00 \\
(17.6)\end{array}$ & $\begin{array}{r}18.79 \\
(37.3) \\
1.27 \\
(2.5)\end{array}$ & $\begin{array}{l}3.19 \\
(5.9)\end{array}$ \\
\hline Diaptomus reighardi & & & & & & & & & & \\
\hline $\begin{array}{l}\text { Cyclops vernalis } \\
\text { Eucyclops agilis }\end{array}$ & & $\begin{array}{r}0.32 \\
(1.5)\end{array}$ & $\begin{array}{r}8.28 \\
(10.6)\end{array}$ & $\begin{array}{r}6.69 \\
(10.4)\end{array}$ & $\begin{array}{r}0.32 \\
(1.3)\end{array}$ & & $\begin{array}{r}0.96 \\
(0.3) \\
\end{array}$ & $\begin{array}{r}4.14 \\
(2.0)\end{array}$ & $\begin{array}{r}0.64 \\
(1.3) \\
29.30 \\
(58.3)\end{array}$ & $\begin{array}{r}47.78 \\
(88.2)\end{array}$ \\
\hline Canthocamptus robertcokeri & $\begin{array}{l}1.27 \\
(3.6)\end{array}$ & $\begin{array}{r}2.87 \\
(13.2)\end{array}$ & $\begin{array}{r}4.14 \\
(5.3)\end{array}$ & $\begin{array}{r}8.28 \\
(12.9)\end{array}$ & $\begin{array}{r}0.64 \\
(2.5)\end{array}$ & $\begin{array}{r}3.50 \\
(22.0)\end{array}$ & & $\begin{array}{l}1.59 \\
(0.8)\end{array}$ & & \\
\hline Canuella canadens is & & & & & & & & & & \\
\hline $\begin{array}{l}\text { Ectinosoma curticone } \\
\frac{\text { Bosmina }}{\text { conegoni }}\end{array}$ & $\begin{array}{l}1.59 \\
(4.5) \\
4.78 \\
(13.6)\end{array}$ & $\begin{array}{r}0.64 \\
(3.0) \\
8.92 \\
(41.2)\end{array}$ & & $\begin{array}{r}2.55 \\
(4.0)\end{array}$ & $\begin{array}{r}11.78 \\
(46.8)\end{array}$ & $\begin{array}{r}6.37 \\
(40.0)\end{array}$ & $\begin{array}{l}336.65 \\
(93.2)\end{array}$ & $\begin{array}{l}135.68 \\
(66.3)\end{array}$ & & \\
\hline
\end{tabular}


Table B5. (continued).

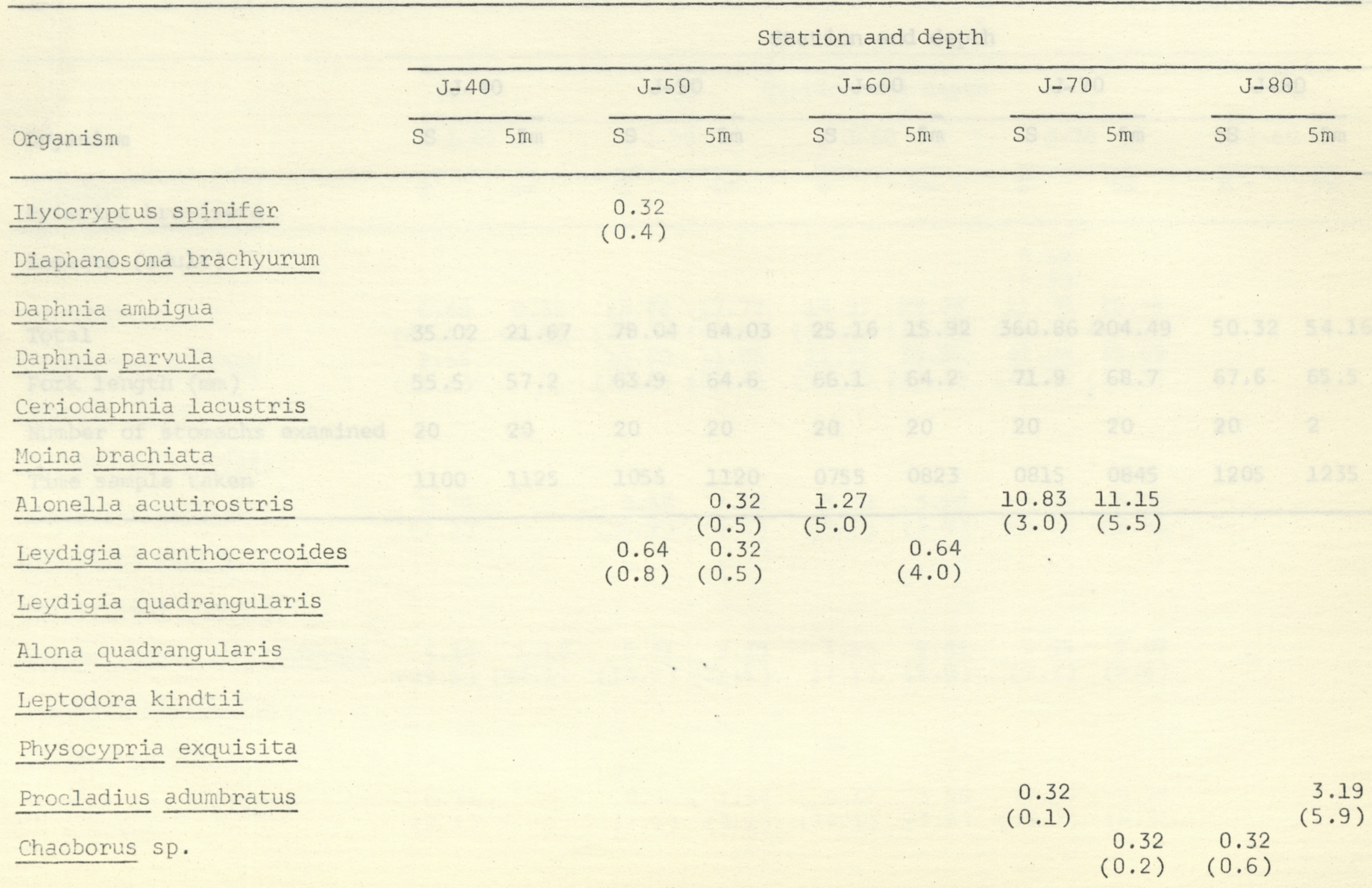


Table B5. (Continued). nts as nubber pexp stomach. Percentage of total number of onganisms per

\begin{tabular}{|c|c|c|c|c|c|c|c|c|c|c|}
\hline \multirow[b]{3}{*}{ Organism } & \multicolumn{10}{|c|}{ Station and depth } \\
\hline & \multicolumn{2}{|l|}{$\mathrm{J}-40$} & \multicolumn{2}{|l|}{$\mathrm{J}-50$} & \multicolumn{2}{|l|}{$J-60$} & \multicolumn{2}{|c|}{$\mathrm{J}-70$} & \multicolumn{2}{|c|}{$\mathrm{J}-80$} \\
\hline & $S$ & $5 \mathrm{~m}$ & $S$ & $5 m$ & $S$ & $5 m$ & $S$ & $5 \mathrm{~m}$ & $S$ & $5 m$ \\
\hline \multicolumn{11}{|l|}{ Pristina breviseta } \\
\hline Insecta (adult) & & & & & & & & & & \\
\hline Total & 35.02 & 21.67 & 78.04 & 64.03 & 25.16 & 15.92 & 360.86 & 204.49 & 50.32 & 54.16 \\
\hline Fork length (mm) & 55.5 & 57.2 & 63.9 & 64.6 & 66.1 & 64.2 & 71.9 & 68.7 & 67.6 & 65.5 \\
\hline Number of stomachs examined & 20 & 20 & 20 & 20 & 20 & 20 & 20 & 20 & 20 & 2 \\
\hline Time sample taken & 1100 & 1125 & 1055 & 1120 & 0755 & 0823 & 0815 & 0845 & 1205 & 1235 \\
\hline
\end{tabular}


Table B6. Stomach contents as number per stomach. Percentage of total number of organisms per stomach in parentheses. Date: 18-20 November 1969. S, surface; $5 \mathrm{~m}, 5$ meters

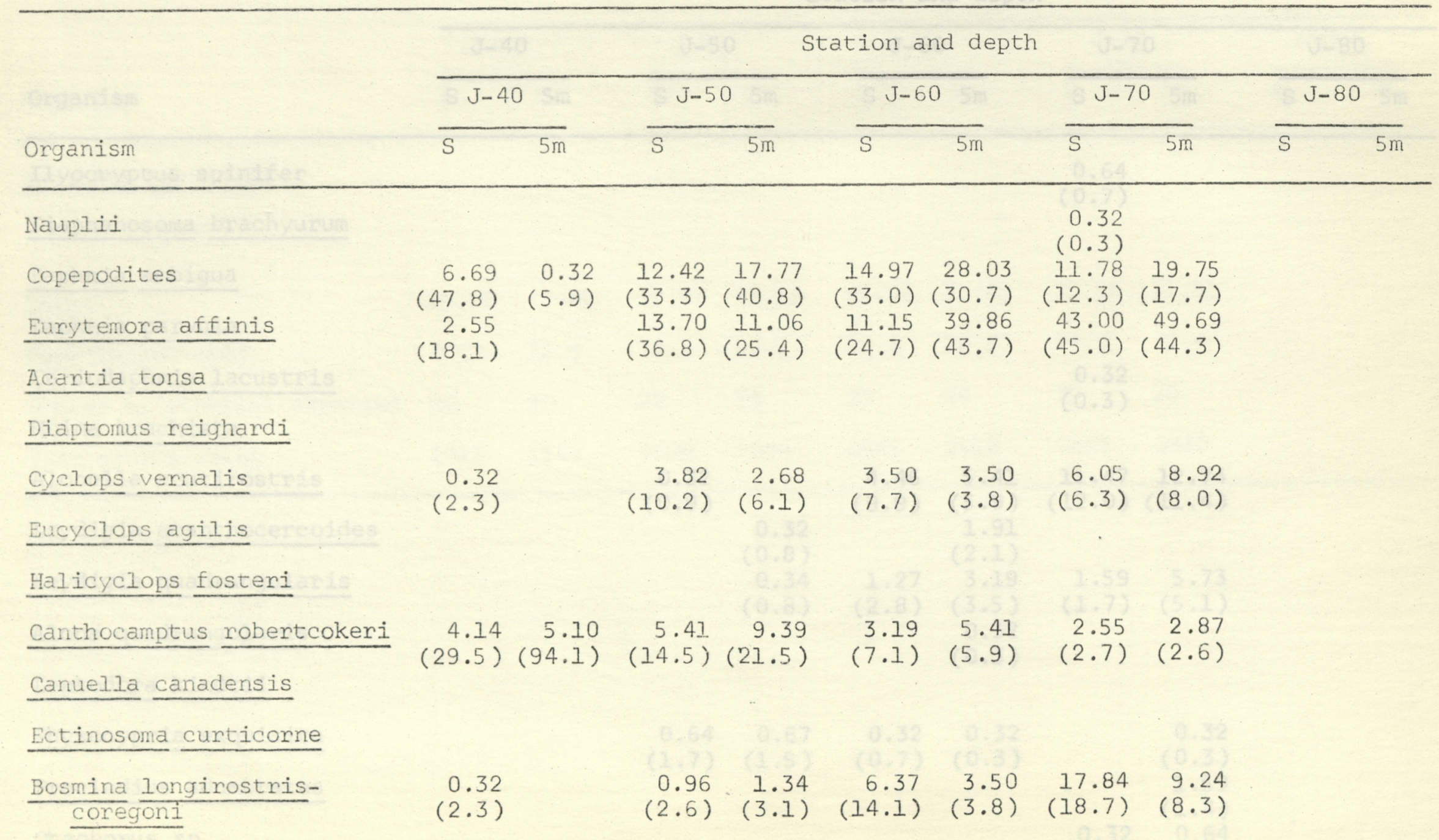


Table B6. (Continued).

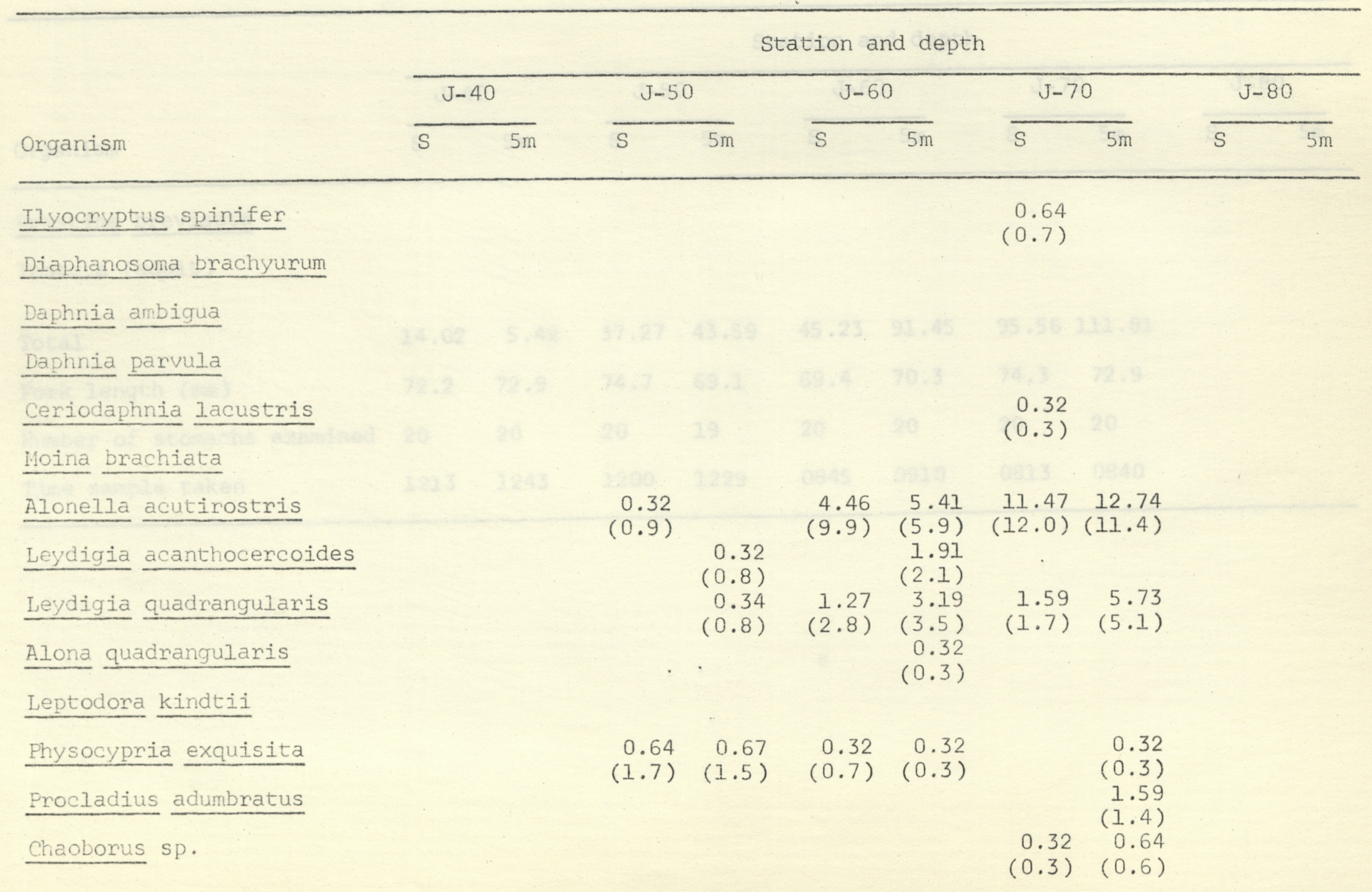


Table B6. (Continued).

\begin{tabular}{|c|c|c|c|c|c|c|c|c|c|c|}
\hline \multirow[b]{3}{*}{ Organism } & \multicolumn{10}{|c|}{ Station and depth } \\
\hline & \multicolumn{2}{|c|}{$\mathrm{J}-40$} & \multicolumn{2}{|c|}{$\mathrm{J}-50$} & \multicolumn{2}{|c|}{$J-60$} & \multicolumn{2}{|c|}{$\mathrm{J}-70$} & \multicolumn{2}{|c|}{$J-80$} \\
\hline & $S$ & $5 m$ & $S$ & $5 m$ & $S$ & $5 \mathrm{~m}$ & $S$ & $5 m$ & $S$ & $5 m$ \\
\hline \multicolumn{11}{|l|}{ Pristina breviseta } \\
\hline \multicolumn{11}{|l|}{ Insecta (adult) } \\
\hline Total & 14.02 & 5.42 & 37.27 & 43.59 & 45.23 & 91.45 & 95.56 & 111.81 & & \\
\hline Fork length ( $\mathrm{mm})$ & 72.2 & 72.9 & 74.7 & 69.1 & 69.4 & 70.3 & 74.3 & 72.9 & & \\
\hline Number of stomachs examined & 20 & 20 & 20 & 19 & 20 & 20 & 20 & 20 & & \\
\hline Time sample taken & 1213 & 1243 & 1200 & 1229 & 0845 & 0910 & 0813 & 0840 & & \\
\hline
\end{tabular}


Appendix C

Electivity (E) 
Table Cl. Selection (Electivity of IVlev, 1961) of zooplankton by young-of-the-year blueback herring. Date: 16-19 June 1969. S, surface; $5 \mathrm{~m}, 5$ meters

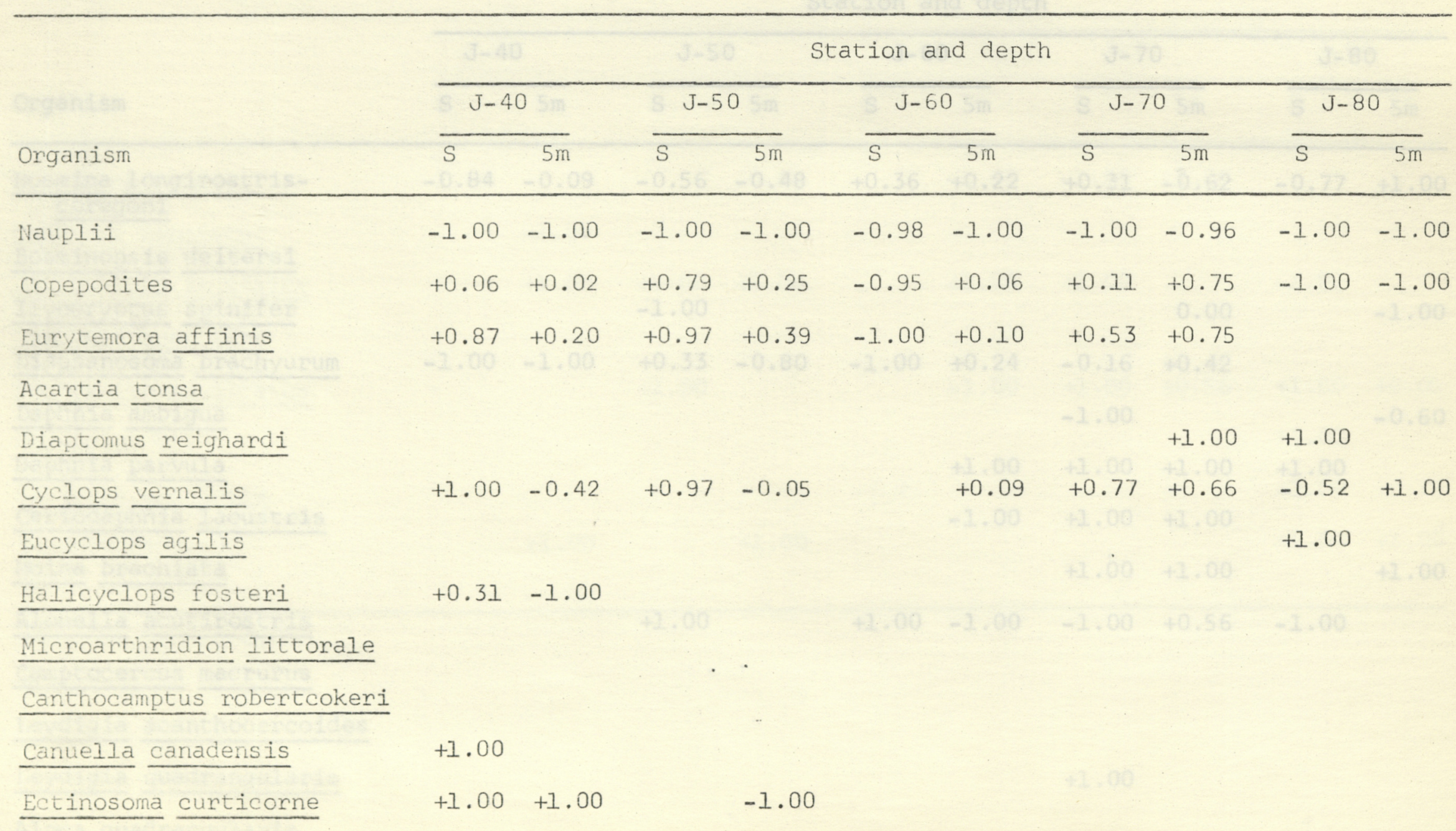


Table Cl. (Continued).

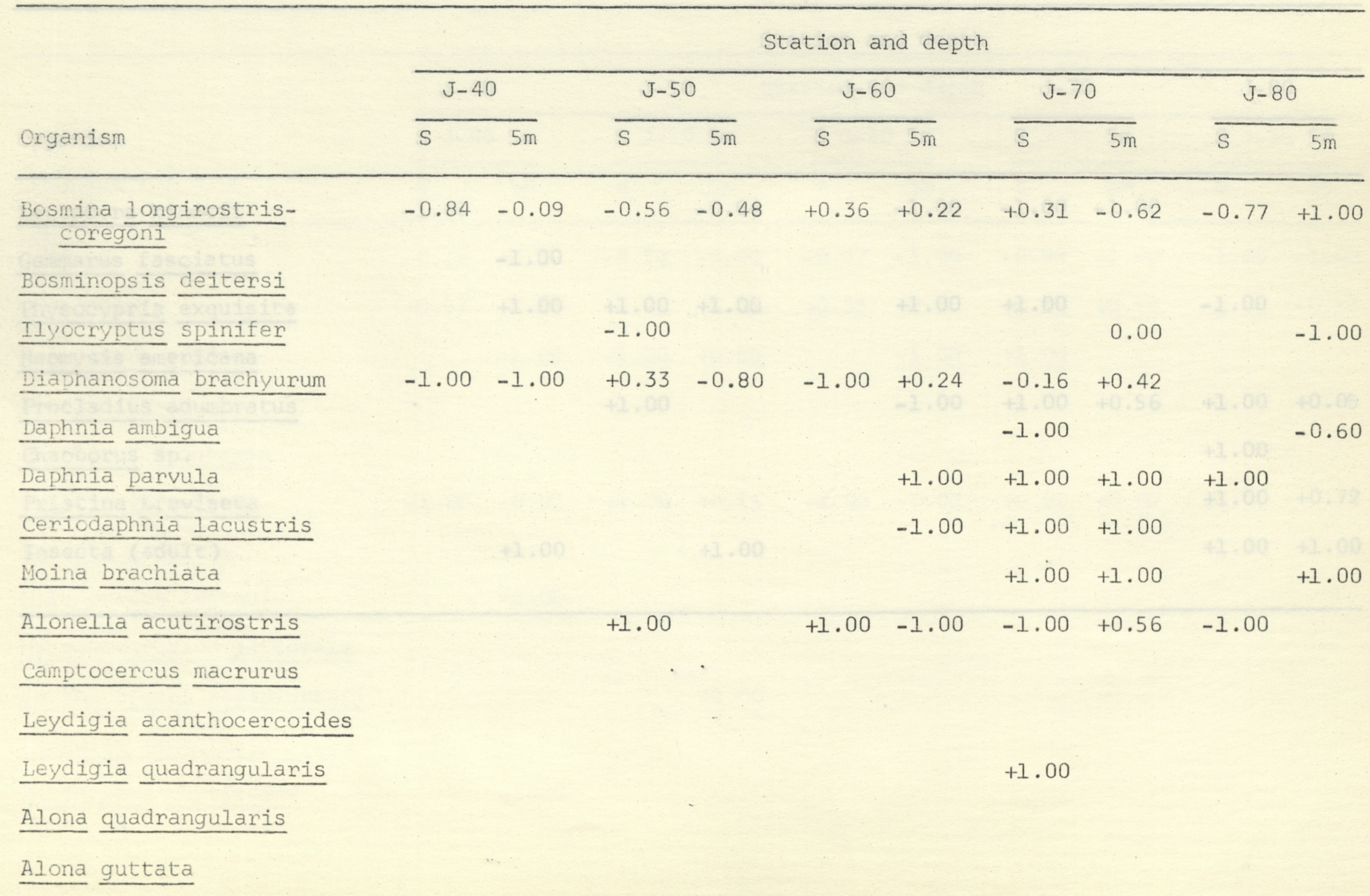


Table $\mathrm{Cl}$. (Continued).

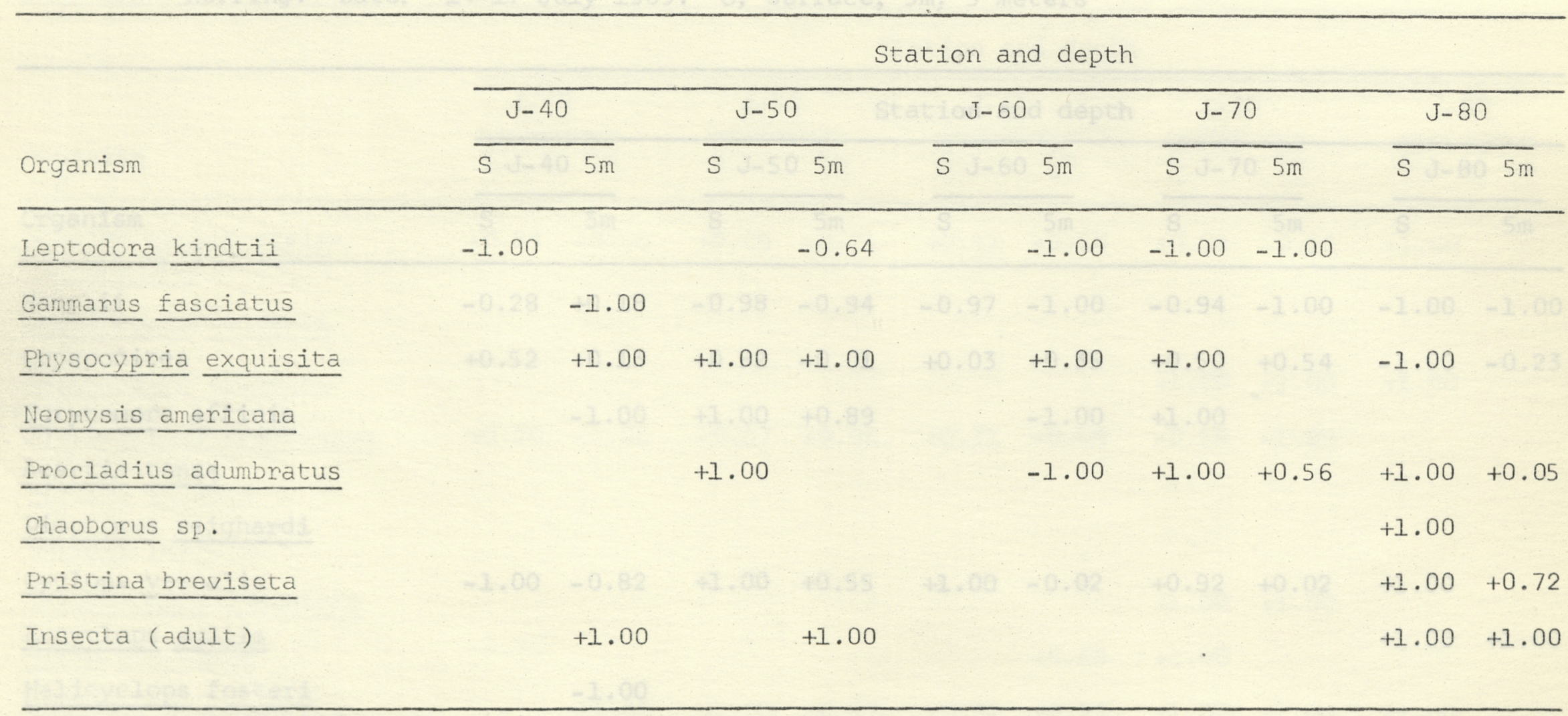


Table C2. Selection (Electivity of IVlev, 1961) of zooplankton by young-of-the-year blueback herring. Date: $14-17$ July 1969. S, surface; $5 \mathrm{~m}, 5$ meters

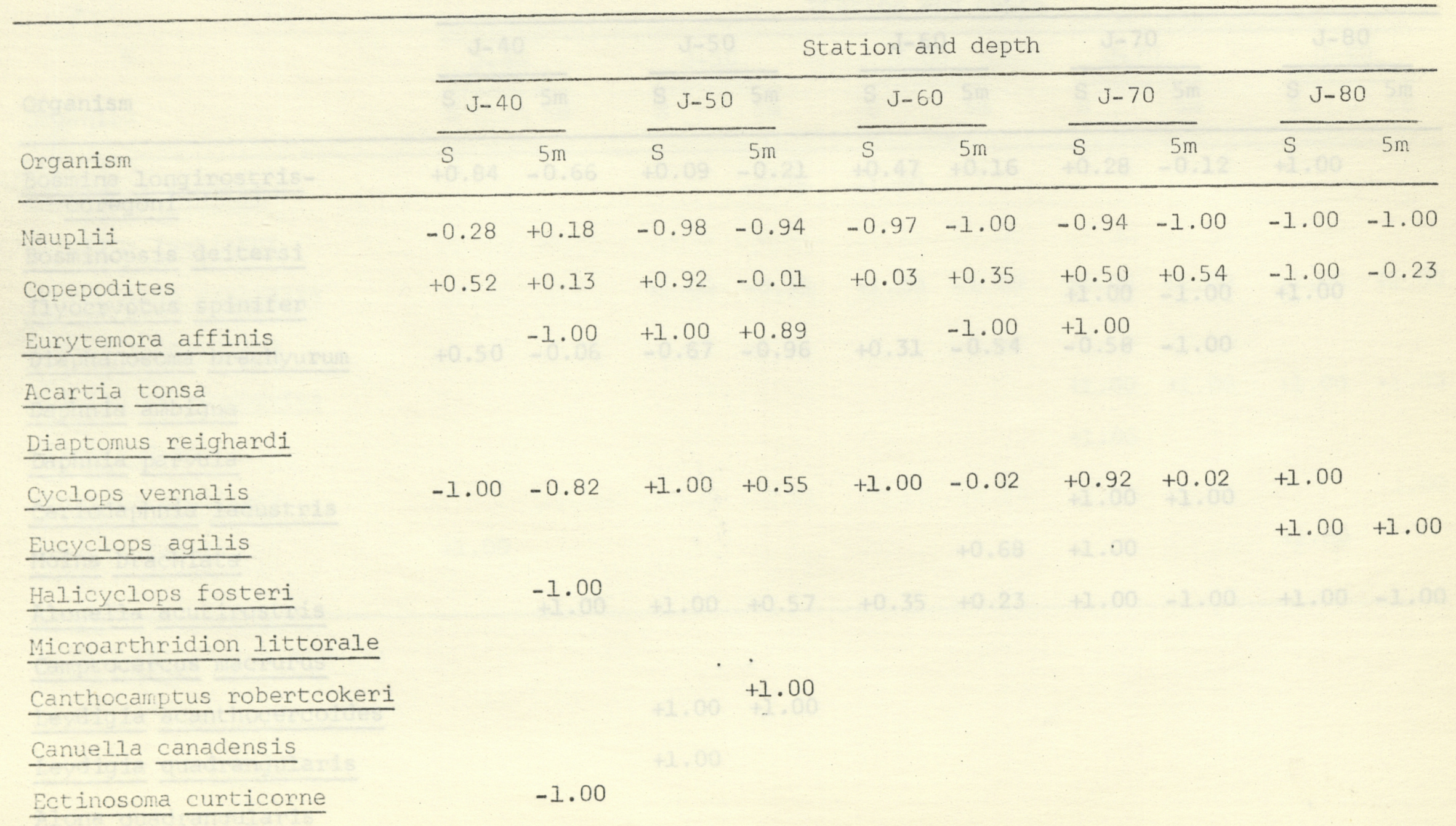


Table c2. (continued).

\begin{tabular}{|c|c|c|c|c|c|c|c|c|c|c|}
\hline \multirow[b]{3}{*}{ Organism } & \multicolumn{10}{|c|}{ Station and depth } \\
\hline & \multicolumn{2}{|c|}{$\mathrm{J}-40$} & \multicolumn{2}{|c|}{$\mathrm{J}-50$} & \multicolumn{2}{|c|}{$J-60$} & \multicolumn{2}{|c|}{$\mathrm{J}-70$} & \multicolumn{2}{|c|}{$\mathrm{J}-80$} \\
\hline & S & $5 m$ & $S$ & $5 m$ & $S$ & $5 m$ & S & $5 m$ & S & $5 \mathrm{~m}$ \\
\hline$\frac{\text { Bosmina longirostris- }}{\text { coregoni }}$ & +0.84 & -0.66 & +0.09 & -0.21 & +0.47 & +0.16 & +0.28 & -0.12 & +1.00 & \\
\hline \multicolumn{11}{|l|}{ Bosminopsis deitersi } \\
\hline Ilyocryptus spinifer & & & & $2+0.33$ & & $-1+109$ & +1.00 & -1.00 & +1.00 & \\
\hline Diaphanosoma brachyurum & +0.50 & -0.06 & -0.67 & -0.96 & +0.31 & -0.54 & -0.58 & -1.00 & & \\
\hline Daphnia ambigua & & & & & & & +12.00 & & & $=$ \\
\hline Daphnia parvula & & & & & & & & & & \\
\hline Ceriodaphnia lacustris & & & & & & & +1.00 & +1.00 & & \\
\hline Moina brachiata & & & $\because$ & & & +0.68 & +1.00 & & $4+1.04$ & \\
\hline Alonella acutirostris & & +1.00 & +1.00 & +0.57 & +0.35 & +0.23 & +1.00 & -1.00 & +1.00 & -1.00 \\
\hline Camptocercus macrurus & & & . & $\cdot$ & & & & & & \\
\hline Leydigia acanthocercoides & & & +1.00 & +1.00 & & & & & & \\
\hline Leydigia quadrangularis & & & +1.00 & & & & & & & \\
\hline Alona quadrangularis & & & & & & & & & & \\
\hline Alona guttata & & & & & & & & & & \\
\hline
\end{tabular}


Table C2. (Continued)

\begin{tabular}{|c|c|c|c|c|c|c|c|c|c|}
\hline \multirow[b]{3}{*}{ Organism } & \multicolumn{9}{|c|}{ Station and depth } \\
\hline & $\mathrm{J}-40$ & \multicolumn{2}{|c|}{$\mathrm{J}-50$} & \multicolumn{2}{|c|}{$\mathrm{J}-60$} & \multicolumn{2}{|c|}{$\mathrm{J}-70$} & \multicolumn{2}{|c|}{$\mathrm{J}-80$} \\
\hline & $S \quad 5 m$ & S & $5 m$ & $S$ & $5 m$ & S & $5 \mathrm{~m}$ & $S$ & $5 \mathrm{~m}$ \\
\hline Leptodora kindtii & & & -0.25 & -1.00 & & 8 & & 5 & \\
\hline Gammarus fasciatus & & $-0 \cdot x^{2}=$ & $-3.9+4$ & & -2.00 & -1.00 & -0.949 & & 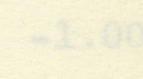 \\
\hline Physocypria exquisita & & +1.00 & +0.33 & +1.00 & -1.00 & +1.00 & +1.00 & +1.00 & +1.00 \\
\hline Neonysis americana & & $+2+28$ & & & $-2=00$ & -3.00 & $\sqrt{20}+30$ & & \\
\hline Procladius adumbratus & & & & & & +1.00 & +1.00 & +1.00 & +1.00 \\
\hline Chaoborus Sp. & & & & & & +1.00 & & & \\
\hline Pristina breviseta & & & 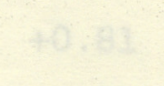 & & & & & & -1.00 \\
\hline Insecta (adult) & +1.00 & & & & & . & & +1.00 & \\
\hline
\end{tabular}


Table c3. Selection (Electivity of IVlev, 1961) of zooplankton by young-of-the-year blueback herring. Date: 18-21 August 1969. S, surface; $5 \mathrm{~m}, 5$ meters

\begin{tabular}{|c|c|c|c|c|c|c|c|c|c|c|}
\hline \multirow[b]{3}{*}{ Organism } & \multirow{2}{*}{\multicolumn{2}{|c|}{$\mathrm{J}-40$}} & \multirow{2}{*}{\multicolumn{4}{|c|}{ Station and depth }} & \multirow{2}{*}{\multicolumn{2}{|c|}{$\mathrm{J}-70$}} & \multirow{2}{*}{\multicolumn{2}{|c|}{$\mathrm{J}-80$}} \\
\hline & & & & & & & & & & \\
\hline & S & $5 \mathrm{~m}$ & $S$ & $5 m$ & $\mathrm{~S}$ & $5 \mathrm{~m}$ & S & $5 m$ & S & $5 m$ \\
\hline Nauplii & -0.12 & +0.65 & -0.98 & -0.91 & -0.99 & -1.00 & -1.00 & -0.84 & -1.00 & -1.00 \\
\hline Copepodites & +0.48 & -0.60 & +0.40 & +0.08 & -1.00 & -0.82 & -0.71 & -0.07 & -0.13 & +0.23 \\
\hline Eurytemora affinis & & -1.00 & +0.78 & +0.55 & & -1.00 & -1.00 & +0.19 & & \\
\hline \multirow{2}{*}{\multicolumn{11}{|c|}{$\begin{array}{l}\text { Acartia tonsa } \\
\text { Diaptomus reighardi }\end{array}$}} \\
\hline & & & & & & & & & & \\
\hline Cyclops vernalis & & -1.00 & +0.97 & +0.81 & -0.50 & -1.00 & +1.00 & -0.07 & & \\
\hline Eucyclops agilis & & & & & & & $\cdot$ & & +1.00 & \\
\hline Halicyclops fosteri & & -1.00 & & & & & & & & \\
\hline Microarthridion littorale & & & . & . & & & & & & \\
\hline Canthocamptus robertcokeri & & & & -2.00 & & & & & & \\
\hline Canuella canadensis & & & & & & & & & & \\
\hline Ectinosoma curticorne & & & -1.00 & & & & & & & \\
\hline
\end{tabular}


Table C3. (continued).

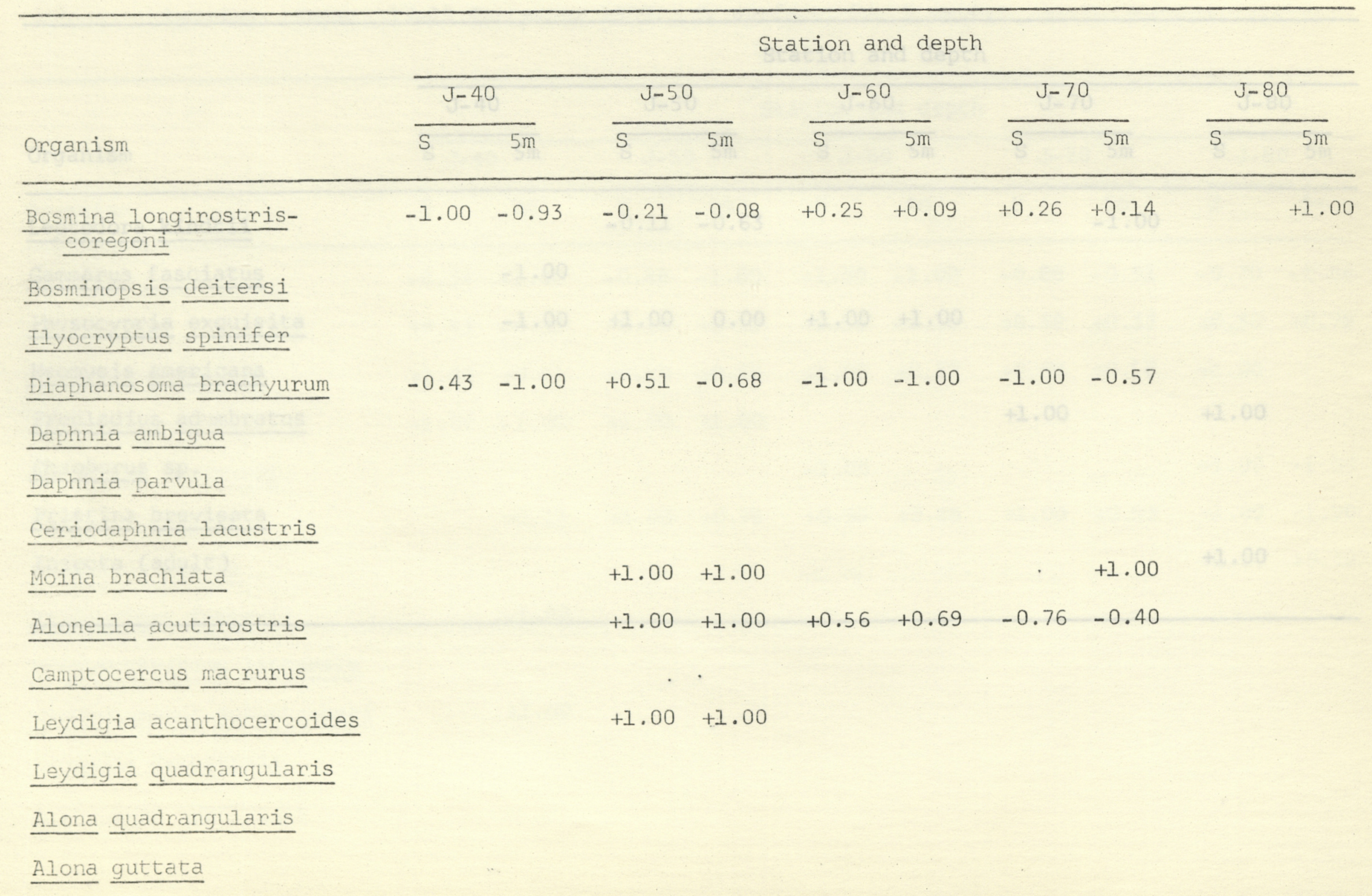


Table C3. (Continued). ectivity of Tulev, 1967) of zooplankton by young-of-the-yean blueback

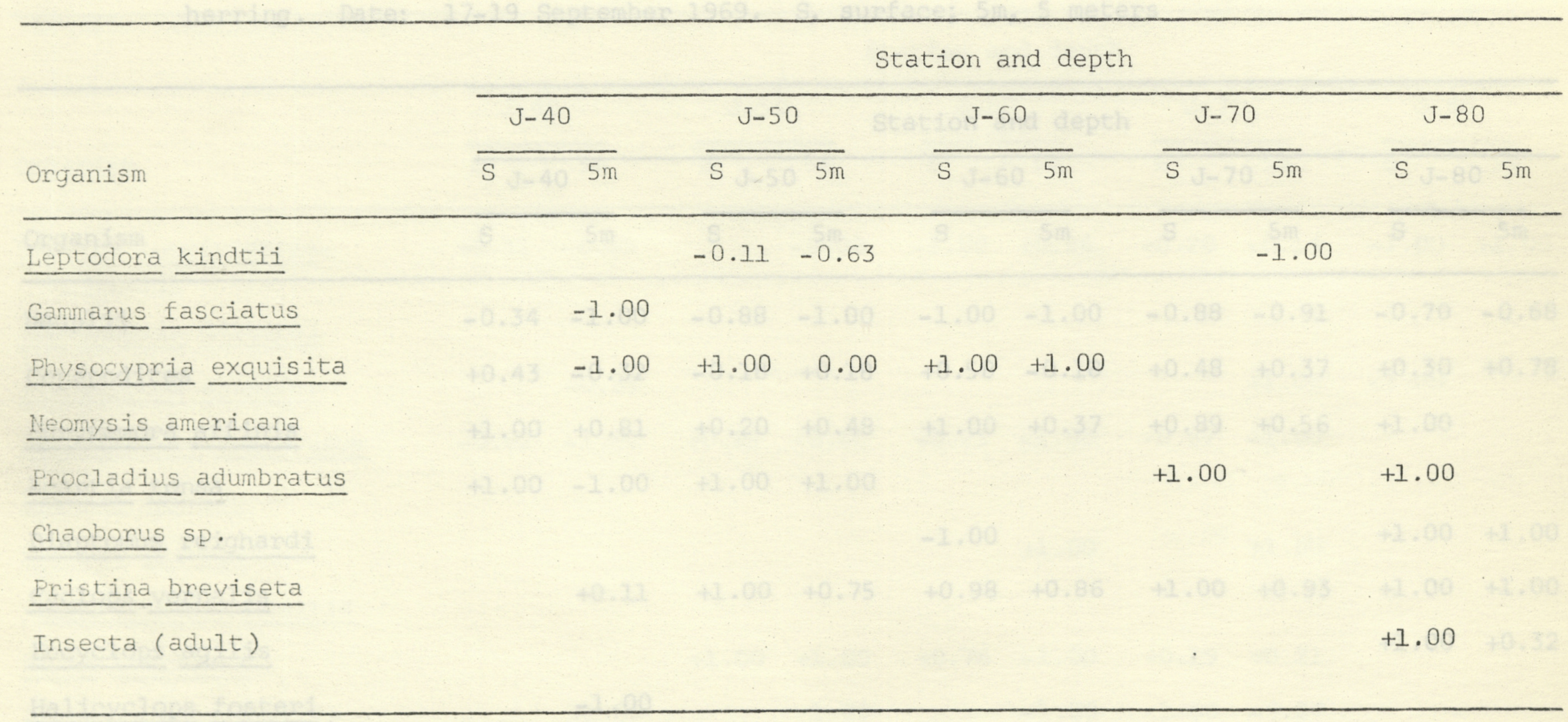


Table C4. Selection (Electivity of IVlev, 1961) of zooplankton by young-of-the-year blueback herring. Date: 17-19 September 1969. S, surface; 5m, 5 meters

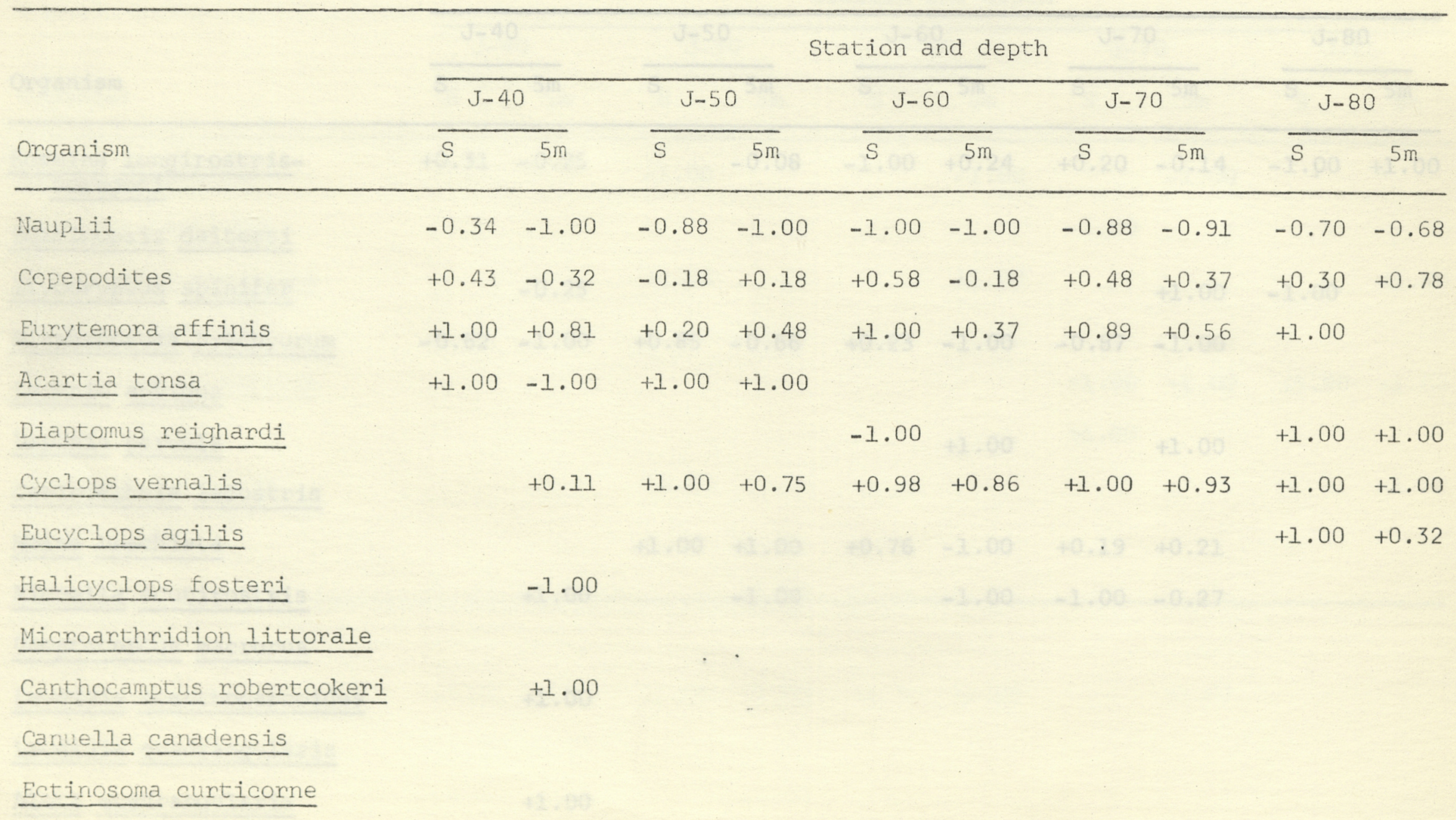


Table C4. (Continued).

\begin{tabular}{|c|c|c|c|c|c|c|c|c|c|c|}
\hline \multirow[b]{3}{*}{ Organism } & \multicolumn{10}{|c|}{ Station and depth } \\
\hline & \multicolumn{2}{|c|}{$J-40$} & \multicolumn{2}{|c|}{$\mathrm{J}-50$} & \multicolumn{2}{|c|}{$J-60$} & \multicolumn{2}{|c|}{$J-70$} & \multicolumn{2}{|c|}{$J-80$} \\
\hline & $S$ & $5 m$ & $S$ & $5 \mathrm{~m}$ & $S$ & $5 m$ & $\mathrm{~s}$ & $5 \mathrm{~m}$ & $S$ & $5 \mathrm{~m}$ \\
\hline$\frac{\text { Bosmina }}{\text { coregoni }}$ & +0.31 & -0.25 & & -0.08 & -1.00 & +0.24 & +0.20 & -0.14 & -1.00 & +1.00 \\
\hline \multicolumn{11}{|l|}{ Bosminopsis deitersi } \\
\hline Ilyocryptus spinifer & & -0.25 & & & & $-2 \cdot 00$ & & +1.00 & -1.00 & \\
\hline Diaphanosoma brachyurum & -0.62 & -1.00 & +0.85 & -0.66 & +0.23 & -1.00 & -0.87 & -1.00 & & \\
\hline \multicolumn{11}{|l|}{ Daphnia ambigua } \\
\hline Daphnia parvula & & & & & & +1.00 & & +1.00 & & \\
\hline \multicolumn{11}{|l|}{ Ceriodaphnia lacustris } \\
\hline Moina brachiata & & & +1.00 & +1.00 & +0.76 & -1.00 & +0.19 & +0.21 & & \\
\hline Alonella acutirostris & & +1.00 & & -1.00 & & -1.00 & -1.00 & -0.27 & & \\
\hline \multicolumn{11}{|l|}{ Camptocercus macrurus } \\
\hline Leydigia acanthocercoides & & +1.00 & & . & & & & & & \\
\hline \multicolumn{11}{|l|}{ Leydigia quadrangularis } \\
\hline Alona quadrangularis & & +1.00 & & & & & & & & \\
\hline Alona guttata & & & & & & & & & & \\
\hline
\end{tabular}


Table C4. (Continued).

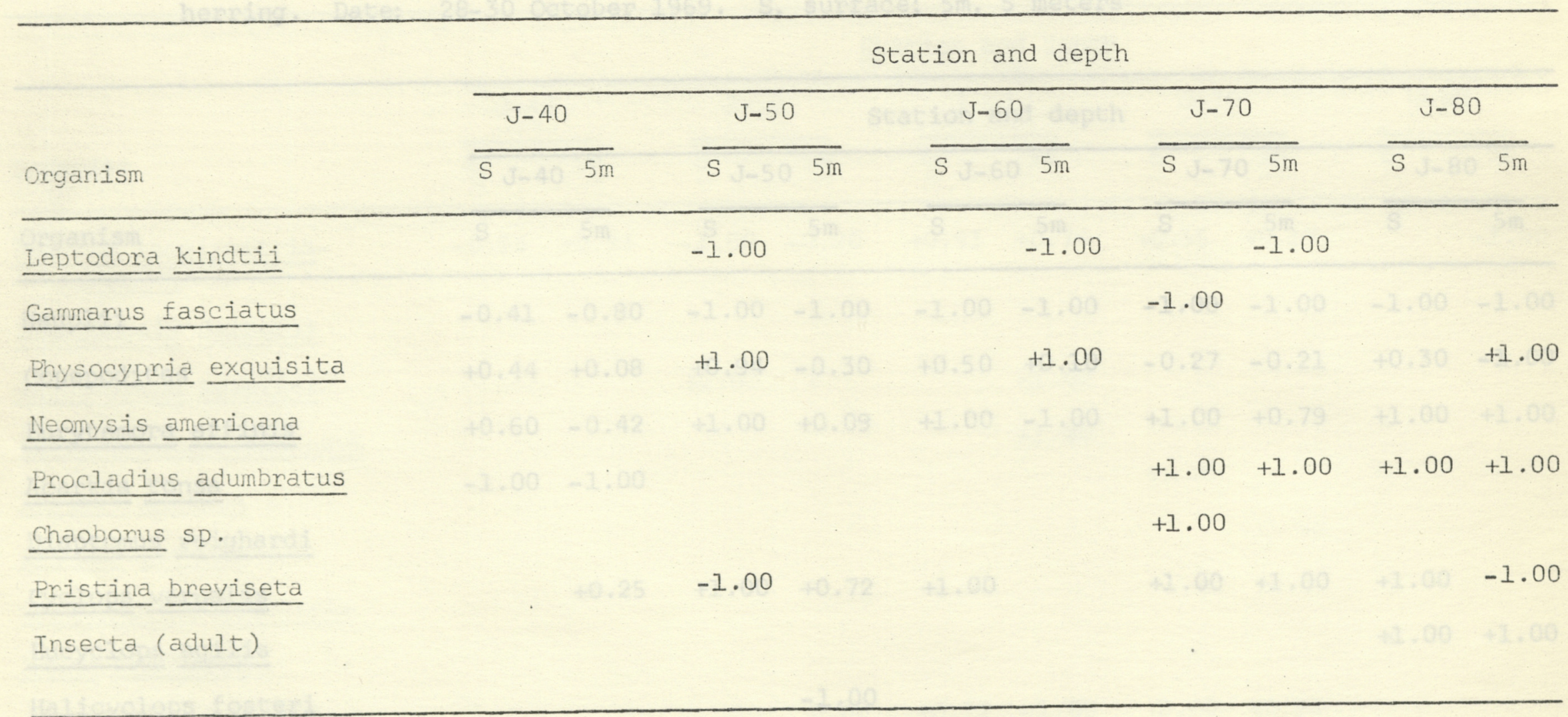


Table C5. Selection (Electivity of IVlev, 1961) of zooplankton by young-of-the-year blueback herring. Date: 28-30 October 1969. S, surface; $5 \mathrm{~m}, 5$ meters

\begin{tabular}{|c|c|c|c|c|c|c|c|c|c|c|}
\hline \multirow[b]{3}{*}{ Organism } & \multirow{2}{*}{\multicolumn{2}{|c|}{$J-40$}} & \multirow{2}{*}{\multicolumn{4}{|c|}{ Station and depth }} & \multirow{2}{*}{\multicolumn{2}{|c|}{$\frac{5-70}{J-70}$}} & \multirow{2}{*}{\multicolumn{2}{|c|}{$J-80$}} \\
\hline & & & & & & & & & & \\
\hline & $\mathrm{S}$ & $5 \mathrm{~m}$ & $\mathrm{~S}$ & $5 m$ & $\bar{S}$ & $5 \mathrm{~m}$ & $\mathrm{~s}$ & $5 m$ & S & $5 \mathrm{~m}$ \\
\hline Nauplii & -0.41 & -0.80 & -1.00 & -1.00 & -1.00 & -1.00 & -1.00 & -1.00 & -1.00 & -1.00 \\
\hline Copepodites & +0.44 & +0.08 & +0.94 & -0.30 & +0.50 & +0.10 & -0.27 & -0.21 & +0.30 & -1.00 \\
\hline Eurytemora affinis & +0.60 & -0.42 & +1.00 & +0.09 & +1.00 & -1.00 & +1.00 & +0.79 & +1.00 & +1.00 \\
\hline $\begin{array}{l}\text { Acartia tonsa } \\
\text { Diaptomus reighardi }\end{array}$ & -1.00 & -1.00 & & & & & & & & \\
\hline Cyclops vernalis & & +0.25 & +1.00 & +0.72 & +1.00 & & +1.00 & +1.00 & +1.00 & \\
\hline Eucyclops agilis & & & & & & & . & & +1.00 & +1.00 \\
\hline Halicyclops fosteri & & & & -1.00 & $+0+72$ & $-1 \times 00$ & & & & \\
\hline Microanthridion littorale & & & & . & & & & & & \\
\hline Canthocamptus robertcokeri & +1.00 & +1.00 & +1.00 & +1.00 & +1.00 & +1.00 & & +1.00 & & \\
\hline Canuella canadensis & -1.00 & -1.00 & & & & & & & & \\
\hline Ectinosoma curticorne & +0.88 & +0.54 & & -1.00 & & & & & & \\
\hline
\end{tabular}


Tabie C5. (Continued).

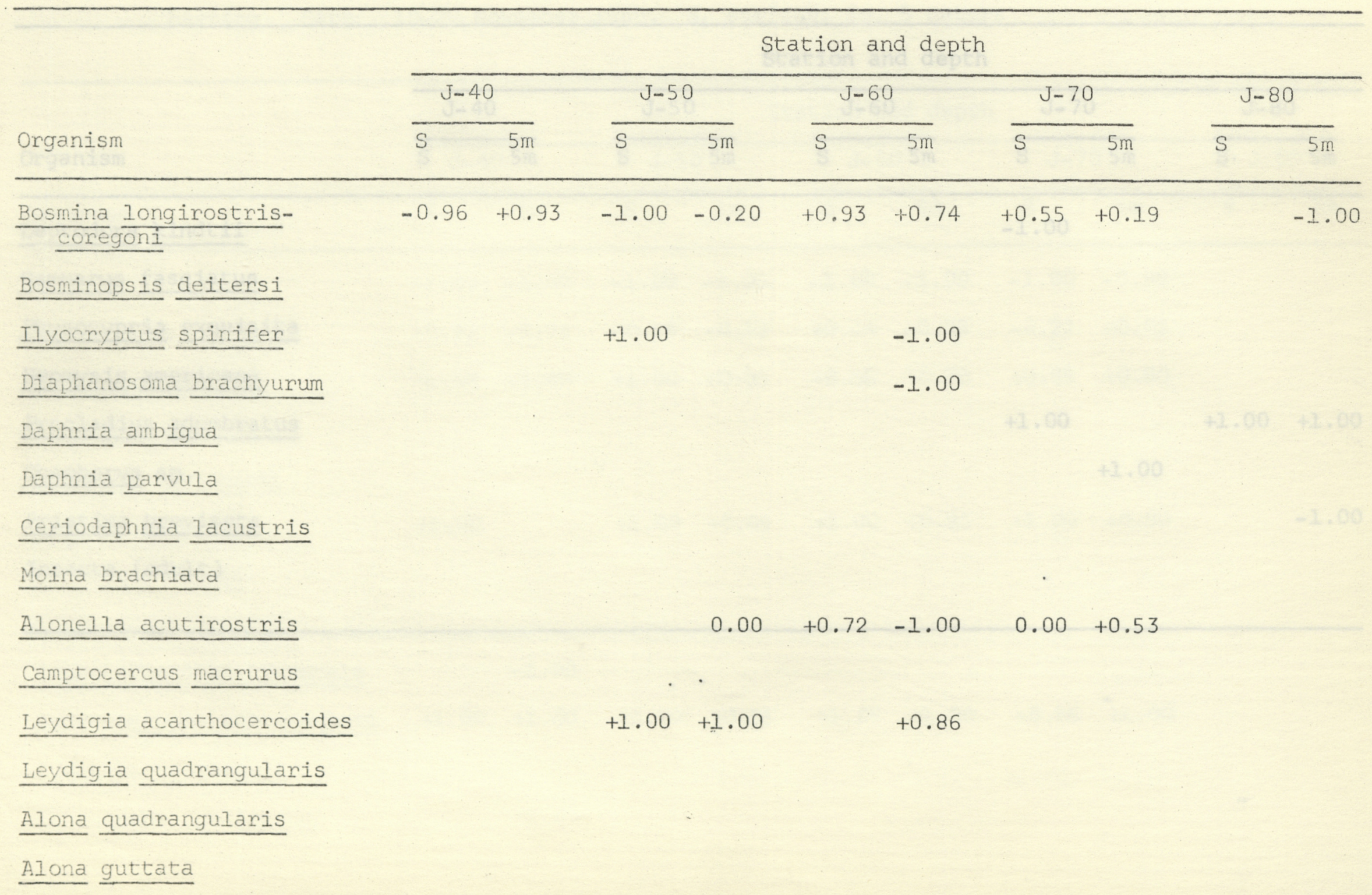


Table C5. (Continued).

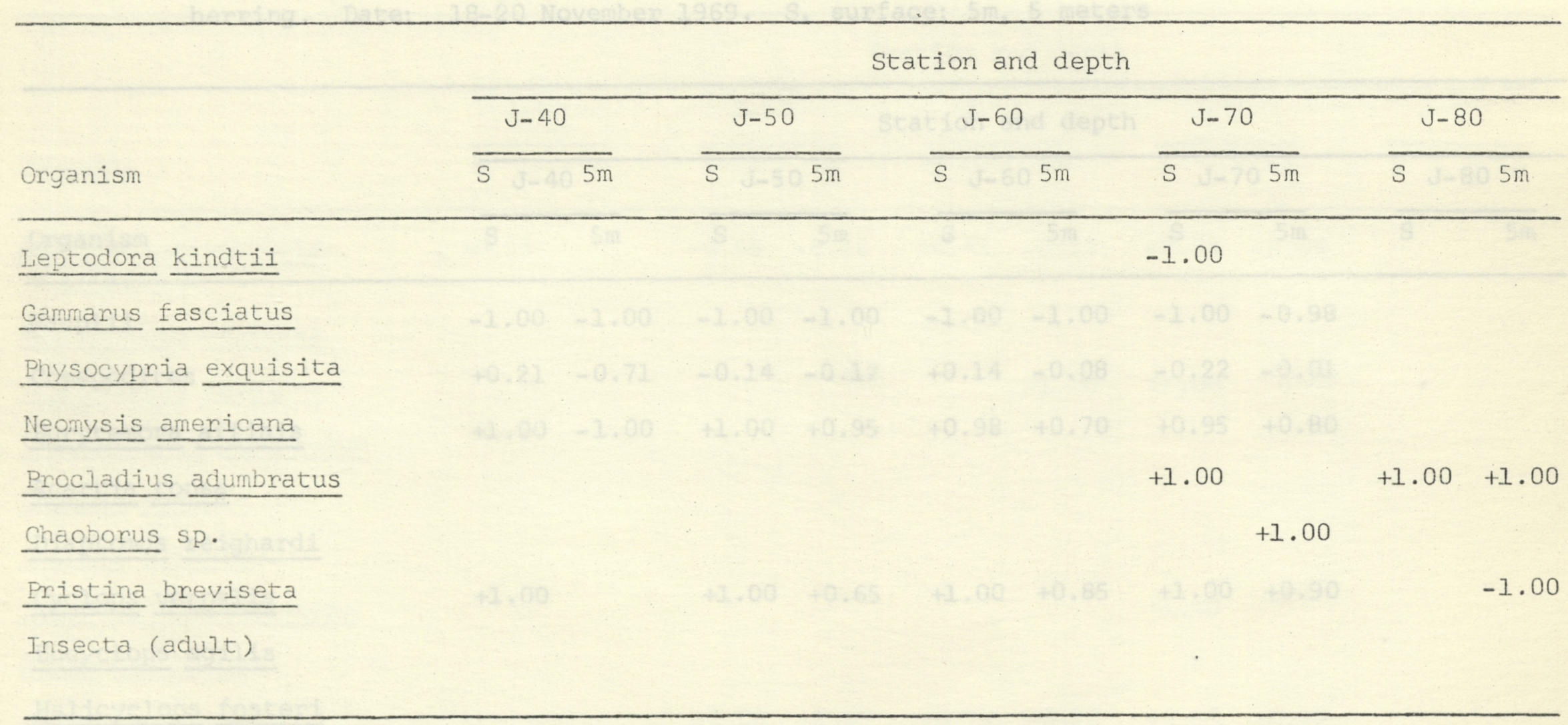


Table C6. Selection (Electivity of Ivlev, 1961) of zooplankton by young-of-the-year blueback herring. Date: 18-20 November 1969. S, surface; $5 \mathrm{~m}, 5$ meters

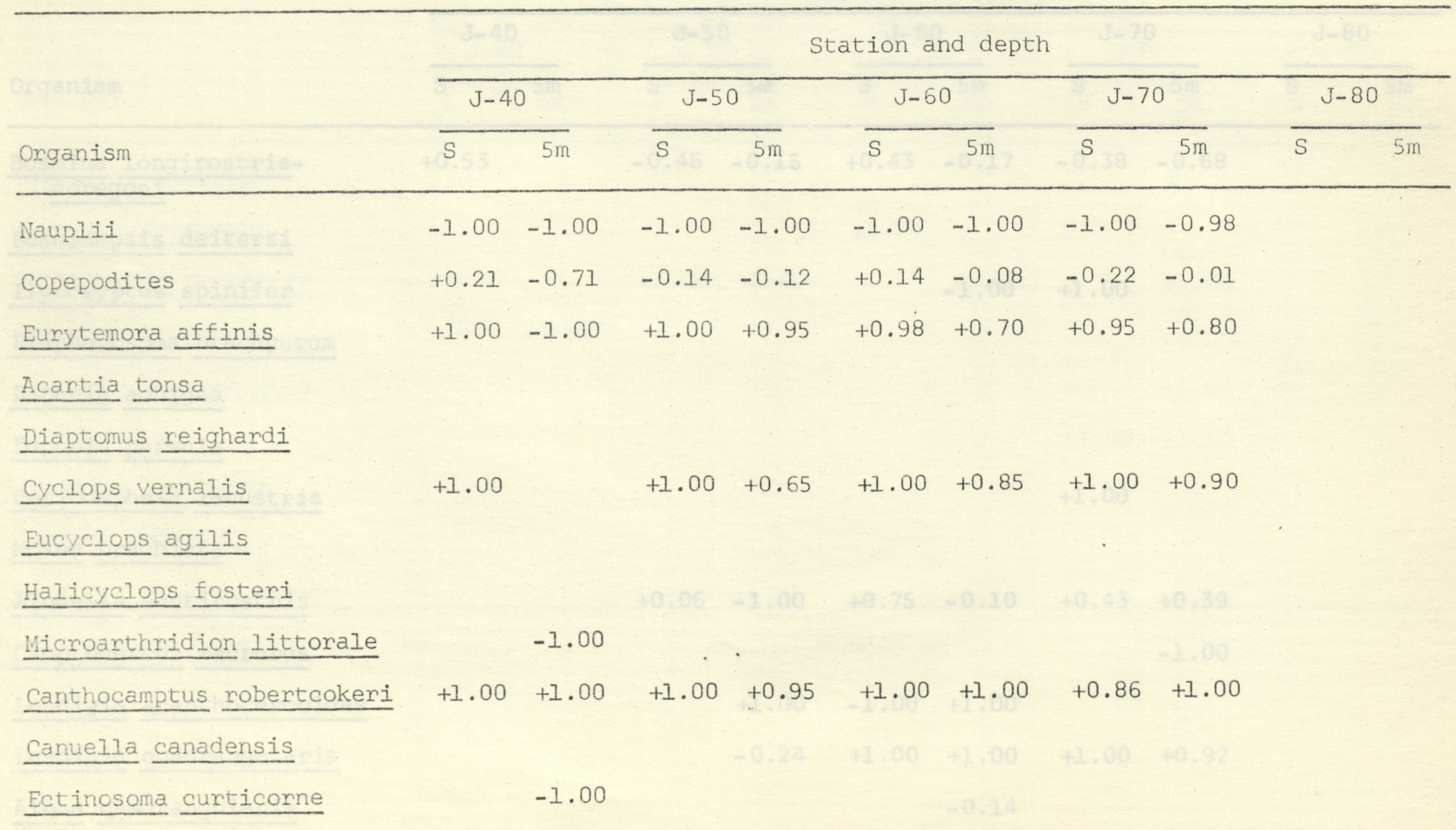




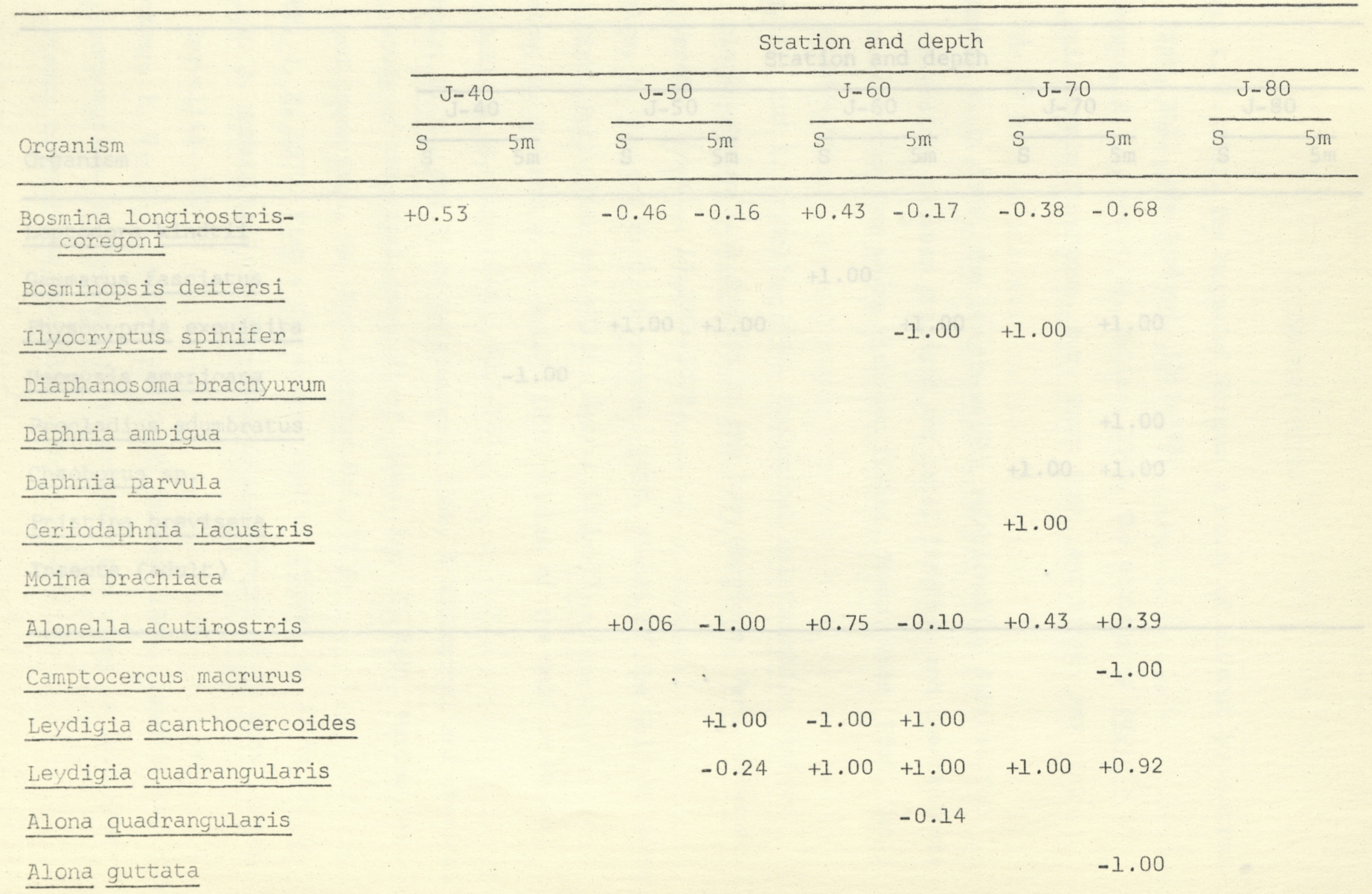


Table c6. (continued).

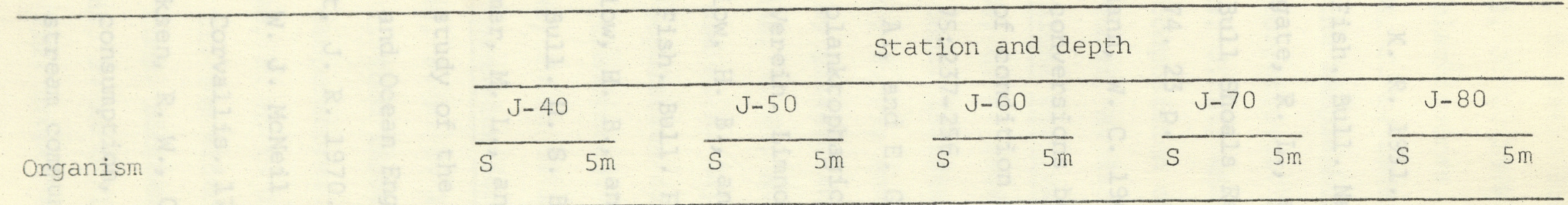

Leptodora kindtii

Gammarus fasciatus

Physocypria exquisita

Neomysis americana

Procladius adumbratus

Chaoborus sp.

Pristina breviseta

Insecta (adult)
$+1.00$

$+1.00+1.00+1.00+1.00$

$-1.00$

$+1.00$

$+1.00+1.00$ 


\section{LITERATURE CITED}

Allen, K. R. 1951. The Horokiwi Stream: a study of a trout population. Fish. Bull. New Zealand, 10:1-238.

Applegate, R. L., and J.W. Mullan. 1969. The ecology of Daphnia in

Bull Shoals Reservoir. Bur. Sport Fish. and Wildl. Res. Rep.,

74. $23 \mathrm{p}$.

Beckmann, W. C. 1948. The length-weight relationship, factors for conversions between standard and total lengths, and coefficients of condition for seven Michigan fishes. Trans. Amer. Fish. Soc., $75: 237-256$.

Berg, A., and E. Grimaldi. 1966. Ecological relationships between planktophagic fish species in the Lago Maggiore. Verh. Internat. Verein. Limnol., 16: 1065-1073.

Bigelow, H. B., and W. C. Schnoeder. 1953. Fishes of the Gulf of Maine. Fish. Bull. Fish and Wildl. Serv., 53:1-577.

Bigelow, H. B., and W. W. Welsh. 1925. Fishes of the Gulf of Maine.

Bu11. U. S. Bur. Fish., 40:1-567.

Brehmer, M. L., and S. O. Haltiwanger. 1966. A biologica.l and chemical study of the tidal James River. Spec. Rep. in Appl. Marine Scj. and Ocean Eng., Va. Inst. Marine Sci. 32 p.

Brett, J. R. 1970. Fish - the energy cost of living, p. 37 to 52. In W. J. McNeil (ed.). Marine aquiculture. Oregon State Univ. Press, Corvallis. $172 \mathrm{p}$.

Brocksen, R. W., G. E. Davis, and C. E. Warren. 1968. Competition, food consumption, and production of sculpins and trout in laboratory stream communities. J. Wildl. Manage., 32:51-75. 
Brody, S. 1945. Bioenergetics and growth. Reinhold, New. York. 1023 p. Brooks, J. L. 1968. The effects of prey size selection by lake planktivores. Syst. Zool., 17:273-291.

Brooks, J. I. 1969. Eutrophication and changes in the composition of the zooplankton, p. 236-255. In Eutrophication: causes, consequences, correctives. Nat. Acad. Sci. Publ. 1700. 661 p.

Brooks, J. L., and S. I. Dodson. 1965. Predation, body size, and composition of plankton. Science, 150:28-35.

Chittenden, M. E., Jr. 1972. Salinity tolerance of young blueback herring, Alosa aestivalis. Trans. Amer. Fish. Soc., 101:123-125.

Comita, G. W. 1964. The energy budget of Diaptomus siciloides, Iilljeborg. Verh. Internat. Verein. Iimnol., 15:646-653.

cramer, J. D., and G. R. Marzolf. 1970. Selective predation on zooplankton by gizzard shad. Trans. Amer. Fish. Soc., 99:320-332.

Cumins, K. W., R. C. Costa, R. E. Rowe, G. A. Moshiri,. R. M. Scanlon, and R. K. Zajdel. 1969. Ecological energetics of a natural population of the predaceous zooplankter Leptodora kindtii Focke (cladocera). Oikos, 20:189-223.

Davies, P. M. C. 1963. Food input and energy extraction efficiency in Carassius auratus. Nature, 198: 707.

Davies, P. M. C. 1964. The energy relations of Carassius auratus L. I. Food input and energy extraction efficiency at two experimental temperatures. Comp. Biochem. Physiol., 12:67-79.

Davies, P. M. C. 1966. The energy relations of Carassius auratus L. II. The effect of food, crowding and darkness on heat production. Comp. Biochem. Physiol., 17:983-995.

Davies, P. M. C. 1967. Energy relations of Carassius auratus L.

III. Growth and overall. energy balance. Comp. Biochem. Physiol., $23: 59-64$. 
Davis, J. R., and R. P. Cheek. 1966. Distribution, food habits, and growth of young clupeids, Cape River system, North Carolina. Unpub. $10 \mathrm{p}$.

Davis, G. E., and C. E. Warren. 1965. Trophic relations of sculpin in laboratory stream communities. J. Wildl. Manage., 29:846-87I. Dodson, S. I. 1970. Complementary feeding niches sustained by sizeselective predation. Limnol. and Ocean., 15:131-137. Englemann, M. D. 1961. The role of soil arthropods in the energetics of an old-field community. Ecol. Mono., 31: 221-238.

Englemann, M. D. 1966. Energetics, terrestrial field studies, and animal productivity, p. 73-115. In J. B. Craig (ed.). Advances in ecol. res. Vol. 3. Academic Press, N. Y. 324 p.

Gailbraith, M. G. 1967. Size-selective predation on Daphnia by rainbow trout and yellow perch. Trans. Amer. Fish. Soc., 96:1-10.

Gerking, S. D. 1952. The protein metabolism of sunfishes of different ages. Physiol. Zo81., 25:358-372.

Hildebrand, S. F., and W. C. Schroeder. 1928. Fishes of Chesapeake Bay. Bu11. U. S. Bur. Fish., 43:1-366.

Horton, P. A. 1961. The bionomics of brown trout in a Dartmoor stream. J. Anim. Ecol., 30:311-338.

Houde, E. D. 1967. Food of pelagic young of the walleye, Stizostedion vitreum vitreum, in Oneida Lake, New York. Trans. Amer. Fish. Soc., $96: 17-24$.

Hutchinson, B. P. 1971. The effect of fish predation on the zooplankton of ten Adirondack lakes, with particular reference to the alewife, Alosa pseudoharengus. Trans. Amer. Fish. Soc., 100:325-335.

Ivlev, V. S. 1945. The biological productivity of waters. Usp. Sovrem Biol., 19:98-120. (Fish. Res. Bd. Canada Transl. Ser. No. 394). 
Ivlev, V. S. 1961. Experimental ecology of the feeding of fishes.

(Transl. from Russian by D. Scott). Yale Univ. Press, New Haven. 302 p.

Johnson, W. E. 1961. Aspects of the ecology of a pelagic, zooplanktoneating fish. Verh. Internat. Verein. Limnol., 14:727-731.

Johnson, W. E. 1965. On mechanisms of self-regulation of population abundance in Oncorhynchus nerka. Mitt. Verh. Internat. Verein. Limnol., 13:66-87.

Juday, c. 1940. The annual energy budget of an inland lake. Ecology, $21: 438-450$.

King, D. L., and R. C. Ball. 1967. Comparative energetics of a polluted stream. Limnol. and Ocean., 12:27-33.

Kleiber, M. 1961. The fire of life. An introduction to animal energetics. John Wiley and Sons, Inc., New York. 454 p.

Laarman, P.W. 1969. Effects of a limited food supply on growth rates of coho salmon and steelhead trout. Trans. Amer. Fish. Soc., $98: 393-397$.

Lindeman, R. L. 1942. The trophic-dynamic aspect of ecology. Ecology, $23: 399-418$.

MacArthur, R., and R. Levins. 1964. Competition, habitat selection, and character displacement in a patchy environment. Proc. Nat. Acad. Sci., 51:1207-1210.

Mann, K. H. 1964. The pattern of energy flow in the fish and invertebrate fauna of the River Thames. Verh. Intemat. Verein. Limnol., 15: $485-495$.

Mann, K. H. 1965. Energy transformations by a population of fish in the River Thames. J. Anim. Ecol., 34:253-275. 
Mansueti, A. J., and J. D. Hardy. 1967: Development of fishes of the Chesapeake Bay region. Nat. Resources Inst., Univ. Maryland, Baltimore. 202 p.

Massmann, W. H. 1953. Relative abundance of young fishes in Virginia estuaries. Trans. 18th N. Amer. Wildl. Conf., P. 439-449. Massmann, W. H. 1963. Summer food of juvenile American shad in Virginia waters. Ches. Sci., 4:167-171.

Massmann, W. H., E. C. Ladd, and H. N. McCutcheon. 1952. A surface trawl for sampling young fishes in tidal rivers. Trans. 17 th N. Amer. Wildl. Conf., p. 386-392.

Morowitz, H. J. 1968. Energy Elow in biology. Academic Press, New York. $179 \mathrm{p}$

Odum, H. T. 1957. Trophic structure and productivity of Silver Springs, Florida. Ecol. Mono., 27:55-112.

Pandian, T.J. 1967a. Intake, digestion, absorption and conversion of food in the fishes Megalops cyprinoides and Ophiocephalus striatus. J. Marine Biol., 1:16-32.

Pandian, T. J. 1967b. Transformation of food in the fish Megalops cyprinoides. I. Influence of quality of food. J. Marine Biol., $1: 60-64$.

Phillipson, J. 1966. Ecological energetics. St. Martin's Press, New York. $57 \mathrm{p}$.

Reif, C. B., and D.W. Tappa. 1966. Selective predation: smelt and cladocerans in Harveys Lake. Limnol. and Ocean., 11:437-438.

Richman, S. 1958. The transformation of energy by Daphnia pulex. Ecol. Mono., 28:273-291.

Slobodkin, L. B. 1962. Energy in animal ecology, p. 69-101. In J. B. Craig (ed.). Advances in ecol. res. Vol. I. Academic Press, New York. 203 p. 
Smith, F. E. 1963. Population dynamics in Daphnia magna and a new model. for population growth. Ecology, 44:651-663.

Starostka, V. J., and R. L. Applegate. 1970. Food selectivity of bigmouth buffalo, Ictiobus cyprinellus, in Lake Poinsett, South Dakota. Trans. Amer. Fish. Soc., 99:571-576.

Teal, J. M. 1957. Community metabolism in a temperate cold spring. Ecol. Mono., 27:283-302.

Teal, J. M. 1962. Energy flow in the salt marsh ecosystem of Georgia. Ecology, 43:614-624.

U. S. Dept. Interior. 1969. Virginia water resources summary, August 1.969. Geological Survey. 4 p.

Walburg, C. H., and J. E. Sykes. 1957. Shad fishery of Chesapeake Bay with special emphasis on the fishery of Virginia. U.S. Dep. Int., Fish and Wildl. Serv., Res. Rep. 48. 26 p.

Ward, H. B., and G. C. Whipple. 1959. Fresh-water biology. John Wiley and Sons, Inc., New York. $1248 \mathrm{p}$.

Warren, C. E., and G. E. Davis. 1967. Laboratory studies on the feeding, bioenergetics, and growth of fish, p. 175-214. In S. D. Gerking (ed.). The biological basis of freshwater fish production. John Wiley and Sons, Inc., New York. 495 p. Wells, J. M., and J. E. Warinner. 1968. A reconding volumetric respirometer for aquatic animals. Limnol. and Ocean., 13:376-378. Wel1s, I. 1970. Effects of alewife predation on zooplankton populations in Lake Michigan. Limnol. and Ocean., 15:556-565. Winberg, G. G. 1956. Rate of metabolism and food requirements of fishes. Fish. Res. Bd. Canada, Trans1. Ser. No. 194. 202 p. Wissing, T. E. 1969. Energy transformations, food habits, and growth rates of young-of-the-year white bass, Morone chrysops, in Lake Mendota, Wisconsin. Unpub1. Ph.D. Dissertation, Univ. Wisconsin. 147 p. 


\section{RICHARD GREIG BURBIDGE}

Born in Philadelphia, Pennsylvania, July 10, 1941. Graduated from Central High School in Kalamazoo, Michigan, June 1959. B.A., Kalamazoo College, 1964. M.S., Michigan State University, 1967.

Entered the Department of Marine Science (Virginia Institute of Marine Science) of the University of Virginia as a graduate research assistant in February 1967. 